ADRIANE SOUSA DE SIQUEIRA

\title{
PEPTÍDEO AG73, DERIVADO DA LAMININA-111, INDUZ MIGRAÇÃO, INVASÃO E SECREÇÃO DE PROTEASES EM LINHAGEM CELULAR DERIVADA DE CARCINOMA EPIDERMÓIDE ORAL ATRAVÉS DE SINDECANA-1 E INTEGRINA $\beta 1$
}

Dissertação apresentada ao Programa de Pós-Graduação em Biologia Celular e Tecidual do Instituto de Ciências Biomédicas da Universidade de São Paulo, para obtenção do Título de Mestre em Ciências Biológicas.

São Paulo 
ADRIANE SOUSA DE SIQUEIRA

\section{PEPTÍDEO AG73, DERIVADO DA LAMININA-111, INDUZ MIGRAÇÃO, INVASÃO E SECREÇÃO DE PROTEASES EM LINHAGEM CELULAR DERIVADA DE CARCINOMA EPIDERMÓIDE ORAL ATRAVÉS DE SINDECANA-1 E INTEGRINA $\beta 1$}

Dissertação apresentada ao Programa de Pós-Graduação em Biologia Celular e Tecidual do Instituto de Ciências Biomédicas da Universidade de São Paulo, para obtenção do Título de Mestre em Ciências Biológicas.

Área de Concentração: Biologia Celular e Tecidual

Orientador: Prof. Dr. Ruy Gastaldoni Jaeger 
DADOS DE CATALOGAÇÃO NA PUBLICAÇÃO (CIP)

Serviço de Biblioteca e Informação Biomédica do

Instituto de Ciências Biomédicas da Universidade de São Paulo

(c) reprodução total

Siqueira, Adriane Sousa de.

Peptídeo AG73, derivado da laminina-111, induz migração, invasão e secreção de proteases em linhagem celular derivada de carcinoma epidermóide oral através de sindecana- 1 e integrina $\beta 1$ / Adriane Sousa de Siqueira. -- São Paulo, 2009.

Orientador: Ruy Gastaldoni Jaeger.

Dissertação (Mestrado) - Universidade de São Paulo. Instituto de Ciências Biomédicas. Departamento de Biologia Celular e do

Desenvolvimento. Área de concentração: Biologia Celular e Tecidual. Linha de pesquisa: Laminina e seus peptídeos bioativos influenciando o comportamento de tumores de glândulas salivares.

Versão do título para o inglês: Laminin-111-derived peptide AG73 induces migration, invasion and protease secretion in cell line derived from oral squamous cell carcinoma through syndecan- 1 and $\beta 1$ integrin.

Descritores: 1. Carcinoma epidermóide 2. Laminina 3. Metaloprotease de matriz 4. Peptídeo AG73 5. Sindecana-1 6 Integrina $\beta 1$ I. Jaeger, Ruy Gastaldoni II. Universidade de São Paulo. Instituto de Ciências Biomédicas. Programa de Pós Graduação em Biologia Celular e Tecidual III. Título. 
UNIVERSIDADE DE SÃO PAULO

INSTITUTO DE CIÊNCIAS BIOMÉDICAS

\begin{abstract}
Candidato(a):
Adriane Sousa de Siqueira.

Título da Dissertação: $\quad$ Peptídeo AG73, derivado da laminina-111, induz migração, invasão e secreção de proteases em linhagem celular derivada de carcinoma epidermóide oral através de sindecana-1 e integrina $\beta 1$.
\end{abstract}

Orientador(a):

Ruy Gastaldoni Jaeger.

A Comissão Julgadora dos trabalhos de Defesa da Dissertação de Mestrado, em sessão pública realizada a .........

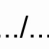

\title{
( ) Aprovado(a) \\ ( ) Reprovado(a)
}

\begin{tabular}{|c|c|}
\hline Examinador(a): & $\begin{array}{l}\text { Assinatura: } \\
\text { Nome: } \\
\text { Instituição: }\end{array}$ \\
\hline Examinador(a): & $\begin{array}{l}\text { Assinatura: } \\
\text { Nome: ........ } \\
\text { Instituição: }\end{array}$ \\
\hline Presidente: & $\begin{array}{l}\text { Assinatura: } \\
\text { Nome: ........ } \\
\text { Instituição: }\end{array}$ \\
\hline
\end{tabular}


UNIVERSIDADE DE SÃO PAULO

INSTITUTO DE CIÊNCIAS BIOMÉDICAS

Cidade Universitária "Armando de Salles Oliveira"

Av. Prof. Lineu Prestes, 2415 - CEP. 05508-000 São Paulo, SP - Brasil

3091-7438

e-mail: cep@icb.usp.br

Comissão de Ética em Pesquisa

CERTIFICADO DE ISENÇÃO

Certificamos que o Protocolo CEP-ICB N ${ }^{\circ} \mathbf{2 8 5}$, referente ao projeto intitulado: "Papel de peptídeos bioativos da laminina na migração e invasão de linhagens celulares derivadas de carcinoma epidermóide" sob a responsabilidade de Adriane Sousa de Siqueira, foi analisado na presente data pela CEEA - COMISSÃO DE ÉTICA EM EXPERIMENTAÇÃO ANIMAL e pela CEPSh - COMISSÃO DE ÉtiCA EM PESQUISA COM SERES HUMANOS, tendo sido deliberado que o referido projeto não envolve manipulação animal ou humana que justifique uma aprovação quanto aos princípios éticos exigidos por ambas as Comissões.

São Paulo, 19 de fevereiro de 2009.

Leximent

PROF. DR. WOTHAN TAVARES DE LIMA Coordenador da CEEA - ICB/USP

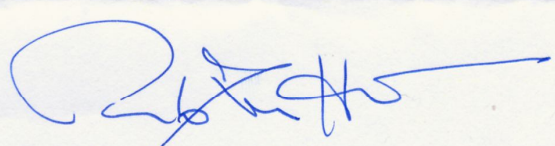

Prof. Dr, PAOLO M.A ZaNOTTO Vice-Coordenador da CEPsh - ICB/USP 
Dedico este trabalho à minha família, principal fonte do meu conhecimento. A meu pai Raimundo, que sempre acreditou em mim e me fez aprender que, se me esforçasse, poderia chegar aonde quisesse. À minha mãe Antônia, que me instruiu e me criou para o mundo, mas o fez com tanta dedicação e afeto que acabou sendo difícil ficar longe de casa. À Gisele, que apesar de ser minha irmã caçula é um grande exemplo de maturidade e sabedoria. E à tia Luci, por me ensinar o valor da amizade e do companheirismo. Obrigada a todos pelo apoio e pelo carinho. Mesmo à distância, vocês participaram de cada um dos dias dessa conquista. 


\section{AGRADECIMENTOS ESPECIAIS}

Ao Prof. Ruy Gastaldoni Jaeger, por ter me dado a oportunidade de trabalhar em seu laboratório, e por ter conduzido este trabalho com dedicação e competência. Obrigada pelo apoio e suporte, e por me mostrar que a base de todo conhecimento está no ato de pensar sobre aquilo que fazemos. Seus ensinamentos foram e são fundamentais para minha formação não só como profissional, mas como ser humano. 
Ao Prof. João de Jesus Viana Pinheiro, que desde a Iniciação Científica se mostrou não só um excelente orientador, mas um grande amigo. Você acreditou em mim e é um dos grandes responsáveis por eu estar aqui hoje. Ao me indicar para o Prof. Ruy Jaeger, você não só me deu uma oportunidade de fazer pós-graduação, mas me permitiu realizar um grande sonho. Agradeço também pela ajuda com os experimentos de imunohistoquímica e pela ajuda nas etapas finais de elaboração desse trabalho. Aprendi e continuo aprendendo muito com seus ensinamentos. 


\begin{abstract}
À Dra. Letícia Nogueira da Gama de Souza, que com muita boa vontade e paciência, me instruiu na arte de fazer experimentos. Obrigada por todo o tempo que você dedicou a mim, e também pela ajuda com os experimentos de RNA de interferência desse trabalho. Agradeço, mais ainda, pela sua amizade. Fora do laboratório, você foi uma grande companheira. Obrigada pelas horas de conversa, por sempre ter me acolhido em sua casa, e por fazer os fins de semana paulistanos passarem mais depressa. Você é alguém que sempre irei admirar pela inteligência e pela persistência.
\end{abstract}


Ao Thyago, que ano após ano me faz ter certeza de que é a pessoa mais especial que já conheci. Seu amor e seu companheirismo tornaram muito mais fácil minha vida longe de casa. Agradeço por ter sido sempre muito compreensivo e carinhoso, e por ter compartilhado das minhas decepções e vitórias. Sua ajuda, especialmente nas etapas finais, foi muito importante durante a elaboração desse trabalho. Obrigada por ser não só meu namorado, mas também meu melhor amigo. 


\section{AGRADECIMENTOS}

À Fundação de Amparo e Pesquisa do Estado de São Paulo (FAPESP), pelo suporte financeiro. A concessão de bolsa de mestrado e reserva técnica foi de extrema importância para a realização deste trabalho.

À Profa. Dra. Telma Zorn e sua equipe, por toda atenção e disponibilidade dispensadas ao nosso grupo. Obrigada pelo espaço cedido em seu laboratório para a realização de experimentos de cultura celular, e por também permitir o uso de alguns de seus equipamentos. Sua ajuda foi fundamental para a execução desse projeto.

À Profa. Dra. Gláucia Maria Machado-Santelli e seu grupo, pelo carinho e colaboração. Agradeço pelos equipamentos cedidos, trocas de reagentes e permissão para utilização da sala multi-usuário.

À Profa. Dra. Irene Yan e sua equipe, sempre muito atenciosos, que gentilmente permitiram a utilização dos equipamentos de seu laboratório.

Ao Prof. Jarbas Arruda Bauer, por tudo o que me ensinou durante a disciplina "Conceitos, métodos e diagnósticos em biologia tecidual". Obrigada por ser sempre muito prestativo, e por ter me contagiado com sua paixão pela Histologia.

À Profa. Dra. Patrícia Gama e Profa. Dra. Maria Inês Borella, pelas sugestões durante as aulas preparatórias para o curso de Difusão Científica. Gostaria ainda de parabenizar essa iniciativa, que é muito importante para uma melhor formação dos alunos da Pós-Graduação.

À Profa. Dra. Marinilce Santos e Profa. Dra. Edna Kimura, pela oportunidade de participar do plano PAE nas turmas de graduação de Odontologia e Medicina. Além do aprendizado, ser monitora dessas turmas me permitiu ter um contato mais próximo com a sala de aula. 
Aos Prof. Dr. Anselmo Moriscot, Prof. Dra. Alison Colquhoun e Prof. Dr. João Gustavo Amarante, pelas relevantes observações e sugestões feitas durante meu exame de qualificação.

À Dra. Vanessa Morais Freitas, pela inestimável colaboração neste trabalho. Agradeço pelas sugestões, pelo treinamento e pela paciência para responder minhas eternas dúvidas. Você é a cientista que eu quero ser um dia. Obrigada ainda pela amizade, pelo afeto, e por toda ajuda extra-laboratório que você sempre tem me dado.

Aos meus colegas de Laboratório: Camila, Elaine, Emerson, Karen, João, Letícia, Luciana, Milza, Renato, Raphael e Vanessa. Obrigada pela amizade e apoio. Trabalhar ao lado de todos vocês foi uma experiência incrível e também divertida. Camila, obrigada por ser tão prestativa e tão carinhosa. Elaine, agradeço pelo treinamento inicial e pelas orientações valiosas. Karen, apesar de toda sua teimosia, foi um prazer ser sua "tutora". Luciana, Milza e Emerson, obrigada pela ajuda e pela torcida. Renato e Raphael, agradeço pelo apoio técnico e pela amizade. Vocês todos fazem parte da minha família paulista!

Aos membros da Comissão de Pós-Graduação Profa. Dra. Dânia Hamassaki-Brito, Profa. Dra. Marinilce Santos, Profa. Dra. Marília Seelaender e Profa. Dra. Edna Kimura, obrigado pela busca por melhorias de nosso departamento. Agradeço também aos funcionários da secretaria, pela dedicação e atenção.

Aos meus amigos paraenses que de alguma maneira fizeram parte dessa história. Paula, Cibelle, Celina, Paulo, Bruno, Renata, Larissa e Netto, muito obrigada pelo apoio e pela amizade. As visitas e os encontros com alguns de vocês me ajudaram a matar um pouco das saudades que tenho da nossa terra.

Aos meus sogros, Ivanice e Geraldo, e à minha cunhada Camilla, que sempre me acolheram em seu ambiente familiar, e me deram todo suporte durante a redação desse trabalho. Obrigada pela hospitalidade e pelo carinho. 


\section{RESUMO}

SIQUEIRA, A.S. Peptídeo AG73, derivado da laminina-111, induz migração, invasão e secreção de proteases em linhagem celular derivada de carcinoma epidermóide oral através de sindecana-1 e integrina $\beta 1.2009 .106$ f. Dissertação (Mestrado em Biologia Celular e Tecidual) - Instituto de Ciências Biomédicas, Universidade de São Paulo, São Paulo, 2009.

O carcinona epidermóide é um prevalente tumor de cabeça e pescoço, relacionado a altas taxas de mortalidade. Seu crescimento e invasividade são estimulados por interações com matriz extracelular e membrana basal, a qual expressa laminina. Esta molécula contém sítios crípticos que estimulam atividades celulares e são expostos graças à ação de enzimas como as metaloproteinases da matriz (MMPs). Degradação da membrana basal mediada por MMPs é um evento crucial no desenvolvimento tumoral, e pode envolver clivagem da laminina e liberação de sítios crípticos capazes de influenciar o comportamento tumoral. Neste trabalho, verificamos se o peptídeo AG73, derivado da cadeia $\alpha 1$ da laminina-111, regula migração, invasão e atividade de protease em células derivadas de carcinoma epidermóide oral (OSCC). Imunohistoquímica e imunofluorescência demonstraram que cadeia $\alpha 1$ da laminina e MMP9 estão expressas in vivo e in vitro no carcinoma epidermóide. Ensaios de "ferida" e de migração demonstraram que AG73 promoveu aumento da atividade migratória de células OSCC. Esse peptídeo ainda estimulou invasão em ensaios em câmaras bipartites cobertas com Matrigel. Invasão é dependente de atividade de protease. Detectamos, através de zimografia, que células cultivadas sobre AG73 exibiram aumento dose-dependente de MMP9. Buscamos então receptores de AG73 que regulariam funções nesta linhagem. Células OSCC crescidas sobre AG73 exibiram colocalização de sindecana-1 e integrina $\beta 1$, e silenciamento desses receptores com RNA de interferência promoveu diminuição das atividades migratória e invasiva induzidas por AG73 em células OSCC. Nossos resultados sugerem que sindecana-1 e integrina $\beta 1$ podem ser ativadas por AG73 e transduzir sinais que regulam migração, invasão e produção de MMPs em células OSCC.

Palavras-chave: Carcinoma epidermóide. Matriz extracelular. Laminina. Metaloproteinases da matriz. Sindecanas. Integrinas. 


\begin{abstract}
SIQUEIRA, A.S. Laminin-111-derived peptide AG73 regulates migration, invasion and protease activity of cell line derived from oral squamous cell carcinoma through syndecan-1 and $\boldsymbol{\beta} 1$ integrin. 2009. $106 \mathrm{f}$. Master Thesis (Biologia Celular e Tecidual) - Instituto de Ciências Biomédicas, Universidade de São Paulo, São Paulo, 2009.

Oral squamous cell carcinoma is a prevalent head and neck tumor, related to high mortality rates. Its growth and invasiveness is stimulated by interactions with extracellular matrix and basement membrane, which expresses laminin. This molecule regulates tumor biology and harbors cryptic sites with important roles upon release by proteolytic enzymes such as matrix metalloproteinases (MMPs). MMPmediated breakdown of basement membrane is a critical step in tumor progression that involves laminin cleavage and release of peptides, which may influence carcinoma's behavior. Here we studied the role played by AG73 (RKRLQVQLSIRT, $\alpha 1$ chain) on migration, invasion and protease activity of a cell line (OSCC) from oral squamous cell carcinoma. Immunohistochemistry and immunofluorescence showed that laminin $\alpha 1$ chain and MMP9 are expressed in oral squamous cell carcinoma cells in vivo and in vitro. AG73 increased migratory activity of OSCC cells, as shown by monolayer wound assay and migration assay. This peptide also stimulated cell invasion in chemotaxis chambers coated with Matrigel. Invasion depends on protease activity. OSCC cells cultured on AG73 showed a dose-dependent increase of MMP9 secretion, detected by zymography. We searched for AG73 receptors regulating activities in this cell line. OSCC cells grown on AG73 exhibited colocalization of syndecan-1 and $\beta 1$ integrin, and. siRNA knockdown of these receptors decreased $A G 73-d e p e n d e n t$ migration and invasion. Our results suggest that syndecan-1 and $\beta 1$ integrin signaling downstream of AG73 regulate migration, invasion and MMP production by OSCC cells.
\end{abstract}

Keywords: Squamous cell carcinoma. Extracellular matrix. Laminin. Matrix Metalloproteinases. Syndecans. Integrins. 


\section{LISTA DE ILUSTRAÇÕES}

Figura 5.1 - Cadeia $\alpha 1$ da laminina-111 e MMP9 estão expressas em carcinoma

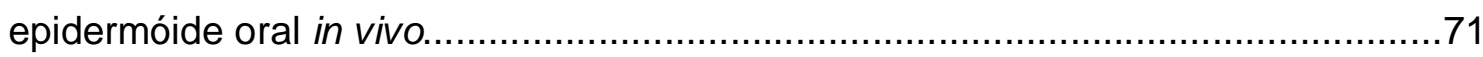

Figura 5.2 - Cadeia $\alpha 1$ da laminina-111 e MMP9 estão expressas em carcinoma

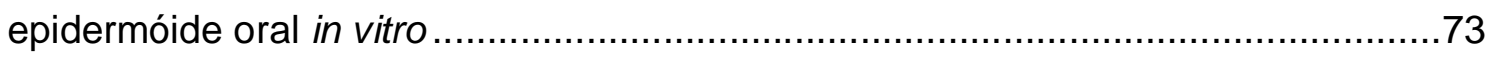

Figura 5.3 - AG73 induz migração em células OSCC...........................................75

Figura 5.4 - AG73 aumenta invasão e atividade de MMP9 em células OSCC …......77

Figura 5.5 - Sindecana-1 e integrina $\beta 1$ estão colocalizadas em células OSCC na

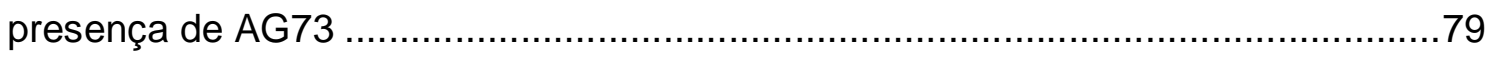

Figura 5.6 - Silenciamento de sindecana- 1 e integrina $\beta 1$ em células OSCC mostra que esses receptores regulam migração e invasão induzidas por AG73 ..................81 


\section{LISTA DE ABREVIATURAS E SIGLAS}

AEBSF do inglês "aminoethyl benzenesulfonyl fluoride", traduzido como fluoreto de aminoetil benzenosulfonil, é um inibidor de serina protease

AG73 sequência dos aminoácidos RKRLQVQLSIRT (arginina-lisina-argininaleucina-glicina-valina-glicina-leucina-serina-isoleucina-argininatreonina)

BSA do inglês "Bovine Serum Albumine" traduzido como albumina sérica bovina

${ }^{\circ} \mathrm{C} \quad$ graus Celsius

$\mathrm{Ca}^{2+} \quad$ íon cálcio

C16 sequência dos aminoácidos KAFDITYVRLKF (lisina-asparaginafenilalanina-ác. aspártico-isoleucina-treonina-tirosina-valina-argininaleucina-lisina- fenilalanina)

$\mathrm{cm}^{2} \quad$ centímetros quadrados

$\mathrm{CO}_{2} \quad$ gás carbônico

DMEM do inglês "Dulbecco's Modified Eagles' Medium" traduzido como meio de Eagle modificado por Dulbecco

DMSO di-metil sulfóxido

EDTA do inglês "ethylenediamine-tetra acetic acid" traduzido como ácido etilenodiamino tetra acético

EGF do inglês "epidermal growth receptor", traduzido como fator de crescimento epidermal; corresponde à sequência de aminoácidos ácido glutâmico-glicina-fenilalanina (Glu-Gly-Phe)

ERK do inglês "extracellular response kinase", traduzida como quinase de resposta extracelular 


\begin{tabular}{|c|c|}
\hline Fig. & Figura \\
\hline g & gravidade \\
\hline hs & horas \\
\hline HSG & $\begin{array}{l}\text { do inglês "human submandibular gland", traduzido como glândula } \\
\text { submandibular humana }\end{array}$ \\
\hline INCA & Instituto Nacional do Câncer \\
\hline $\mathrm{kDa}$ & kilodalton \\
\hline M & molar \\
\hline $\mathrm{mM}$ & milimolar \\
\hline$\mu \mathrm{M}$ & micromolar \\
\hline $\mathrm{Mg}^{2+}$ & íon magnésio \\
\hline $\mathrm{mg}$ & miligramas \\
\hline$\mu \mathrm{g}$ & microgramas \\
\hline$\mu \mathrm{g} / \mathrm{ml}$ & microgramas por mililitros \\
\hline $\min$. & minutos \\
\hline $\mathrm{ml}$ & mililitro \\
\hline $\mathrm{mm}$ & milímetro \\
\hline $\mathrm{mM}$ & milimolar \\
\hline MEC & matriz extracelular \\
\hline \multirow[t]{2}{*}{ MMPs } & do inglês "matrix metalloproteinases" \\
\hline & metaloproteinases da matriz \\
\hline $\mathrm{VaCl}$ & cloreto de sódio \\
\hline
\end{tabular}


$\mathrm{Na}_{2} \mathrm{HPO}_{4} \quad$ fosfato de sódio

NIDCR do inglês "National Institute of Dental and Craniofacial Research

$\mathrm{NIH}$ do inglês "National Institutes of Health

nm nanômetro

OMS Organização Mundial de Saúde

PBS do inglês "phosphate-buffered saline", traduzido como tampão fosfatosalina

pH cologarítmo da concentração hidrogeniônica de uma solução (potencial hidrogeniônico)

PMSF do inglês "phenylmethylsulphonyl fluoride", traduzido como fluoreto de fenilmetilsulfonil, é um inibidor de serina protease

SDS-PAGE do inglês "sodium dodecyl sulfate polyacrylamide gel electrophoresis" eletroforese de gel de poliacrilamida, tendo como agente denaturante sulfato dodecil sódico

SFB soro fetal bovino

TBS do inglês "Tris-buffered saline", traduzido como tampão tris-salina

YIGSR sequência dos aminoácidos (tirosina-isoleucina-glicina-serina-arginina) 


\section{LISTA DE SÍMBOLOS}

$\begin{array}{ll}\alpha & \text { alfa } \\ \beta & \text { beta } \\ \gamma & \\ & \text { gama }\end{array}$




\section{SUMÁRIO}

1 INTRODUÇÃO

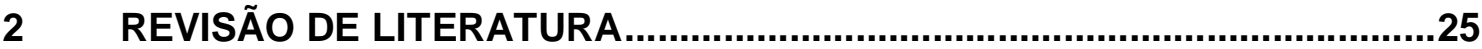

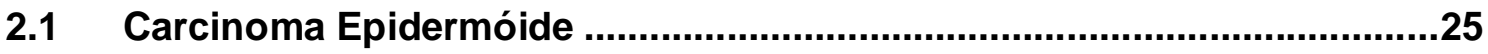

2.2 Matriz Extracelular e Membrana Basal ..................................................30

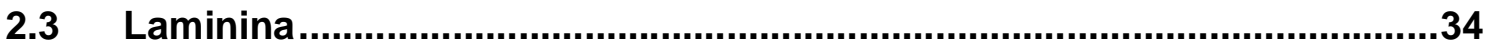

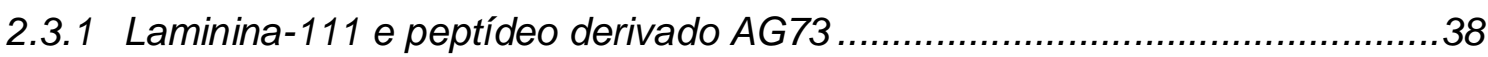

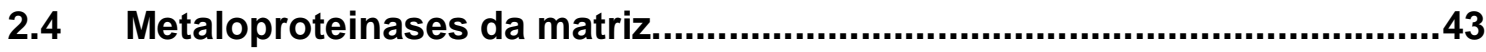

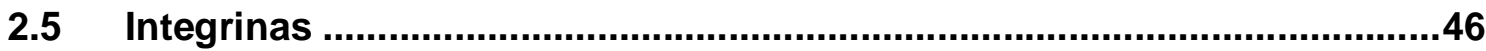

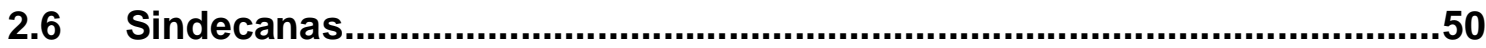

3 PROPOSIÇÃO

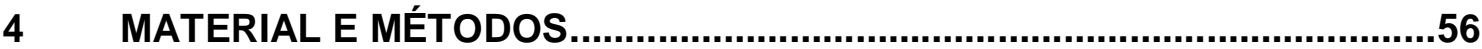

4.1 Detecção da cadeia $\alpha 1$ da laminina e MMP9 in vivo e in vitro em

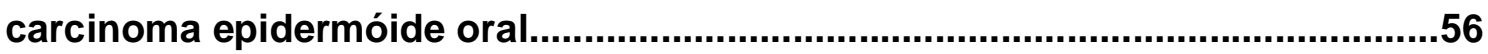

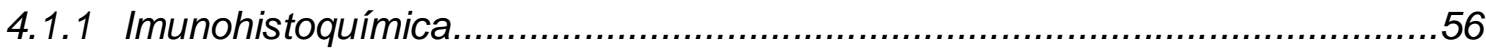

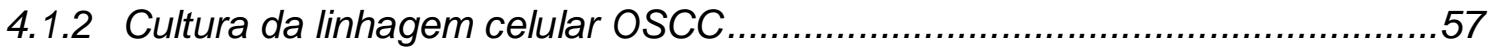

4.1.3 Imunofluorescência para detecção da cadeia $\alpha 1$ da laminina ........................57

4.1.4 Imunofluorescência para deteç̧ão de MMP9............................................58

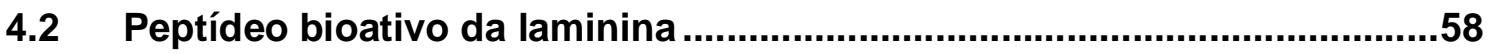

4.3 Papel do peptídeo AG73 na atividade migratória de células OSCC.........58

4.3.1 Ensaio de "ferida" em monocamada..........................................................58

4.3.2 Ensaio de migração em sistema de câmaras bipartites...............................59

4.4 Papel do peptídeo AG73 na atividade invasiva de células OSCC ............60

4.4.1 Ensaio de invasão em câmaras bipartites ..............................................60

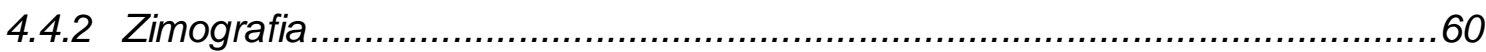

4.5 Estudo de receptores envolvidos nas atividades mediadas por AG73 em

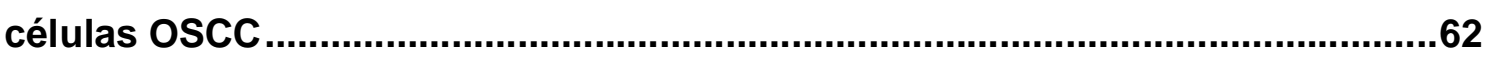

4.5.1 Colocalização dos receptores sindecana-1 e integrina $\beta 1$..........................62

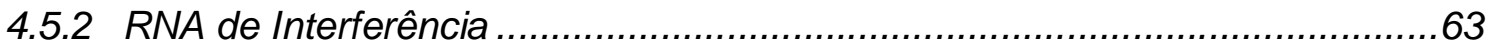

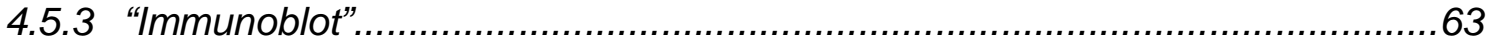

4.5.4 Ensaio de migração (células silenciadas para sindecana-1 e integrina $\beta 1$ )...64

4.5.5 Ensaio de invasão (células silenciadas para sindecana-1 e integrina $\beta 1$ )......65 
4.6 Análise Estatística .............................................................................65

$5 \quad$ RESULTADOS ......................................................................................66

5.1 Carcinoma epidermóide oral expressam a cadeia $\alpha 1$ da laminina e MMP9 in vivo e in vitro.......................................................................................................66

5.2 peptídeo AG73 influencia atividade migratória de células OSCC ........66

5.3 Peptídeo AG73 influencia atividade de invasão e secreção de MMPs em células OSCC.......................................................................................................67

5.4 Sindecana-1 e integrina $\beta 1$ participam dos processos de migração e invasão induzidos por AG73 em células OSCC....................................................68

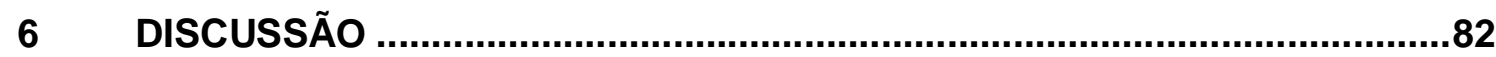

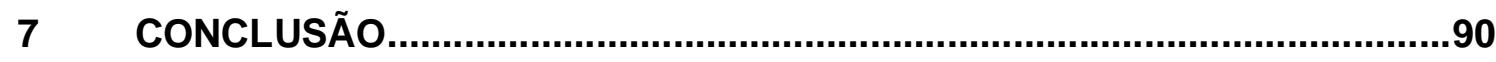

REFERÊNCIAS...........................................................................................91 


\section{INTRODUÇÃO}

O carcinoma epidermóide corresponde a mais de $94 \%$ das neoplasias malignas que afetam a cavidade oral (EPSTEIN, 2003; NEVILLE et al., 2004), e sua incidência constitui um grande problema na área de saúde, especialmente em países subdesenvolvidos (MEHROTRA e YADAV, 2006). Mesmo com grandes avanços nos métodos de diagnóstico e tratamento, a taxa de sobrevida de pacientes com carcinoma epidermóide oral em cinco anos é de 50\%, percentual considerado baixo quando comparado a outras neoplasias malignas (EPSTEIN, 2003; MEHROTRA e YADAV, 2006). Alterações celulares genéticas relacionadas ao desenvolvimento do carcinoma epidermóide oral possuem como principais fatores etiológicos o consumo de tabaco e bebidas alcoólicas (MASHBERG e SAMIT, 1989; BOYLE et al., 1990; MASHBERG et al., 1993; FRANCESCHI et al., 1994; SILVERMAN e SHILLITOE, 1998; NEVILLE e DAY, 2002; EPSTEIN, 2003)

O microambiente relacionado ao carcinoma epidermóide não é constituído apenas pelo componente maligno epitelial, mas também por estroma circundante. Assim, seu crescimento e progressão para carcinoma invasivo requerem interação das células tumorais com outros tecidos e com a matriz extracelular (MEHROTRA e YADAV, 2006; ZIOBER et al., 2006). A matriz extracelular é uma rede tridimensional complexa que oferece suporte estrutural e funciona como fonte de instruções para as células (SCHENK e QUARANTA, 2003; MINER e YURCHENCO, 2004). Em certos tecidos, como o epitélio, as células formam uma camada fina e flexível de matriz altamente especializada, a membrana basal, que participa dos processos de adesão, migração, crescimento e diferenciação celulares, e é essencial para a formação e manutenção de tecidos tanto nos estágios iniciais de desenvolvimento quanto na fase adulta. Componentes estruturais da membrana basal incluem lamininas, colágeno tipo IV, nidogênio e proteoglicanas (MINER e YURCHENCO, 2004; YURCHENCO et al., 2004; SUZUKI et al., 2005; YOKOYAMA et al., 2005; ZIOBER et al., 2006).

As lamininas são glicoproteínas heterotriméricas compostas por 3 subunidades polipeptídicas ( $\alpha, \beta$ e $\gamma$ ). Essas moléculas, proeminentemente expressas na membrana basal, promovem várias atividades biológicas como adesão, migração, proliferação, diferenciação e crescimento (WILSON et al., 1999; COLOGNATO e YURCHENCO, 2000; SUZUKI et al., 2003; MINER e YURCHENCO, 
2004; YURCHENCO e WADSWORTH, 2004; AUMAILLEY et al., 2005; YOKOYAMA et al., 2005). Assim como outras moléculas da matriz extracelular, lamininas possuem domínios crípticos escondidos em sua estrutura íntegra, os quais são expostos principalmente por proteólise. Esse processo pode dar origem a fragmentos e peptídeos bioativos, capazes de induzir funções biológicas tanto em células normais quanto neoplásicas (FAISAL KHAN et al., 2002; SCHENK e QUARANTA, 2003; MOTT e WERB, 2004).

Processamento proteolítico da matriz extracelular é um evento crítico na progressão de neoplasias malignas. Esse processo pode ser mediado por metaloproteinases da matriz (MMPs), família de enzimas que degrada todos os componentes da matriz e modula sua função (THOMAS et al., 1999; MOTT e WERB, 2004). Degradação da membrana basal mediada por MMPs pode promover liberação de peptídeos bioativos capazes de induzir motilidade e proliferação de células neoplásicas (GHOSH e STACK, 2000; ZIOBER et al., 2006).

Os efeitos biológicos de alguns domínios crípticos da laminina vem sendo extensivamente descritos (NOMIZU et al., 1992; NOMIZU et al., 1995; NOMIZU et al., 1997; HOFFMAN et al., 1998; NOMIZU et al., 1998; GHOSH e STACK, 2000; NOMIZU et al., 2000; HOFFMAN et al., 2001; NOMIZU et al., 2001; PONCE et al., 2001; ZIOBER et al., 2006). Em nosso laboratório, estudamos o papel da laminina111 (antiga laminina-1) e seus peptídeos em tumores de glândulas salivares (JAEGER et al., 1997; FRANCA et al., 2001; FREITAS e JAEGER, 2002; CAPUANO e JAEGER, 2004; FREITAS et al., 2004; OLIVEIRA, 2004; FREITAS et al., 2007; MORAIS FREITAS et al., 2007; GAMA-DE-SOUZA, 2008; GAMA-DE-SOUZA et al., 2008). Já demonstramos que o peptídeo YIGSR (cadeia $\beta 1$ ) promoveu aumento na taxa de migração celular (MORAIS FREITAS et al., 2007), e que SIKVAV (cadeia a1) está relacionado a diferenciação celular e secreção de proteases em linhagem celular derivada de carcinoma adenóide cístico (FREITAS e JAEGER, 2002; FREITAS et al., 2004; FREITAS et al., 2007).

Outro peptídeo que regula atividades biológicas em diferentes células e sistemas é AG73 (RKRLQVQLSIRT, domínio LG4 da cadeia a1) (HOFFMAN et al., 1998; HOFFMAN et al., 2001; ENGBRING et al., 2002; ENGBRING et al., 2008; GAMA-DE-SOUZA et al., 2008). A ação desse peptídeo parece ser bastante relevante em biologia tumoral, e já foi relacionada a metástases no fígado e de 
células de carcinoma de ovário, bem como a aumento de colonização pulmonar de células de melanoma (SONG et al., 1997; KIM et al., 1998; HOSOKAWA et al., 1999; YOSHIDA et al., 2001). AG73 também é um potente promotor de angiogênese (MOCHIZUKI et al., 2003), e já foi proposto como substância terapêtica para regeneração tecidual (MOCHIZUKI et al., 2003; IKEMOTO et al., 2006). Todas essas evidências sugerem que AG73 pode apresentar diferentes papéis na promoção de crescimento tumoral e metástase. Anteriormente, dados de nosso laboratório mostraram que AG73 regula morfologia, adesão e atividade de protease em linhagem celular derivada de carcinoma adenóide cístico. No entanto, a ação desse peptídeo no carcinoma epidermóide oral ainda não foi estudada.

Neste trabalho, verificamos os efeitos do peptídeo AG73 na migração, invasão, e secreção de proteases em linhagem celular derivada de carcinoma epidermóide oral humano (células OSCC). Analisamos também possíveis receptores relacionados às atividades biológicas induzidas por AG73 em células OSCC. 


\section{REVISÃO DE LITERATURA}

Na revisão de literatura abordaremos os seguintes temas relacionados a esta dissertação: 1) Carcinoma epidermóide, neoplasia maligna que deu origem à linhagem celular utilizada nesse estudo; 2) Conceitos básicos sobre matriz extracelular e membrana basal, com destaque para laminina e suas atividades biológicas; 3) Laminina-111 e peptídeo derivado AG73, objeto de estudo desse trabalho; 4) Metaloproteinases da matriz, enzimas fundamentais para o processo de invasão celular; 5) Integrinas, receptores de proteínas da matriz extracelular e 6) Sindecanas, co-receptores de proteínas da matriz extracelular.

\subsection{Carcinoma Epidermóide}

Os tumores de cabeça e pescoço correspondem a mais de $5 \%$ de todas as neoplasias malignas que acometem o ser humano, sendo a cavidade oral a região mais afetada (LANDIS et al., 1999; EPSTEIN, 2003). De acordo com a Organização Mundial de Saúde (OMS, 2008), os tumores da cavidade oral são o sétimo tipo de câncer mais comum entre os homens e o décimo segundo entre as mulheres, provocando cerca de 400.000 mortes por ano no mundo inteiro.

Os países subdesenvolvidos são os mais afetados por essa modalidade de câncer. Na Índia, os tumores bucais chegam a representar a segunda maior causa de mortalidade (OMS, 2008). No Brasil, a cavidade oral é o sétimo local mais acometido por neoplasias malignas, com estimativa de 14.160 novos casos para o ano de 2008. Nos homens, representa o quinto tumor maligno mais prevalente, enquanto nas mulheres é o sétimo. As regiões Sul e Sudeste concentram o maior número de casos (INCA, 2007).

Cerca de $94 \%$ de todas as malignidades da cavidade oral são representadas pelo carcinoma epidermóide, também denominado carcinoma de células escamosas (EPSTEIN, 2003; NEVILLE et al., 2004). Esse tumor se desenvolve a partir de alterações malignas do epitélio que reveste as superfícies da cavidade oral, e corresponde a nove em cada dez casos de neoplasias malignas bucais (SILVERMAN e SHILLITOE, 1998). 
Aproximadamente $95 \%$ dos casos de carcinoma epidermóide oral acometem indivíduos com mais de 40 anos, e a idade média de diagnóstico da doença é de 60 anos (SILVERMAN e SHILLITOE, 1998; NEVILLE e DAY, 2002). Esta incidência relacionada a idades avançadas sugere que são necessárias ações prolongadas de agentes carcinogênicos para ocasionar transformação maligna em células epiteliais (EPSTEIN, 2003).

O principal fator etiológico relacionado ao carcinoma epidermóide oral é o uso do tabaco. Porém, pouco se sabe sobre os mecanismos de transformação maligna das células epiteliais relacionados a essa substância (MASHBERG e SAMIT, 1989; BOYLE et al., 1990; SILVERMAN e SHILLITOE, 1998). Estudos epidemiológicos mostram que o risco de desenvolver carcinoma oral é de cinco a nove vezes maior em fumantes do que em não fumantes, e que esse risco pode ser até dezessete vezes maior para fumantes que consomem 80 ou mais cigarros por dia (MASHBERG et al., 1993; ANDRE et al., 1995; LEWIN et al., 1998). Entre 50\% a $80 \%$ das pessoas com carcinoma oral são fumantes (SILVERMAN et al., 1983; NEVILLE e DAY, 2002), sendo que cachimbos e charutos acarretam maiores riscos de causar neoplasias do que o cigarro comum (NEVILLE et al., 2004).

Apesar de a maioria das pesquisas relacionadas ao carcinoma epidermóide oral serem direcionados ao uso de cigarros, o "tabaco sem fumaça" também está vinculado ao surgimento de tumores (SQUIER, 1988; WINN, 1988; CURADO e HASHIBE, 2009). Estudos demonstram que pessoas que possuem hábito crônico de inalar tabaco apresentam risco quatro vezes maior de desenvolver carcinoma oral (WINN et al., 1981). Além do mais, a maior parte dos tumores orais em pacientes que consomem tabaco mascado, ou rapé, surge no local em que essa substância é colocada na boca. Todavia, o "tabaco sem fumaça" parece estar associado com risco muito menor de formação de neoplasias que cigarros, cachimbos e charutos (BOUQUOT e MECKSTROTH, 1998).

O consumo de bebidas alcoólicas também é considerado um importante fator etiológico do carcinoma epidermóide (MASHBERG et al., 1981; FRANCESCHI et al., 1994). O metabolismo do álcool no organismo gera como metabólito o acetaldeído, composto capaz de estimular produção de radicais livres e gerar danos ao DNA (BOUCHARDY et al., 2000; INAGAKI et al., 2003). Autores como Mashberg e colaboradores (1981) acreditam que bebidas alcoólicas devem ser consideradas como potentes agentes carcinogênicos. No entanto, outros pesquisadores 
(EPSTEIN, 2003; NEVILLE et al., 2004) sugerem que o álcool por si só não é capaz de gerar transformações malignas em células epiteliais. Para esses autores, o papel do álcool na carcinogênese está relacionado a sua ação sinérgica com substâncias, como o tabaco. Um estudo demonstrou que fumantes que consomem bebidas alcoólicas possuem maior concentração de acetaldeído na saliva, sugerindo que os efeitos nocivos da interação entre álcool e tabaco podem estar vinculados, em parte, a maior quantidade de acetaldeído na saliva (SALASPURO e SALASPURO, 2004). Além do mais, o álcool promove desidratação e aumento da permeabilidade da mucosa, deixando as células mais vulneráveis a agentes carcinogênicos do tabaco (PELUCCHI et al., 2008; CURADO e HASHIBE, 2009).

Evidências recentes sugerem que o papiloma vírus humano (HPV) pode estar associado com alguns tumores orais e orofaríngeos (SUGERMAN e SHILLITOE, 1997; GILLISON e SHAH, 2001; MORK et al., 2001). Os vírus HPV-16 e HPV-18 já foram detectados em $14 \%$ a $22 \%$ dos carcinomas orais (SUGERMAN e SHILLITOE, 1997), e infecções por esses vírus parecem funcionar como carcinógenos em indivíduos que não fumam nem consomem bebidas alcoólicas (GILLISON e SHAH, 2001). Deficiências nutricionais ligadas a baixo consumo de frutas e vegetais podem também estar relacionadas a risco aumentado de desenvolver câncer (WINN, 1995; NEVILLE et al., 2004), e exposição crônica a raios solares está associada ao surgimento de carcinomas no vermelhão do lábio (WINN, 1995; NEVILLE e DAY, 2002; NEVILLE et al., 2004).

Algumas pesquisas apontam que líquen plano oral pode estar associado com aumento do risco de câncer, apesar de essa associação ainda ser questionada (BARNARD et al., 1993; EISENBERG, 2000). Imunossupressão também parece predispor a um aumento de incidência dessa doença, já que carcinomas foram observados em transplantados renais que fizeram uso de medicamentos imunossupressores (DE VISSCHER et al., 1997) e em indivíduos portadores de AIDS (FLAITZ et al., 1995).

Carcinoma epidermóide oral invasivo é normalmente precedido pelo surgimento de lesões pré-malignas clinicamente identificáveis. Essas lesões costumam se apresentar sob a forma de placas brancas ou vermelhas, conhecidas respectivamente como leucoplasia e eritroplasia (NEVILLE e DAY, 2002). À medida que o carcinoma se desenvolve, surgem ulcerações superficiais da mucosa que não cicatrizam. Com o passar do tempo, a lesão pode transformar-se em uma massa 
exofítica com superfície papilar, ou apresentar padrão de crescimento endofítico caracterizado por superfície ulcerada com bordas elevadas (SILVERMAN et al., 1998; NEVILLE et al., 2004). Sinais e sintomas relacionados a estágios avançados incluem sangramentos, perda de dentes, dificuldade para usar dentaduras, disartria, dores e dificuldades de deglutição (NEVILLE e DAY, 2002).

O sítio da cavidade oral mais acometido pelo carcinoma epidermóide é a língua, com $40 \%$ dos casos, seguida pelo assoalho de boca (MASHBERG e SAMIT, 1989; SILVERMAN et al., 1998; NEVILLE e DAY, 2002; NEVILLE et al., 2004). Essas duas regiões, com extensão lateral para palato mole e tonsila, constituem uma área em forma de ferradura que apresenta maior risco para o desenvolvimento de tumores. Nessa área, os carcinógenos misturam-se com saliva e ficam em contato direto com a mucosa local, que por ser fina e não queratinizada está mais desprotegida (JOVANOVIC et al., 1993). Áreas intraorais menos acometidas por tumores incluem gengiva, mucosas bucal e labial, e palato duro (MASHBERG e SAMIT, 1989; SILVERMAN et al., 1998; NEVILLE e DAY, 2002; NEVILLE et al., 2004). No entanto, mudanças nesse padrão de ocorrência da doença podem ser observadas se levarmos em consideração certas características regionais. Em culturas isoladas na Índia e América do Sul, onde a prática do "fumo invertido" é bastante popular, cerca de $50 \%$ das malignidades bucais são encontradas no palato duro, local onde geralmente o câncer é pouco incidente (NEVILLE et al., 2004).

O carcinoma epidermóide resulta de um processo em que o epitélio normal sofre transformações que levam à formação de lesões displásicas, as quais podem dar origem a uma neoplasia maligna. Lesões displásicas são caracterizadas como brandas, moderadas ou severas, de acordo com critérios histomorfológicos. Displasia branda apresenta alterações limitadas a camada basal do epitélio, enquanto a moderada e a severa envolvem mudanças crescentes na morfologia celular e aumento de espessura do epitélio (PEREIRA et al., 2007). Quando as alterações celulares envolvem todas as camadas do epitélio sem, no entanto, invadir o tecido conjuntivo, a lesão é classificada como carcinoma in situ. Já o carcinoma propriamente dito é diagnosticado quando há ruptura da membrana basal e invasão de células para o estroma subjacente (SILVERMAN et al., 1998).

Histopatologicamente, o carcinoma invasivo caracteriza-se pela extensão irregular de ilhas ou cordões epiteliais através da membrana basal para o tecido conjuntivo subepitelial. Células neoplásicas podem ser observadas isoladamente ou 
formando ninhos de células que crescem dentro do tecido conjuntivo, sem ligação com o epitélio de superfície. Essas células apresentam citoplasma eosinofílico abundante e núcleos grandes e hipercromáticos. Graus variados de pleomorfismo celular e nuclear são observados, assim como acúmulos de ceratina no epitélio lesional. Células invasoras podem estender-se para o tecido adiposo subjacente, músculo ou osso. Observa-se intensa resposta inflamatória ao epitélio invasor, assim como áreas focais de necrose (NEVILLE et al., 2004; PEREIRA et al., 2007).

O grau de diferenciação celular é usado para a classificação histológica do carcinoma epidermóide. Segundo este critério, os tumores que apresentam células bem diferenciadas são considerados de grau I, os moderadamente diferenciado de grau II e os pouco diferenciados de grau III (PEREIRA et al., 2007). O grau histopatológico está relacionado ao comportamento do tumor. Lesões bem diferenciadas, com células bastante semelhantes ao epitélio normal, tendem a crescer lentamente e serem menos agressivas. Por outro lado, um tumor com alto grau de pleomorfismo celular e nuclear e pouca formação de ceratina tende a ser mais invasivo, e possui células tão imaturas que se torna difícil identificar o tecido de origem (NEVILLE et al., 2004).

Difusão local ou regional do carcinoma epidermóide oral é comum, e pode afetar a escolha da terapia e o prognóstico. Metástases para linfonodos cervicais são bastante freqüentes, e metástases à distância, quando ocorrem, costumam atingir os pulmões (EPSTEIN, 2003). Cerca de 30\% dos carcinomas orais apresentam metástases cervicais palpáveis ou ocultas no período da avaliação inicial. A metástase para linfonodos é universalmente aceita como o fator mais importante na sobrevivência de pacientes com carcinoma epidermóide oral (NEVILLE e DAY, 2002; ZIOBER et al., 2006).

Opções de tratamento para essa neoplasia maligna variam de acordo com o tamanho e localização do tumor primário, presença de metástases em linfonodos e à distância, envolvimento ósseo, tolerância ao tratamento e cooperação do paciente (NEVILLE e DAY, 2002; EPSTEIN, 2003). Cirurgia e/ou radioterapia ainda são os métodos mais utilizados para o tratamento de tumores no lábio e cavidade oral. $A$ combinação de quimioterapia, especialmente com radioterapia, pode promover melhor prognóstico (CALAIS et al., 1999).

Mesmo com grandes avanços nos métodos de diagnóstico e tratamento, a taxa de sobrevida de pacientes com carcinoma epidermóide oral em cinco anos é de 
cerca de 50\%. Isto pode estar relacionado com o fato de que a maioria dos casos só são diagnosticados quando a doença já está em estágio avançado (NEVILLE e DAY, 2002; EPSTEIN, 2003).

Apesar da forte correlação entre o carcinoma epidermóide e determinados fatores etiológicos, os mecanismos biológicos relacionados à iniciação e progressão desse tumor ainda não foram totalmente esclarecidos (MEHROTRA e YADAV, 2006). Algumas evidências sugerem que alterações observadas no carcinoma epidermóide estão relacionadas a certos processos genéticos que levam a mudanças na morfologia e comportamento celulares. Esses processos incluem ativação de proto-oncogenes e inativação de genes supressores de tumor. Os protooncogenes aumentam a proliferação celular, e podem codificar a produção de fatores de crescimento e seus receptores, fatores de transcrição, entre outros. Já os genes supressores de tumor regulam negativamente crescimento e diferenciação celulares, e sua inativação pode tornar células malignas resistentes a apoptose (HARDISSON, 2003).

Além dos proto-oncogenes e genes supressores de tumor, fatores de crescimento, moléculas de adesão celular, atividade imunológica e regulação homeostática de células normais circundantes também participam do desenvolvimento e progressão do carcinoma epidermóide (SCULLY et al., 2000). Por tal motivo, é cada vez mais aceita a idéia de que o microambiente relacionado a esta neoplasia envolve não só o componente maligno epitelial, mas também o estroma circundante. Desse modo, o crescimento e a progressão para carcinoma invasivo envolvem interações das células tumorais com células de outros tecidos e com a matriz extracelular (MEHROTRA e YADAV, 2006).

Para uma melhor compreensão da relação entre o carcinoma epidermóide e a matriz extracelular, faremos uma breve descrição de sua estrutura, componentes e funções.

\subsection{Matriz Extracelular e Membrana Basal}

O estroma é composto por vários elementos que, em conjunto, contribuem para sua homeostase. Essa estrutura é formada por componentes celulares, que incluem fibroblastos e miofibroblastos, dispostos em uma rede tridimensional 
complexa e organizada de macromoléculas de suporte conhecida como matriz extracelular (MEC) (MINER e YURCHENCO, 2004; MARASTONI et al., 2008).

Estruturalmente, a MEC contém polímeros fibrosos bem organizados, representados por várias isoformas de colágeno e por elastina, embebidos em mistura amorfa de proteoglicanas e glicosaminoglicanas altamente hidratada, chamada de substância fundamental. Glicoproteínas adesivas, como lamininas, fibronectinas e nidogênio (entactinas) também são encontradas (COLOGNATO e YURCHENCO, 2000; MAO e SCHWARZBAUER, 2005; TANZER, 2006; LI et al., 2007). Proporção entre componentes fibrosos e não fibrosos, diâmetro das fibras e organização de componentes não fibrosos ditam as propriedades físicas da matriz extracelular de um tecido específico. Proteínas da MEC são grandes e multifuncionais, contendo domínios que podem conferir várias funções a uma mesma macromolécula (HOHENESTER e ENGEL, 2002).

A matriz extracelular não é meramente um suporte estrutural para elementos celulares do estroma, e pode influenciar o comportamento celular afetando crescimento, diferenciação, motilidade e viabilidade (TANZER, 2006). As moléculas da MEC podem funcionar como reservatório para várias substâncias secretadas pelas células, que incluem fatores de crescimento, citocinas, metaloproteinases da matriz (MMPs) e enzimas de processamento. Disponibilidade dessas substâncias para as células pode ser regulada através de rearranjos da matriz, como os que ocorrem, por exemplo, durante os processos de cicatrização e de invasão de tumores malignos (MARASTONI et al., 2008). Além do mais, existem vias de comunicação bem desenvolvidas entre as superfícies celulares e a MEC, o que permite às células perceber o ambiente no qual estão inseridas (TANZER, 2006). Nesse processo, as células dependem principalmente de receptores transmembrana do tipo integrinas (MOULD e HUMPHRIES, 2004).

A matriz extracelular pode ser dividida em matriz intersticial e membrana basal. Ambas possuem uma estrutura básica composta por colágeno, sendo que a matriz intersticial é formada por colágenos tipicamente fibrilares como o tipo I, e a membrana basal por colágeno tipo IV. Glicoproteínas adesivas, como a laminina, e proteoglicanas, aderem às moléculas de colágeno e interagem com células localizadas na matriz ou adjacentes a ela (BOSMAN et al., 1992; KADLER et al., 1996). Esses componentes da MEC podem ser produzidos tanto por células do 
parênquima quanto células do estroma de um determinado tecido (TANZER, 2006; ZIOBER et al., 2006).

Virtualmente todos os órgãos e tecidos no adulto possuem uma arquitetura organizada onde células estão aderidas à membrana basal, uma camada fina e flexível de matriz extracelular altamente especializada (COLOGNATO e YURCHENCO, 2000; MINER e YURCHENCO, 2004; YURCHENCO et al., 2004; YURCHENCO e WADSWORTH, 2004; TANZER, 2006). Além de situar-se na interface entre células epiteliais e tecido conjuntivo, a membrana basal também pode ser observada recobrindo células do mesotélio, musculares, células de Schwan e adipócitos (BOSMAN e STAMENKOVIC, 2003). Essa membrana apresenta funções mecânicas de suporte, ancoragem celular e compartimentalização de tecidos, bem como determina a polaridade celular. Nos glomérulos renais e alvéolos pulmonares, atua como um filtro altamente seletivo para sais e pequenas moléculas. Participa ainda de processos de adesão, migração, crescimento e diferenciação celulares, sendo essencial para a formação e manutenção de tecidos tanto nos estágios iniciais de desenvolvimento quanto na fase adulta (COLOGNATO e YURCHENCO, 2000; SUZUKI et al., 2005)

A membrana basal é constituída predominantemente por: 1) colágeno tipo IV, um polímero não fibroso; 2) laminina, glicoproteína adesiva; 3) fibronectina; 4) nidogênio (entactina) e 5) perlecan, uma proteoglicana. Pequenas quantidades de outras proteoglicanas e glicoproteínas também podem ser encontradas (AUMAILLEY, 1995; COLOGNATO e YURCHENCO, 2000; SASAKI et al., 2004; MAO e SCHWARZBAUER, 2005). Estudos de reconstrução mostraram que, durante o processo de organização da membrana basal, o colágeno tipo IV sofre polimerização e forma um arcabouço que é reconhecido pela laminina, nidogênio e perlecan. Outras moléculas posteriormente conectam-se a esta estrutura, criando uma rede interligada que se torna resistente e insolúvel (TANZER, 2006). Em relação à ultraestrutura, não existem diferenças de arquitetura significantes entre membranas basais de vários órgãos e tecidos No entanto, sua composição pode apresentar variações, já que diferentes isoformas de colágeno IV e de laminina são sintetizadas dependendo do tecido analisado (AUMAILLEY, 1995; COLOGNATO e YURCHENCO, 2000; BOSMAN e STAMENKOVIC, 2003; TANZER, 2006).

A membrana basal serve como barreira para grandes solutos e é impenetrável para a maioria das células no tecido adulto, exceto durante processos 
inflamatórios (TANZER, 2006). Por isso, ela representa o primeiro obstáculo a ser atravessado por células neoplásicas durante o processo de invasão. No entanto, as células tumorais desenvolvem mecanismos que as permitem ultrapassar este obstáculo e migrar para o estroma circundante (BOSMAN et al., 1992; TANZER, 2006)

Para que possam disseminar-se e invadir outras estruturas, células tumorais sofrem mudanças que afetam sua morfologia e comportamento, bem como sua relação com a matriz extracelular e membrana basal (BOSMAN et al., 1992; EPSTEIN, 2003; TANZER, 2006). Essas células ainda são capazes de modificar a composição da matriz, alterando o nível de expressão de diferentes proteínas, ou promovendo degradação de componentes por ação de enzimas proteolíticas (STERNLICHT e WERB, 2001; SCHENK e QUARANTA, 2003; MOTT e WERB, 2004). Na membrana basal, especificamente, a ação destas enzimas pode gerar descontinuidades nessa estrutura, facilitando o processo de invasão (EPSTEIN, 2003; ZIOBER et al., 2006; ALEXANDROVA, 2008). Praticamente todas as modificações da MEC, mesmo que restritas a somente algumas proteínas, resultam em alterações complexas de vias regulatórias envolvendo adesão e proliferação celulares, modificações de citoesqueleto, e relação célula-matriz (ALEXANDROVA, 2008).

As células do carcinoma epidermóide interagem fortemente com a matriz extracelular, e dependem de mecanismos de adesão com essa estrutura para sua sobrevivência. Prova disso é que linhagens celulares derivadas dessa neoplasia não conseguem crescer em culturas semi-sólidas ou suspensão (RHEINWALD e BECKETT, 1980; KANTAK e KRAMER, 1998). Assim, os constituintes da matriz e seus receptores, as integrinas, devem desempenhar importantes papéis no mecanismo de progressão de carcinoma epidermóide e geração de metástase. Estudos demonstraram que mudanças na expressão de moléculas da MEC podem contribuir para crescimento hiperplásico e desenvolvimento tumoral (GINSBERG et al., 1990; CHERESH, 1992). As moléculas da matriz implicadas no desenvolvimento do carcinoma epidermóide incluem colágeno, fibronectina, tenascina e laminina (ZIOBER et al., 2001).

Em nosso laboratório, estudamos o papel da laminina no comportamento biológico de tumores (JAEGER et al., 1997; DE OLIVEIRA et al., 2001; FRANCA et al., 2001; FREITAS e JAEGER, 2002; CAPUANO e JAEGER, 2004; FREITAS et al., 
2004; FREITAS et al., 2007; MORAIS FREITAS et al., 2007; GAMA-DE-SOUZA et al., 2008). Por tal motivo, abordaremos a seguir alguns aspectos relevantes sobre a estrutura e funções dessa molécula.

\subsection{Laminina}

A laminina é a glicoproteína adesiva mais abundante na membrana basal, e exerce tanto atividades estruturais quanto biológicas (MARTIN e TIMPL, 1987; SASAKI et al., 2004). Essa molécula foi identificada em 1979 por Timpl e colaboradores, depois de ser isolada e purificada a partir de uma neoplasia de camundongo dotada de grande quantidade de membrana basal, o tumor EngelbrethHolm-Swarm (EHS) (TIMPL et al., 1979).

A laminina é uma proteína heterotrimérica composta por três cadeias $(\alpha, \beta$ e $\gamma)$, que se organizam formando uma estrutura cruciforme. Essa disposição dá origem a três braços curtos, e a um braço longo formado pelo entrelaçamento de porções de cada uma das três cadeias (MARTIN e TIMPL, 1987; MINER e YURCHENCO, 2004; AUMAILLEY et al., 2005). Através de fotomicrografias eletrônicas, observou-se que a laminina possui segmentos semelhantes a espetos, assim como domínios globulares (MARTIN e TIMPL, 1987; MINER e YURCHENCO, 2004).

A laminina apresenta isoformas resultantes da combinação de diferentes cadeias $\alpha, \beta$ e $\gamma$. Até o momento, já foram identificados cinco genes distintos para a cadeia $\alpha$, quatro para a $\beta$ e três para a cadeia $\gamma$, sendo que as cadeias $\alpha 2$, $\alpha 3$ e $\gamma 3$ podem ser também codificadas por splicing alternativo (COLOGNATO e YURCHENCO, 2000; BOSMAN e STAMENKOVIC, 2003; MINER e YURCHENCO, 2004). A união das diferentes cadeias $\alpha, \beta$ e $\gamma$ resultaria em 45 possíveis combinações heterotriméricas, sem considerar variantes de splicing. Entretanto, o número real de combinações é bem inferior, devido a restrições de união entre algumas cadeias (COLOGNATO e YURCHENCO, 2000). Atualmente, a família das lamininas é constituída por 16 isoformas, mas provavelmente existem outras que ainda não foram isoladas (MALINDA e KLEINMAN, 1996; PONCE et al., 2001; MINER e YURCHENCO, 2004). 
As isoformas de laminina são sintetizadas por praticamente todas as células epiteliais, além de células musculares lisas, de tecido ósseo, de músculo cardíaco, nervosas, endoteliais e de medula óssea. Após a síntese, esta molécula se deposita principalmente, mas não exclusivamente, na membrana basal (BOSMAN e STAMENKOVIC, 2003).

Recentemente, Aumailley e colaboradores (2005) propuseram uma nova classificação para as diferentes isoformas de laminina, que recebiam nomes de acordo com a ordem em que foram descobertas (laminina-1, laminina-2 e assim sucessivamente). Com exceção da laminina-1, era difícil relacionar uma determinada isoforma com as cadeias $\alpha, \beta$ e $\gamma$ pelas quais era formada. Foi então proposto que as isoformas da laminina fossem classificadas com uma numeração composta que representasse essas cadeias. Assim, a laminina-1, por exemplo, passaria então a ser chamada de laminina-111, já que possui cadeias $\alpha 1 \beta 1 \gamma 1$. Laminina-5, por sua vez, seria denominada laminina-332, por ser composta pelas cadeias $\alpha 3 \beta 3 \gamma 2$.

A tabela a seguir mostra as isoformas da laminina, suas cadeias e as integrinas com as quais se ligam, assim como suas classificações (BURGESON et al., 1994; AUMAILLEY et al., 2005). 
Tabela 2.1- Isoformas da laminina, suas respectivas cadeias e integrinas ligantes (BURGESON et al., 1994; KUTLESA et al., 2002; AUMAILLEY et al., 2005).

\begin{tabular}{l|l|l|l}
\hline $\begin{array}{c}\text { Classificação } \\
\text { antiga }\end{array}$ & \multicolumn{1}{c|}{$\begin{array}{c}\text { Classificação } \\
\text { Nova }\end{array}$} & \multicolumn{1}{|c}{ Cadeias } & \multicolumn{1}{c}{ Receptores (integrinas) } \\
\hline \hline Laminina-1 & 111 & $\alpha 1 \beta 1 \gamma 1$ & $\alpha 1 \beta 1, \alpha 2 \beta 1, \alpha 6 \beta 1, \alpha 6 \beta 4, \alpha 7 \beta 1$ \\
\hline Laminina-2 & 211 & $\alpha 2 \beta 1 \gamma 1$ & $\alpha 1 \beta 1, \alpha 2 \beta 1, \alpha 3 \beta 1, \alpha 6 \beta 1, \alpha 6 \beta 4, \alpha 7 \beta 1$ \\
\hline Laminina-3 & 121 & $\alpha 1 \beta 2 \gamma 1$ & ND \\
\hline Laminina-4 & 221 & $\alpha 2 \beta 2 \gamma 1$ & Similar à laminina-2 \\
\hline Laminina-5 & 332 & $\alpha 3 \beta 3 \gamma 2$ & $\alpha 3 \beta 1, \alpha 6 \beta 4, \alpha 6 \beta 1$ \\
\hline Laminina-6 & 311 & $\alpha 3 \beta 1 \gamma 1$ & ND \\
\hline Laminina-7 & 321 & $\alpha 3 \beta 2 \gamma 1$ & ND \\
\hline Laminina-8 & 411 & $\alpha 4 \beta 1 \gamma 1$ & $\alpha 6 \beta 1$ \\
\hline Laminina-9 & 421 & $\alpha 4 \beta 2 \gamma 1$ & ND \\
\hline Laminina-10 & 511 & $\alpha 5 \beta 1 \gamma 1$ & $\alpha 3 \beta 1, \alpha 6 \beta 1$ \\
\hline Laminina-11 & 521 & $\alpha 5 \beta 2 \gamma 1$ & $\alpha 3 \beta 1, \alpha 6 \beta 1$ \\
\hline Laminina-12 & 213 & $\alpha 2 \beta 1 \gamma 3$ & ND \\
\hline Laminina-13 & 323 & $\alpha 3 \beta 2 \gamma 3$ & ND \\
\hline Laminina-14 & 423 & $\alpha 4 \beta 2 \gamma 3$ & ND \\
\hline & 523 & & \\
\hline & & & \\
\hline
\end{tabular}

ND Não determinado

A laminina contribui fortemente para a organização supramolecular final da membrana basal, e neste contexto interage com ela mesma e com colágeno IV, nidogênio e proteoglicanas (MARTIN e TIMPL, 1987; MALINDA e KLEINMAN, 1996; COLOGNATO e YURCHENCO, 2000; BOSMAN e STAMENKOVIC, 2003; MINER e YURCHENCO, 2004). Além disso, parece estar relacionada com início da formação da matriz da membrana basal, já que é a primeira molécula a ser sintetizada durante 
o desenvolvimento embrionário (MALINDA e KLEINMAN, 1996; COLOGNATO e YURCHENCO, 2000). A importância da laminina é ainda reforçada pelo fato de sua ausência impedir a formação da membrana basal (YURCHENCO et al., 2004; YURCHENCO e WADSWORTH, 2004).

Além de funções estruturais, a laminina possui diversas atividades biológicas, que incluem promoção de adesão celular, espraiamento, migração, proliferação, crescimento de neuritos, metástase de tumores e secreção de protease (MARTIN e TIMPL, 1987; MALINDA e KLEINMAN, 1996; PONCE et al., 2001; BOSMAN e STAMENKOVIC, 2003). Algumas dessas atividades já foram correlacionadas a importantes eventos da progressão de neoplasias malignas, através de estudos in vitro e in vivo.

Adesão de células epiteliais malignas à laminina foi a primeira atividade biológica demonstrada para essa proteína na progressão tumoral (MALINDA e KLEINMAN, 1996). Laminina também mostrou atividade quimiotática quando em solução, o que pode explicar sua habilidade em estimular movimentos celulares necessários aos processos de invasão e metástase (MARTIN e TIMPL, 1987; MALINDA e KLEINMAN, 1996). Essa molécula ainda é capaz de induzir fenótipo maligno. Pesquisas demonstraram que células cultivadas sobre laminina formam mais tumores in vivo do que células não aderentes ou células aderentes à fibronectina (TERRANOVA et al., 1984). Ainda, células tumorais co-injetadas com laminina em ratos atímicos promoveram aumento da formação de colônias metastáticas no pulmão (IWAMOTO et al., 1987).

A laminina, assim como outras moléculas da matriz extracelular, é capaz de regular atividades celulares e pode fornecer instruções para as células. Essas instruções não são estáticas, e aparecem de acordo com a necessidade da célula (SCHENK e QUARANTA, 2003). Dissecção bioquímica da laminina relatou que algumas de suas funções são específicas a porções dessa grande glicoproteína, demonstrando que diferentes partes da laminina exercem efeitos diferentes nas células (FAISAL KHAN et al., 2002). Estudos evidenciaram que pequenas sequências de aminoácidos derivadas da laminina são capazes de estimular funções biológicas. Essas sequências são conhecidas como peptídeos bioativos e algumas das funções que exercem não são as mesmas da proteína íntegra (SCHENK e QUARANTA, 2003; HANDSLEY e EDWARDS, 2005). 
Por tal motivo, os efeitos da laminina não podem ser relacionados apenas a sua molécula como um todo já que possui, escondida em sua estrutura, diversos sítios ativos. Esses sítios não estão expostos na superfície da molécula quando na sua forma intacta, sendo por isso denominados matricriptinas ou sítios matricrípticos. As matricriptinas podem ser encontradas em diversas proteínas da matriz extracelular (SCHENK e QUARANTA, 2003).

Os mecanismos que regulam a exposição de sítios matricrípticos representam uma etapa relevante no controle dos vários eventos biológicos promovidos pela MEC. Pelo menos cinco mecanismos vinculados à geração desses sítios já foram descritos, e todos envolvem modificação estrutural ou conformacional de moléculas da matriz: 1) degradação enzimática por ação proteolítica; 2) ligação heterotípica (adsorção) a outras moléculas, levando a mudança conformacional; 3) multimerização (organização de moléculas em arranjo), (4) forças mecânicas mediadas por células, e 5) denaturação (DAVIS et al., 2000; SCHENK e QUARANTA, 2003).

A hipótese mais aceita para explicar a existência de sítios matricrípticos é a de que provavelmente eles fazem parte de uma estratégia evolutiva para controlar diferentes atividades celulares. Dessa forma, determinadas instruções podem permanecer escondidas na molécula intacta até serem requeridas, não havendo necessidade de inibidores ou bloqueio de atividade que não foi requisitada em determinado momento (SCHENK e QUARANTA, 2003).

\subsubsection{Laminina-111 e peptídeo derivado AG73}

Como o peptídeo que estudamos nesse trabalho é derivado da cadeia $\alpha 1$ da laminina-111, faremos uma breve revisão sobre esta molécula.

Dentre todas as isoformas da laminina, a laminina-111 (antiga laminina-1, 900 $\mathrm{kDa})$, formada pelas cadeias $\alpha 1$ (400kDa), $\beta 1$ (200kDa) e $\gamma 1(200 \mathrm{kDa})$ é a mais estudada e foi a primeira a ser identificada, estruturalmente analisada e sequenciada (TIMPL e BROWN, 1994; AUMAILLEY e SMYTH, 1998; EKBLOM et al., 1998; COLOGNATO e YURCHENCO, 2000).

A laminina-111 é considerada a mais importante nos estágios iniciais do desenvolvimento (TIMPL e BROWN, 1994; SASAKI et al., 2004). Experimentos 
mostraram que camundongos que não expressavam laminina-111 morriam logo após implantação do embrião, enquanto que na ausência de moléculas como perlecan, colágeno IV ou nidogênio, esta etapa transcorria normalmente (SASAKI et al., 2004).

O modelo estrutural proposto para a laminina-111 foi baseado na correlação entre análise química da proteína, observações em microscopia eletrônica e estudo de fragmentos proteolíticos purificados. Nesse modelo, as cadeias $\alpha 1, \beta 1$ e $\gamma 1$ dispõem-se como uma bobina enrolada sobre si mesma. A cadeia $\alpha 1$ possui três domínios globulares em sua porção amino-terminal, separados por repetições do tipo EGF (fator de crescimento epidermal). Na porção carbóxi-terminal existe um domínio tipo bobina e um grande domínio globular contendo 5 glóbulos. As cadeias $\beta 1$ e $\gamma 1$ são menores em relação a $\alpha$, contendo apenas dois domínios globulares e duas repetições tipo EGF na porção amino-terminal. Pontes dissulfeto unem as cadeias próximas ao domínio carbóxi-terminal, enquanto a porção amino-terminal permaneça livre (MINER e YURCHENCO, 2004; AUMAILLEY et al., 2005). As três cadeias que formam a laminina-111 apresentam três braços curtos, sendo que um possui $48 \mathrm{~nm}$ de comprimento e dois possuem $34 \mathrm{~nm}$. O braço longo tem $77 \mathrm{~nm}$ (AUMAILLEY e SMYTH, 1998).

A cadeia $\alpha 1$ é a mais conhecida e estudada cadeia da laminina-111. É encontrada no blastocisto e em uma variedade de locais durante a embriogênese, mas está praticamente ausente nos tecidos adultos (EKBLOM et al., 1998; COLOGNATO e YURCHENCO, 2000; MINER e YURCHENCO, 2004). Virtanen e colaboradores (2000) analisaram a distribuição da cadeia $\alpha 1$ em tecidos humanos adultos e embrionários, e observaram sua expressão nas membranas basais de rins e testículos, tanto no período de embriogênese quanto no adulto. Estes autores relatam ainda que a cadeia $\alpha 1$ foi encontrada nas membranas basais da tireóide, de glândulas salivar e mamária, do endométrio e de folículos capilares em desenvolvimento, mas não na membrana basal da epiderme adulta e trato digestório (VIRTANEN et al., 2000).

Além de seu papel no desenvolvimento, a laminina-111 também é uma molécula adesiva para a maioria dos tipos celulares, e ainda promove espraiamento, proliferação, crescimento de neuritos, metástase tumoral, angiogênese, secreção de protease e colagenase IV (MARTIN e TIMPL, 1987; KANEMOTO et al., 1990; 
POWELL e KLEINMAN, 1997; WEEKS et al., 1999; NOMIZU et al., 2000; KURATOMI et al., 2002; EKBLOM et al., 2003; PONCE et al., 2003; PONCE e KLEINMAN, 2003).

Células derivadas de carcinomas parecem ser capazes de sintetizar, depositar e utilizar diferentes isoformas de laminina, como a 111 (PATARROYO et al., 2002; ZIOBER et al., 2006). Superexpressão da cadeia $\alpha 1$ da laminina já foi observada em células de tumor de colo intestinal (DE ARCANGELIS et al., 2001). Estudos de Giannelli e colaboradores (2001) demonstraram que carcinoma epidermóide apresentava imunomarcação na região da membrana basal para as laminina-111 e -332, e que essa marcação era descontínua e interrompida em carcinomas invasivos. Além do mais, Zhang e colaboradores (1996) relatam que células de carcinoma epidermóide oral ligam-se fortemente e migram rapidamente sobre substratos de laminina-111, mas não sobre colágeno tipo I e fibronectina.

As várias atividades biológicas estimuladas pela laminina, tanto em células normais quanto neoplásicas, despertaram o interesse em estudar os diferentes sítios ativos da molécula. Para realizar esses estudos, foram utilizados clones de cadeias de laminina, sequências de peptídeos correspondentes a vários domínios estruturais (fragmentos proteolíticos e peptídeos sintéticos) e anticorpos.

Para pesquisar sequências biologicamente ativas na molécula de laminina111 , foram realizadas varreduras sistemáticas de sequências, com posterior síntese de 560 peptídeos das três cadeias da laminina-111 ( $\alpha 1, \beta 1$ e $\gamma 1)$, sendo 208 peptídeos da cadeia $\alpha 1,187$ da cadeia $\beta 1$ e 165 da cadeia $\gamma 1$. Depois de sintetizados, os peptídeos foram testados quanto à sua capacidade de adesão. Dentre os 560 peptídeos, apenas 51 foram identificados como sequências adesivas, sendo 25 da cadeia $\alpha 1,14$ da cadeia $\beta 1$ e 12 da cadeia $\gamma 1$ (NOMIZU et al., 1997; NOMIZU et al., 1998; NOMIZU et al., 2000; NOMIZU et al., 2001).

Dentre os peptídeos derivados da laminina-111, SIKVAV é o mais conhecido e estudado. Ele está localizado no final do braço longo da cadeia $\alpha 1$, logo acima do domínio globular (TASHIRO et al., 1989). Esse peptídeo estimula atividades biológicas como adesão, migração, crescimento de neuritos e indução de metástase experimental (TASHIRO et al., 1989; KANEMOTO et al., 1990; GRANT et al., 1992; NOMIZU et al., 1992). 
SIKVAV induz formação de espaços pseudocísticos em células derivadas de carcinoma adenóide cístico humano (CAC2) crescidas em preparados tridimensionais, fato que pode estar relacionado com secreção de MMPs (FREITAS et al., 2004). Em estudo mais recente, verificou-se que esse mesmo peptídeo estimula, de maneira dose-dependente, a secreção de MMP2 e MMP9 pelas células CAC2. A regulação dessa atividade parece envolver os receptores do tipo integrinas $\alpha 6, \alpha 3$ e $\beta 1$ e via de ERK 1/2 (FREITAS et al., 2007).

$\mathrm{Na}$ cadeia $\beta 1$, a sequência YIGSR é capaz de promover adesão celular e migração, bem como inibir angiogênese e metástases tumorais (GRAF et al., 1987; IWAMOTO et al., 1987; MORAIS FREITAS et al., 2007). As sequências PDSGR e F9 (RYVVLPR), localizadas na mesma cadeia, também promovem adesão celular (CHARONIS et al., 1988; SKUBITZ et al., 1990).

O peptídeo C16 (KAFDITYVRLKF), presente no primeiro domínio globular da cadeia $\gamma 1$, foi identificado como sequência ativa e mostrou ter forte atividade adesiva (NOMIZU et al., 1997). Foram ainda descritas como atividades desse peptídeo estimulação de crescimento de neuritos, diminuição na formação e diferenciação de ácinos, angiogênese e metástase pulmonar de células de melanoma (NOMIZU et al., 1997; PONCE et al., 2001; KURATOMI et al., 2002; PONCE e KLEINMAN, 2003). Dados de nosso laboratório também sugerem que C16 estimula migração, invasão e secreção de protease em células de carcinoma adenóide cístico através de integrinas $\alpha 5 \beta 1$ e $\alpha v \beta 3$ (GAMA-DE-SOUZA, 2008).

Um outro estudo avaliou especificamente o domínio globular da cadeia $\alpha 1$. Foram sequenciados e sintetizados 113 peptídeos, dos quais 19 foram analisados quanto à capacidade de promover adesão e inibir espraiamento celular à laminina111. Ao final, cinco peptídeos ativos foram identificados e em seguida testados em atividades biológicas adicionais (NOMIZU et al., 1995). Entre os peptídeos analisados AG73 (RKRLQVQLSIRT), localizado no quarto domínio globular (LG4), mostrou possuir a mais forte atividade adesiva, bem como efeito inibitório dosedependente sobre o espraiamento celular à laminina Este estudo demonstrou ainda que AG73 provavelmente interage com receptores de superfície celular utilizando a sequência ativa de aminoácidos LQVQLSIRT (NOMIZU et al., 1995).

Os efeitos de AG73 já foram testados em várias células e sistemas, tanto in vitro quanto in vivo (HOFFMAN et al., 1998; HOFFMAN et al., 2001; ENGBRING et 
al., 2002; IKEMOTO et al., 2006). Esse peptídeo promove adesão de vários tipos celulares (NOMIZU et al., 1995; NOMIZU et al., 1998), e está envolvido na diferenciação acinar de glândulas salivares através de interação com o receptor sindecana-1 (HOFFMAN et al., 1998; HOSOKAWA et al., 1999). Ainda em relação a glândulas salivares, AG73 inibe morfogênese por brotamento dessas estruturas (KADOYA et al., 1998; KADOYA e YAMASHINA, 2005). Ele ainda é capaz de estimular crescimento de neuritos (RICHARD et al., 1996; RIALAS et al., 2000), e secreção de MMPs em células neuronais PC12 (WEEKS et al., 1998).

AG73 também tem uma grande relevância em biologia tumoral (SONG et al., 1997; KIM et al., 1998; ENGBRING et al., 2002; SUZUKI et al., 2003; SUZUKI et al., 2005; MOCHIZUKI et al., 2007; ENGBRING et al., 2008). Quando co-injetado com células de melanoma B16F10, esse peptídeo promoveu maior número de metástases em pulmões, no fígado e em tecido ósseo (SONG et al., 1997; KIM et al., 1998; ENGBRING et al., 2008).

Laminina-111 e AG73 co-injetados com células de tumor ovariano induziram aumento na taxa de crescimento tumoral e metástase. O peptídeo aumentou ainda a expressão de Mdm2 e Bcl2, genes relacionados à inibição de apoptose, nessas células (YOSHIDA et al., 2001). AG73 também promoveu metástases de células de carcinoma de mama MDA-231 em tecido ósseo (ENGBRING et al., 2008).

Adicionalmente, esse peptídeo também está relacionado a angiogênese em diferentes sistemas, como anéis aórticos, formação de tubo endotelial e membrana corioalantóica, e por isso pode ter aplicação terapêutica em injúrias isquêmicas (MOCHIZUKI et al., 2007). O uso de AG73 também já foi indicado em regeneração e engenharia tecidual, devido a seu potencial de promover adesão celular e formação de filopódia quando conjugado a membranas de quitosana (MOCHIZUKI et al., 2003; IKEMOTO et al., 2006; HOZUMl et al., 2009).

Nosso laboratório demonstrou que AG73 é capaz de regular a morfologia de células derivadas de neoplasias de glândula salivar (OLIVEIRA, 2004; GAMA-DESOUZA et al., 2008). Adicionalmente, esse peptídeo promoveu atividade de adesão e estimulou secreção de proteases através da interação com os receptores sindecana-1 e integrina $\beta 1$ em linhagens celulares derivadas de carcinoma adenóide cístico e mioepitelioma humanos (GAMA-DE-SOUZA et al., 2008).

Apesar da sua significância biológica, os efeitos do peptídeo AG73 ainda não foram estudados em carcinoma epidermóide. 


\subsection{Metaloproteinases da matriz}

Para que uma célula tumoral de origem epitelial invada tecidos circunjacentes e promova metástases, ela precisa primeiramente perder suas estruturas de adesão e se separar das células vizinhas. Em seguida, deverá penetrar através da membrana basal e abrir caminho ao redor do estroma que a circunda, podendo então alcançar vasos sanguíneos e chegar à circulação. Para isso, é necessária extensiva degradação de componentes da matriz extracelular, incluindo colágeno, fibronectina, laminina e proteoglicanas (MOSCATELLI et al., 1988; WOESSNER, 1991). Células neoplásicas, assim como células normais, podem realizar esses procedimentos porque são providas de uma bateria de metaloendopeptidases que digerem várias proteínas da matriz (WOESSNER, 1991).

Com base em semelhanças estruturais, um grupo de proteases com íon zinco e resíduo metionina no sítio catalítico forma a superfamília de metzincinas, que está dividida em quatro subfamílias: serralisinas, adamalisinas, astracinas e matrixinas (STAMENKOVIC, 2003).

As metaloproteinases de matriz (MMPs) formam a subfamíla das matrixinas, que contém mais de 20 endopeptidases dependentes de $\mathrm{Zn}^{2+}$ capazes de degradar diversos componentes da matriz extracelular (STAMENKOVIC, 2003; RUNDHAUG, 2005; PAGE-MCCAW et al., 2007). As MMPs são denominadas com número correspondente à cronologia de sua descoberta; todavia, uma nova nomenclatura com base na estrutura dessas proteínas já foi abordada (STAMENKOVIC, 2003).

As MMPS são sintetizadas na forma de pré pro-enzimas e, na maioria dos casos, secretadas como pro-MMPs inativas (STAMENKOVIC, 2003; RUNDHAUG, 2005). A subclasse de MMPs com estrutura mais simples é a matrilisina, formada por um peptídeo sinal, um domínio pró-peptídico e um domínio catalítico com sítio de ligação com zinco (MCCAWLEY e MATRISIAN, 2001; LYNCH e MATRISIAN, 2002; STAMENKOVIC, 2003; RUNDHAUG, 2005). O domínio pró-peptídico possui uma sequência conservada dotada de um aminoácido cisteína, o qual se liga ao domínio catalítico de zinco e é responsável pela manutenção da latência das pro-MMPs (RUNDHAUG, 2005). O domínio catalítico contém sítios de ligação para zinco e íons cálcio, necessários para sua estabilidade e atividade enzimática (NAGASE e WOESSNER, 1999; RUNDHAUG, 2005). 
As MMPs são subdivididas em matrilisinas, colagenases, gelatinases, estromelisinas e metaloproteinase de matriz tipo membrana (MT-MMPs) (MCCAWLEY e MATRISIAN, 2001; LYNCH e MATRISIAN, 2002)

As colagenases degradam colágenos tipo I, II, III (colágenos intersticiais) e outras isoformas dessa proteína (MADSEN et al., 2007). As estromelisinas possuem domínios estruturais semelhantes aos das colagenases, porém apresentam como substratos várias proteínas da MEC, como proteoglicanas, fibronectina e laminina (NAGASE e WOESSNER, 1999; RUNDHAUG, 2005). As MMPs tipo membrana (MT-MMPs) estão ligadas à superfície celular através de um domínio transmembrana e degradam gelatina, fibronectina e agrecan, além de outros substratos da matriz extracelular (LEE e MURPHY, 2004; RUNDHAUG, 2005).

As gelatinases interagem com colágeno tipo IV (presente na membrana basal), V, VII e X, além de fibronectina, elastina e laminina. Duas proteínas pertencem a essa família: gelatinase A ou MMP2 $(72 \mathrm{kD})$ e gelatinase $B$ ou MMP9 (92 kD). MMP9 é secretada por células epiteliais e também estocada em grânulos secretórios de neutrófilos e eosinófilos. Essa enzima tem uma produção mais restrita, sendo altamente induzida e controlada por fatores de crescimento, quimiocinas e outros estimuladores. Já a MMP2 é expressa por vários tipos celulares, especialmente fibroblastos, e sua secreção é constitutiva, com modestos aumentos e diminuições sob diferentes condições (NAGASE e WOESSNER, 1999; MCCAWLEY e MATRISIAN, 2001; LYNCH e MATRISIAN, 2002; LEE e MURPHY, 2004; RUNDHAUG, 2005).

Controle acurado da atividade de proteases é crucial para evitar danos teciduais indesejáveis (BJORKLUND e KOIVUNEN, 2005). Esse controle pode envolver processos de transcrição, ativação proteolítica, e inibição da atividade enzimática por inibidores naturais. A maioria das MMPs é expressa em baixos níveis ou não é expressa em tecidos adultos. No entanto, várias citocinas, fatores de crescimento e interações celulares podem induzir rápida expressão de MMPs (OVERALL e LOPEZ-OTIN, 2002; STAMENKOVIC, 2003; BJORKLUND e KOIVUNEN, 2005). Ruptura da ligação cisteína-zinco por mecanismos físicos ou químicos é o primeiro passo na ativação dessas enzimas (RUNDHAUG, 2005).

Os maiores inibidores fisiológicos das MMPs são a $\alpha 2$ macroglobulina, e a família dos inibidores teciduais de metaloproteinases, conhecidas como TIMPs. Estas proteínas ligam-se não covalentemente a MMPs ativas e inibem sua atividade 
enzimática, sendo produzidas por uma variedade de células tais como fibroblastos, queratinócitos, células endoteliais e osteoblastos. Quatro tipos de TIMPS, as TIMP1, -2,-3 e -4, já foram descobertas (WOESSNER, 2001).

As MMPs estão envolvidas em diversos processos fisiológicos como desenvolvimento, remodelação óssea, cicatrização, angiogênese e apoptose (NAGASE e WOESSNER, 1999). As funções das MMPs nesses processos são bastante variadas. Elas são capazes de promover proteólise, criando espaço para migração celular ou produzindo fragmentos que estimulam atividades biológicas. Podem ainda regular a arquitetura celular através de modificações na matriz e junções intercelulares, bem como afetar funções das células, controlando as proteínas de matriz com as quais elas interagem. As MMPs também podem ativar, desativar ou modificar moléculas de sinalização (PAGE-MCCAW et al., 2007).

Além do importante papel em eventos fisiológicos, as MMPs participam das respostas imune e inflamatória, e de vários processos patológicos tais como artrite, câncer, doença cardiovascular, úlcera gástrica e enfisema (NAGASE e WOESSNER, 1999).

Em relação ao câncer, um dos fatores mais importante para crescimento invasivo e metástases é a destruição e remodelação da arquitetura da matriz extracelular. A proteólise ajuda a formar "canais" para a migração celular através de rompimento da membrana basal e degradação da matriz, e estes eventos estão intimamente relacionado à ação de MMPs (LYNCH e MATRISIAN, 2002; BJORKLUND e KOIVUNEN, 2005; RUNDHAUG, 2005). Ensaios realizados em matrizes 3D mostraram que degradação proteolítica é um componente essencial de movimentos celulares individuais na matriz extracelular, e que MMPs tendem a acumular-se no "front" de migração da célula (WOLF et al., 2003; YAMAZAKI et al., 2005).

No entanto, as metaloproteinases da matriz possuem um papel muito mais complexo que o de simplesmente abrir caminhos na matriz. Essas enzimas também regulam o acesso a fatores de crescimento, promovem angiogênese e migração celular, e alteram o ambiente celular. Dessa forma, estabelecem um microambiente que oferece suporte para o início e manutenção de neoplasias malignas (CHAMBERS e MATRISIAN, 1997; SCHENK e QUARANTA, 2003; BJORKLUND e KOIVUNEN, 2005). 
Entre as várias MMPs envolvidas na tumorigênese, as MMP2 e a MMP9 se destacam. Expressão aumentada dessas MMPs já foi observada em neoplasias de mama, colo do útero, pulmão, pele, ovário e próstata (EGEBLAD e WERB, 2002). Esse aumento quase sempre vem acompanhado de atividades invasiva e metastática mais proeminentes, que levam a uma diminuição da sobrevida. Foi demonstrado que MMP9 libera fatores de crescimento, como VEGF e TGF- $\beta$, promovendo angiogênese e crescimento do tumor (BERGERS et al., 2000; MIRA et al., 2004; RUNDHAUG, 2005). Ainda, essas enzimas atuam liberando fragmentos protéicos, sítios crípticos e outros fatores com atividade quimiotática presentes na matriz extracelular, que por sua vez estimulam migração. MMP2 e MMP9 foram relacionadas com espraiamento celular, mudanças no citoesqueleto durante a migração, e desestabilização de adesões focais (BJORKLUND e KOIVUNEN, 2005).

Vários trabalhos já demonstraram a relação entre as MMPs 2 e 9 e carcinoma epidermóide da região de cabeça e pescoço. Em um deles, foi observada atividade gelatinolítica elevada dessas duas MMPs em carcinomas orais quando comparados com mucosa normal (OHASHI et al., 2000). Em outro trabalho, 9 de 10 casos de tumores de faringe expressaram MMP9, enquanto MMP2 foi fracamente expressa (HEISSENBERG et al., 1998). MMP9 também foi correlacionada com péssimo prognóstico e níveis elevados de substâncias angiogênicas, como VEGF, em carcinoma epidermóide de cabeça e pescoço (HEISSENBERG et al., 1998; IKEBE et al., 1999; RIEDEL et al., 2000). Contudo, ainda não se sabe se síntese elevada de MMPs é promovida por células tumorais ou por fibroblastos do estroma circundante (WERNER et al., 2002).

\subsection{Integrinas}

Embora mais de 20 receptores tenham sido descritos para laminina-111, os mais conhecidos são as integrinas (HYNES, 1987; 1992; MERCURIO, 1995; HYNES et al., 2002; WERNER et al., 2002; HYNES, 2003). Esses receptores estão envolvidos em interações célula-célula e célula-matriz tanto em processos fisiológicos quanto patológicos, e estão presentes em uma extensa variedade de células (HYNES, 1987; 1992; DE MELKER e SONNENBERG, 1999; MIRANTI e BRUGGE, 2002; WERNER et al., 2002). 
São glicoproteínas heterodiméricas formadas por duas subunidades $\alpha$ e $\beta$ ligadas de maneira não covalente, e que juntas possuem o peso molecular de 140 kDa (TAMKUN et al., 1986). Em mamíferos, já foram identificados 18 genes codificantes da subunidade $\alpha$ e oito da $\beta$, cuja combinação poderia dar origem a mais de cem heterodímeros. Contudo, até hoje só foram descritos 24 tipos de integrinas, o que ocorre devido ao fato de algumas subunidades $\alpha$ só se combinarem com um único tipo de subunidade $\beta$ (HYNES, 1987; 1992; DE MELKER e SONNENBERG, 1999). Essas proteínas dependem de cátions divalentes (como $\mathrm{Ca}^{2+}$ e $\mathrm{Mg}^{2+}$ ) para estabelecer ligações com outras moléculas (HYNES, 1992; DE MELKER e SONNENBERG, 1999; HYNES et al., 2002).

As integrinas são receptores do tipo transmembrana, e possuem um domínio extracelular, um domínio citoplasmático e um segmento transmembrana hidrofóbico. O nome integrina foi proposto justamente porque os autores consideram essa estrutura um complexo que integra a matriz extracelular e o citoesqueleto. domínio extracelular é maior que o citoplasmático, e pode se apresentar em duas conformações. A conformação "aberta" possui alta afinidade/atividade, enquanto a "fechada" apresenta baixa afinidade/atividade (HYNES, 1992; DE MELKER e SONNENBERG, 1999; HYNES et al., 2002).

Os domínios citoplasmáticos ligam-se ao citoesqueleto e interagem com vias de sinalização relacionadas a integrinas. Várias proteínas já foram descritas como ligantes da cauda citoplasmática desses receptores, sendo que a maioria interage com a subunidade $\beta$ (HYNES, 1992; HYNES et al., 2002). Trabalhos demonstraram que essa subunidade apresenta colocalização com fibronectina e componentes do citoesqueleto como actina, $\alpha$-actinina, vinculina e talina (HYNES, 1992; CALDERWOOD et al., 1999; MIRANTI e BRUGGE, 2002).

As caudas citoplasmáticas das duas subunidades desempenham papel importante na regulação do estado de ativação das integrinas, afetando estrutura e função de seus domínios extracelulares. Quando as subunidades $\alpha$ e $\beta$ se encontram associadas, mantem o receptor em seu estado inativo (HYNES et al., 2002). Mudanças conformacionais nas porções citoplasmáticas levam à ativação do domínio de ligação e posterior interação com o ligante na porção extracelular da integrina. Esse tipo de sinalização é conhecido como "de dentro para fora" (insideout signalling), e envolve mecanismos intracelulares capazes de regular a atividade 
de ligação das integrinas na superfície celular (COPPOLINO e DEDHAR, 2000; HYNES et al., 2002).

Em contrapartida, ligação de moléculas à porção extracelular das integrinas aumenta a separação das caudas das subunidades citoplasmáticas, permitindo interação com o citoesqueleto e também com moléculas sinalizadoras do citoplasma. Esse tipo de sinalização é chamado "de fora para dentro" (outside-in signalling), e é essencial para a sobrevivência celular (COPPOLINO e DEDHAR, 2000; HYNES et al., 2002).

Além da ativação de integrinas por mudança conformacional, outro modelo descrito propõe a formação de um agregado (clustering) desses receptores na superfície da membrana plasmática. Ativação conformacional e agregação de integrinas ocorrem tipicamente juntas, e é possível que um evento leve ao outro (HYNES, 2003).

As integrinas interagem com baixa afinidade a seus ligantes e de modo geral, estão presentes em grandes concentrações na superfície celular. Essas características permitem que se formem ligações simultâneas, porém fracas, a várias moléculas da $\mathrm{MEC}$, permitindo que as células explorem o ambiente sem perder sua ligação à matriz (HYNES, 1987; 1992; HYNES et al., 2002).

Entre os eventos intracelulares gerados pela ativação de integrinas, destacam-se: 1) elevação dos níveis de cálcio intracelular; 2) fosforilação de serina e tirosina de proteínas citoplasmáticas; 3) acúmulo de GTP ligado a p21; 4) ativação de sistemas de transporte de membrana; 5) alcalinização citoplasmática; 6) mudanças no metabolismo fosfolipídico e; 7) mudanças na expressão gênica (RICHARDSON e PARSONS, 1995; COPPOLINO e DEDHAR, 2000).

$\mathrm{Na}$ tentativa de compreender melhor os mecanismos moleculares envolvidos na transmissão das mensagens entre as caudas citoplasmáticas e mediadores intracelulares, vários estudos propuseram-se a buscar proteínas "associadas às integrinas", que podem interagir diretamente com esses receptores ou modular suas funções. Até o momento, vários candidatos com propriedades funcionais interessantes foram identificados, e incluem proteínas integrais de membrana e proteínas intracelulares (GIANCOTTI e TARONE, 2003).

Uma classe de moléculas relacionadas às integrinas é a família das sindecanas. Essas proteoglicanas não se ligam diretamente à molécula da integrina, mas sim a domínios separados dos ligantes desses receptores. Como as integrinas 
não possuem atividade intrínseca de proteína quinase, essa atividade é realizada através de um colaborador no intuito de controlar a sinalização. Desse modo, associação de integrinas e sindecanas pode contribuir pata estabelecer regulação mais específica de alguns eventos celulares, como adesão, migração e invasão (WOODS e COUCHMAN, 1994).

As integrinas não são simples receptores de adesão. Essas moléculas são capazes de transmitir sinais químicos e mecânicos, que resultam em rearranjo do citoesqueleto celular e ativação de vias regulatórias (SCHWARTZ, 1997). A interação célula-matriz extracelular através de integrinas é tão importante que distúrbios nesse processo podem promover apoptose em células normais (FRISCH e RUOSLAHTI, 1997). A habilidade de sobreviver sem contato com substratos é característica de células tumorais. Mas mesmo nesse caso, as células ainda dependem de sinais gerados por integrinas tanto no começo da carcinogênese quanto durante a progressão tumoral (BISSELL e RADISKY, 2001).

Integrinas exercem papel relevante mediando os efeitos da laminina no comportamento celular, incluindo adesão, migração e diferenciação. Ao se ligarem à laminina, esses receptores modulam diversas vias de sinalização intracelular. A lista de integrinas para esta glicoproteína é longa, e inclui $\alpha 1 \beta 1, \alpha 2 \beta 1, \alpha 3 \beta 1, \alpha 6 \beta 1, \alpha 7 \beta 1$, $\alpha v \beta 3$ e $\alpha 6 \beta 4$ (MERCURIO, 1995; PATARROYO et al., 2002).

Uma hipótese para a abundância de lamininas e integrinas existentes é a de que a diversidade de receptores contribui para a especificidade dos fenômenos com os quais as lamininas estão envolvidas (MERCURIO, 1995). As interações entre essas duas moléculas podem ou não ser específicas (PATARROYO et al., 2002). Um dos mais importantes receptores funcionais para a laminina-111 parece ser a integrina $\alpha 6 \beta 1$, devido a sua ampla expressão e envolvimento em vários fenômenos biológicos, tanto em condições fisiológicas quanto patológicas (MERCURIO, 1995; PATARROYO et al., 2002).

As integrinas reconhecem principalmente as cadeias $\alpha$ da laminina e a partir de então determinam adesão celular e repostas às diferentes isoformas dessa molécula. Embora algumas funções possam ser comuns a todas as isoformas, outras são únicas e específicas a uma determinada laminina, dependendo do tecido e órgão nos quais ela está mais expressa. Integrinas também reconhecem as 
cadeias $\beta$ e $\gamma$ das lamininas, porém essas interações são menos compreendidas (PATARROYO et al., 2002).

Células derivadas de carcinoma epidermóide expressam algumas integrinas que funcionam como receptores para a laminina. Comparação entre várias linhagens de carcinomas epidermóides revelou que as integrinas $\alpha 2 \beta 1$ e $\alpha 3 \beta 1$ estavam mais expressas em células metastáticas do que em não metastáticas (SHINOHARA et al., 1999). Análise imunohistoquímica de biópsias invasivas e metastáticas de carcinoma epidermóide também indicaram forte expressão desses receptores (THORUP et al., 1998; SHINOHARA et al., 1999).

Análises utilizando bloqueio com anticorpos anti-integrina mostraram que células de carcinoma epidermóide usam integrina $\alpha 6 \beta 1$ para aderir e migrar sobre a laminina-111 e que, diferentemente dessas células, queratinócitos normais expressaram níveis muito baixos da subunidade $\beta 1$ de integrina. Esse estudo ainda sugere que migração de células derivadas de carcinoma sobre laminina, mediada pela integrina $\alpha 6 \beta 1$, constitui um importante processo durante invasão e metástase (ZHANG et al., 1996).

\subsection{Sindecanas}

As sindecanas fazem parte do grupo das proteoglicanas de heparan sulfato, juntamente com as glipicanas e proteoglicanas da matriz extracelular (como perlecan e agrina). São as principais proteoglicanas transmembrana encontrada nas células, e ligam-se a uma grande variedade de moléculas através de cadeias de heparan sulfato, exercendo importantes papéis na adesão célula-matriz e célula-célula, migração, proliferação e diferenciação (CAREY et al., 1992; ALEXOPOULOU et al., 2007). Essas moléculas também participam de eventos patológicos como doenças infecciosas, renais e cardíacas (FEARS e WOODS, 2006).

As sindecanas, estruturalmente, apresentam polímeros de carboidratos longos e não ramificados, denominados glicosaminoglicanas, covalentemente aderidos a uma proteína central. Muito do que se sabe sobre a estrutura dessas moléculas é baseada na análise de sequências de aminoácidos deduzidas a partir de cDNAs. Quatro sindecanas distintas, mas também homólogas, foram identificadas a partir de cDNAs clonados de células de vertebrados (SAUNDERS et 
al., 1989; CAREY et al., 1992; CAREY, 1997). A proposta para uma nomenclatura comum designa as sindecanas numericamente, baseando-se na ordem de clonagem de seu cDNA (BERNFIELD et al., 1992).

As sindecanas apresentam um complexo padrão de expressão em determinadas células e períodos do desenvolvimento. Uma análise levou à conclusão de que praticamente todas as células expressam pelo menos um tipo de sindecana, a maioria expressa mais de uma forma, e um distinto padrão de expressão dessa molécula caracteriza tipos individuais de células e tecidos (KIM et al., 1994).

A sindecana-1 é amplamente expressa em células epiteliais, e é considerada importante reguladora de interações célula-célula e célula-matriz. Diminuição de sua expressão em células epiteliais pode resultar em perda de polaridade associada com nível reduzido de E-caderina na superfície celular, sugerindo envolvimento na transição epitélio-mesênquima durante desenvolvimento e cicatrização (COUCHMAN et al., 2001). Superexpressão de sindecana-1 ou clivagem de seu ectodomínio pode inibir proliferação induzida por FGF2 (MALI et al., 1993). Esse receptor também está relacionado ao espraiamento de células de tumores de mama (BEAUVAIS e RAPRAEGER, 2003) e células linfoblastóides (LEBAKKEN e RAPRAEGER, 1996).

Sindecana-2 é encontrada em células mesenquimais, neuronais e de músculo liso, enquanto sindecana-3 é a mais expressa no sistema nervoso. Já a sindecana-4 é encontrada em vários tecidos, mas em níveis menores que as demais sindecanas (PIERCE et al., 1992; CHERNOUSOV e CAREY, 1993; CIZMECI-SMITH et al., 1997; YONEDA e COUCHMAN, 2003).

Todas as sindecanas são proteínas transmembrana tipo I. Elas apresentam peptídeo sinal localizado em sua extremidade N-terminal, um domínio extracelular com várias sequências consenso para adesão de glicosaminoglicanas, um único domínio transmembrana hidrofóbico e um pequeno domínio C-terminal citoplasmático. Os domínios extracelulares das sindecanas possuem apenas uma limitada semelhança em suas sequências de aminoácidos. Em contraste, os domínios transmembrana e citoplasmático são altamente conservados. Os domínios citoplasmáticos são pequenos, e a sequência de aminoácidos que se liga imediatamente ao domínio transmembrana é essencialmente idêntica em todas as sindecanas, incluindo as encontradas em invertebrados (SAUNDERS et al., 1989; 
MALI et al., 1990; CAREY, 1997). Apesar dos genes que codificam as quatro sindecanas de vertebrados terem sofrido algumas modificações durante a evolução, houve forte pressão seletiva para manter a estrutura primária de seus domínios citoplasmáticos. Esse evento, associado à diversidade dos domínios extracelulares, sugerem que diferentes sindecanas evoluíram para realizar funções similares, mas não idênticas (CAREY, 1997).

Com exceção das moléculas recém-sintetizadas, a ocorrência natural de sindecanas sem glicosaminoglicanas ainda não foi descrita. A adição dessas cadeias de carboidratos é um processo pós-translacional crítico, já que determina todos os sítios de interação das sindecanas com ligantes extracelulares. Distintas formas de sindecanas são produzidas como resultado da variação de número, tipo, comprimento ou estrutura das glicosaminoglicanas adicionadas (KATO et al., 1994; SANDERSON et al., 1994).

A maioria das cadeias de glicosaminoglicanas adicionadas à proteína central de sindecanas são do tipo heparan sulfato, apesar de sindecana-1 (RAPRAEGER et al., 1985) e sindecana-4 (SHWORAK et al., 1994) também serem modificadas por cadeias de condroitin sulfato. A modalidade de glicosaminoglicana ligada à sindecana parece ter importantes consequências funcionais (CAREY, 1997). Diferentes tipos celulares mostraram sintetizar sindecanas com diferentes estruturas de glicosaminoglicanas, o que pode ser responsável por diferenças em suas atividades (SANDERSON e BERNFIELD, 1988). No entanto, a interação de ligantes extracelulares mediada por heparan sulfato parece ser o centro da atividade funcional das sindecanas (CAREY, 1997).

Apesar de sua importância em vários processos celulares, as sindecanas, assim como outras proteoglicanas, não são receptores primários de moléculas da matriz extracelular, fatores de crescimento ou quimiocinas. Na verdade, essas moléculas cooperam com outros receptores, e sua função parece estar relacionada à ativação ligante-dependente de receptores primários na superfície celular (CAREY, 1997; BASS et al., 2009).

As sindecanas conseguem realizar essa cooperação através de interação, via cadeias de glicosaminoglicanas, com ligantes extracelulares de receptores primários. Esse processo pode ter importantes consequências: 1) aumento da concentração efetiva de ligantes na superfície celular e da ativação de receptores de sinalização, evento importante em baixas concentrações de determinada substância; 2) aumento 
das possibilidades de interações de ligantes extracelulares na superfície da célula; 3) distribuição restrita de ligantes a domínios específicos da membrana, de acordo com distribuição espacial das próprias sindecanas; 4) dimerização ou oligomerização de ligantes, aumentando ativação de receptores primários de sinalização; 5) promoção de sítios de ligação secundários adesivos que complementam ligações mediadas por receptores primários 6) estabilização da adesão celular mediada por associações de sindecanas com citoesqueleto, aumentando a força de adesão de maneira geral (CAREY, 1997).

Já foi estabelecido que sindecanas podem cooperar sinergicamente com integrinas na formação de complexos de adesão, espraiamento celular e migração direcional. Além do mais, existe cooperação entre sindecanas e integrinas $\alpha 2 \beta 1$ e $\alpha 6 \beta 4$, que se ligam a lamininas. As sindecanas podem funcionar como ativadores de integrinas (BEAUVAIS et al., 2004). Desse modo, combinações individuais de pares de sindecanas e integrinas influenciam o tipo de proteína de sinalização que será recrutada, consequentemente modulando a reposta fisiológica frente a uma determinada situação (STREULI e AKHTAR, 2009).

Contudo, existem algumas evidências de que sindecanas também são capazes de transduzir sinais através da membrana, apesar de se saber pouco sobre o mecanismo através do qual as porções intra e extracelular estão integradas (BASS et al., 2007). A clivagem proteolítica do domínio extracelular de sindecanas parece ter papel fundamental em regular interações dessas moléculas com ligantes e gera sinalização intracelular. Esse processo promove acúmulo de domínios extracelulares clivados que competem com moléculas intactas de sindecanas por ligantes extracelulares, reduzindo a capacidade de sinalização de sindecanas intactas e de seus receptores associados (SANDERSON et al., 2005). Esse mecanismo pode participar da regulação da homeostase em alguns eventos biológicos como a cicatrização, protegendo o organismo contra dano tecidual ao controlar a disponibilidade de quimiocinas (SUBRAMANIAN et al., 1997; BASS et al., 2009).

Com base nessas observações, as sindecanas parecem ter dois papéis distintos: 1) funcionam como co-receptores, facilitando interações entre ligantes extracelulares e receptores; e 2) possuem capacidade de sinalização e propagam sinais intracelulares em resposta a modificações da matriz extracelular. Assim, a importância da função de sindecanas parece estar na integração desses dois processos aparentemente distintos (BASS et al., 2009). 
As sindecanas apresentam sítios de ligação para a molécula de laminina (OKAMOTO et al., 2003), e diversos trabalhos já demonstraram a correlação entre sindecanas e o peptídeo AG73. Foi demonstrado que o receptor de células de melanoma B16F10 relacionado à metástase induzida por AG73 é uma proteoglicana sulfatada, e que essa molécula é funcionalmente importante na interação célulapeptídeo (ENGBRING et al., 2002). Estudos utilizando domínio globular recombinante da cadeia $\alpha 1$ da laminina sugerem que AG73 funciona como um importante sítio de ligação para heparina/heparan sulfato e, portanto, de adesão à laminina-111 (SUZUKI et al., 2003). Moléculas de laminina com mutações na região do domínio LG4 onde está localizado AG73 não aderiram a heparina ou células linfóides que expressavam sindecanas, demonstrando que esse domínio da laminina liga-se a sindecanas através da sequência de aminoácidos correspondente ao AG73 (HOZUMI et al., 2006). Em células HSG, o peptídeo AG73 está envolvido na diferenciação acinar de glândulas salivares através de interação com sindecana-1 e integrina $\beta 1$ (HOFFMAN et al., 1998). 


\section{PROPOSIÇÃO}

Esse trabalho tem como objetivo analisar as atividades de migração, invasão e secreção de metaloproteinases da matriz induzidas pelo peptídeo AG73 em células derivadas de carcinoma epidermóide oral. Adicionalmente, buscamos por potenciais receptores envolvidos na transdução de sinais gerados pelo peptídeo. $O$ estudo envolveu as seguintes etapas:

1) Efeito do peptídeo bioativo $A G 73$ nas atividades de migração, invasão e secreção de MMPs em células de carcinoma epidermóide oral (OSCC).

2) Análise de possíveis receptores que se ligariam ao peptídeo AG73 e transduziriam sinais por ele gerado em células OSCC. Esse sinais estariam envolvido nas atividades biológicas de migração, invasão e atividade de protease. 


\section{MATERIAL E MÉTODOS}

O presente trabalho não envolveu manipulação direta nem de seres humanos e nem de animais, e foi aprovado pelo Comitê de Ética e Pesquisa (CEP-ICB), parecer $\mathrm{n}^{\circ}$ 285, de 19 de fevereiro de 2009.

\subsection{Detecção da cadeia $\alpha 1$ da laminina e MMP9 in vivo e in vitro em carcinoma epidermóide oral}

\subsubsection{Imunohistoquímica}

Cinco amostras de carcinoma epidermóide oral humano, fixadas em $4 \%$ paraformaldeído e incluídas em parafina, foram selecionadas de arquivo pertencente ao nosso Laboratório. Cortes histológicos de $3 \mu \mathrm{m}$ dessas amostras foram montados em lâminas cobertas por 3-aminopropiltrietoxi-silano (Sigma Chemical Corp., St Louis, MO, USA) e estudados por imunohistoquímica. Os cortes foram desparafinados em xilol e hidratados em concentrações decrescentes de etanol $(100 \%, 90 \%$ e $80 \%)$. Atividade da peroxidase endógena foi inibida por incubação dos cortes com $3 \% \mathrm{H}_{2} \mathrm{O}_{2}$ em metanol (1:1) por 20 minutos. Em seguida, foi realizada recuperação antigênica em câmara de pressão Pascal (Dako Cytomation, Carpinteria, CA, USA) por 30 segundos a $125^{\circ} \mathrm{C}$, utilizando tampão citrato $(10 \mu \mathrm{M}$ ácido cítrico, $0.05 \%$ Tween $20, \mathrm{pH}$ 6). Os cortes foram então bloqueados com solução de 1\% BSA (Sigma) em PBS por 1 hora. Para detecção da cadeia $\alpha 1$ da laminina, foi utilizado anticorpo produzido em coelho HK-175 (gentilmente cedido pela Dra. Hynda Kleinman, NIDCR, NIH, USA). MMP9 foi detectada utilizando anticorpo monoclonal gerado em camundongo (IM37L, Calbiochem Inc., San Diego, CA, USA). Os anticorpos primários foram diluídos 1/50 em PBS, e aplicados sobre os cortes por 1 hora em câmara úmida. Após lavagem com PBS, lâminas foram submetidas ao sistema de detecção EnVision Plus conjugado com polímero de peroxidade anti-coelho ou anti-camundongo (Dako) em câmara úmida por 20 minutos. Diaminobenzidina (Dako) foi usada como cromogênio e cortes foram contra-corados com hematoxilina de Mayer (Sigma). Substituição do anticorpo primário por soro não específico serviu como controle negativo. 


\subsubsection{Cultura da linhagem celular OSCC}

Linhagem celular derivada de carcinoma epidermóide primário humano da cavidade oral (células OSCC) foi cultivada em meio de cultura de Eagle modificado por Dulbecco (DMEM, Sigma), suplementado com 10\% de soro fetal bovino (SFB, Cultilab, Campinas, SP, Brazil), e mantida em frascos de $75 \mathrm{~cm}^{2}$ em atmosfera de $5 \% \mathrm{CO}_{2}$ a $37 \stackrel{\circ}{\circ}$. Células OSCC foram gentilmente cedidas pelo Prof. Ricardo Bentes Azevedo (Departamento de Genética e Morfologia, Instituto de Ciências Biológicas, UnB). Sua caracterização já foi descrita anteriormente (LEE et al., 2002; LEE et al., 2005).

Toda manipulação das células foi realizada em capela de fluxo laminar. Seu crescimento foi monitorado diariamente em microscópio invertido de contraste de fase. Meio de cultura foi trocado a cada 2 ou 3 dias, de acordo com o metabolismo celular, e ao atingir subconfluência, células eram subcultivadas. Amostras representativas da cultura foram congeladas e mantidas em nitrogênio líquido, crioprotegidas com 5-10\% de di-metil sulfóxido (DMSO, Sigma).

\subsubsection{Imunofluorescência para detecção da cadeia $\alpha 1$ da laminina}

Células OSCC foram cultivadas sobre lamínulas de vidro durante 24 horas, na presença de DMEM com $10 \%$ SFB. Após este período, meio de cultura foi removido e anticorpo gerado em coelho contra cadeia $\alpha 1$ da laminina (HK-175), diluído 1/50 em solução de $5 \%$ leite desnatado, $0.1 \mathrm{M} \mathrm{NaCl}, 0.02 \mathrm{M} \mathrm{Na}_{2} \mathrm{HPO}_{4}(\mathrm{pH} 7.4$ ), foi aplicado sobre as amostras durante 1 hora a $4{ }^{\circ} \mathrm{C}$. Em seguida, células foram lavadas em solução de $0.15 \mathrm{M} \mathrm{NaCl}, 0.05 \mathrm{M} \mathrm{Na}_{2} \mathrm{HPO}_{4}(\mathrm{pH} 7.4)$, e fixadas em $3 \%$ paraformaldeído por 20 minutos a temperatura ambiente. Anticorpo secundário anticoelho conjugado ao fluorocromo Alexa-568 (Invitrogen Co., Carlsbad, CA, USA), diluído $1 / 100$ em solução de $0.15 \mathrm{M} \mathrm{NaCl}, 0.05 \mathrm{M} \mathrm{Na}_{2} \mathrm{HPO}_{4}$ (pH 7.4), foi incubado por 1 hora a temperatura ambiente, e lamínulas foram montadas com Prolong (Invitrogen). Amostras foram observadas em microscópio de fluorescência convencional. Substituição do anticorpo primário por soro não específico serviu como controle negativo. 


\subsubsection{Imunofluorescência para detecção de MMP9}

Células OSCC foram cultivadas sobre lamínulas de vidro durante 24 horas, na presença de DMEM com 10\% SFB. Após este período, realizou-se fixação das células com 3\% paraformaldeído por 20 minutos, permeabilização com $0.05 \%$ Triton X-100 (Sigma) em PBS por 5 minutos, e bloqueio com $10 \%$ soro de cabra por 1 hora. Células foram então incubadas com anticorpo monoclonal gerado em camundongo contra MMP9 (IM37L, Calbiochem), diluído 1/250 em solução de PBS e $2 \%$ soro de cabra. Anticorpo secundário anti-camundongo conjugado ao fluorocromo Alexa-568 (Invitrogen), diluído 1/100 em PBS, revelou o anticorpo primário. Todas as incubações com anticorpos foram feitas por 1 hora à temperatura ambiente. $O$ meio de montagem utilizado foi Prolong (Invitrogen), e células foram observadas em microscópio de fluorescência convencional. Substituição do anticorpo primário por soro não específico serviu como controle negativo.

\subsection{Peptídeo bioativo da laminina}

Os peptídeos AG73 (RKRLQVQLSIRT) e "scrambled" AG73SX (RTLRIKQSVRLQ) foram sintetizados pela empresa EZ Biolab (Westfield, IN, USA), possuindo grau de pureza de $98 \%$ (RP-HPLC) e massa molecular confirmada por espectrometria de massa. AG73SX contém os mesmo aminoácidos do AG73 em sequência embaralhada, e foi utilizado como controle nos experimentos.

\subsection{Papel do peptídeo AG73 na atividade migratória de células OSCC}

\subsubsection{Ensaio de "ferida" em monocamada}

Células OSCC foram cultivadas em placas de 24 poços, na presença de DMEM com $10 \%$ SFB, até formarem uma monocamada confluente. Com auxílio de ponteira de pipeta, foi criada uma descontinuidade nesta monocamada, dando origem a uma área livre de células ("ferida"). As monocamadas com "feridas" foram lavadas com DMEM sem soro para remover debris celulares, e posteriormente incubadas com peptídeos AG73 ou "scrambled" AG73SX diluídos em DMEM sem soro $(100 \mu \mathrm{g} / \mathrm{ml})$. 
Pontos de referência foram demarcados no fundo de cada poço da placa, a fim de localizar os campos correspondentes às áreas livres de células. Esse procedimento permitiu a aquisição de imagens de uma mesma área em diferentes intervalos de tempo, utilizando câmera digital acoplada ao microscópio de contraste de fase. Fechamento das "feridas" foi observado em 0, 24 e 48 horas. Áreas livres de células nos grupos tratados e controles foram calculadas utilizando-se o software de domínio público ImageJ (http://rsb.info.nih.gov/ij/). A taxa de migração celular foi avaliada como porcentagem da área livre de células em 0 hora, arbitrariamente marcada como 100\%. Desse modo, o decréscimo percentual da área da "ferida" caracterizou o índice de migração celular. Os ensaios foram realizados em triplicata.

\subsubsection{Ensaio de migração em sistema de câmaras bipartites}

Para complementar os resultados obtidos com o ensaio de "ferida" em monocamada, a migração também foi avaliada utilizando-se sistema de câmaras bipartites de 10 poços (Neuro Probe Inc., Gaithersburg, MD, USA), separadas por membrana de policarbonato contendo poros de $8 \mu \mathrm{m}$ de diâmetro. Para este ensaio, peptídeo AG73 foi diluído em meio sem soro $(100 \mu \mathrm{g} / \mathrm{ml})$ e colocado nos poços da câmara inferior. Como controles utilizamos AG73SX (peptídeo "scrambled") diluído em meio sem soro $(100 \mu \mathrm{g} / \mathrm{ml})$, DMEM sem soro (controle negativo) e DMEM com $10 \%$ SFB (controle positivo). Um total de $10^{5}$ células/poço, ressuspendidas em meio sem soro, foi colocado na câmara superior sobre membrana. As câmaras foram então incubadas por 20 horas a $37^{\circ} \mathrm{C}$ em estufa de $\mathrm{CO}_{2}$. Quando ocorre migração, células atravessam os poros e ficam localizadas na face da membrana voltada para a câmara inferior. Após período de incubação, a membrana foi removida da câmara e sua porção superior, sobre a qual as células foram cultivadas, foi delicadamente raspada para remoção de células que não migraram. Assim, restaram somente células que migraram, localizadas na face inferior da membrana. Essas células foram fixadas em 4\% paraformaldeído em PBS, e coradas com solução de 0,2\% violeta cristal em $20 \%$ metanol. Aquisição de imagens de 7 campos para cada grupo experimental, utilizando câmera digital acoplada ao microscópio (aumento final de 500x), permitiu a determinação do número de células que migraram através de contagem. Os ensaios de migração em sistema de câmaras bipartites foram realizados em triplicata. 


\subsection{Papel do peptídeo AG73 na atividade invasiva de células OSCC}

\subsubsection{Ensaio de invasão em câmaras bipartites}

Para avaliar se AG73 induz fenótipo invasivo em células OSCC, foi empregado o mesmo sistema de câmaras bipartites de 10 poços (Neuro Probe), usando membrana de policarbonato porosa coberta por $5 \mu \mathrm{l}$ de Matrigel (Trevigen Inc., Gaithesburg, MD, USA) na concentração de $14 \mu \mathrm{g} / \mathrm{ml}$. Poços da câmara inferior foram preenchidos com AG73 ou AG73SX (peptídeo "scrambled") diluídos em meio sem soro em diferentes concentrações $(25,100,250,500 \mu \mathrm{g} / \mathrm{ml})$. Poços da câmara inferior preenchidos com meio sem soro ou DMEM com 10\% de SFB serviram como controles negativo e positivo, respectivamente. Células ressuspendidas em meio sem soro $\left(15 \times 10^{4} /\right.$ poço) foram colocadas na porção superior da câmara sobre membrana coberta por Matrigel. A câmara foi então incubada por 40 horas a $37^{\circ} \mathrm{C}$ em estufa de $\mathrm{CO}_{2}$ para que ocorresse digestão do Matrigel e invasão das células da câmara superior para a inferior. A membrana foi removida da câmara, e sua porção superior, sobre a qual as células foram cultivadas, foi delicadamente raspada para remoção de células que não invadiram e restos de Matrigel. Células localizadas na porção inferior da membrana foram fixadas em 4\% paraformaldeído em PBS e coradas com solução de 0,2\% violeta cristal em 20\% metanol. Aquisição de imagens de 7 campos para cada grupo experimental, utilizando câmera digital acoplada ao microscópio (aumento final de 500x), permitiu a determinação do número de células que invadiram através de contagem. Estes ensaios foram realizados em triplicata.

\subsubsection{Zimografia}

Os resultados obtidos no ensaio de invasão estão intimamente relacionados ao processo de digestão do Matrigel, que pode ser mediado por enzimas como as metaloproteinases da matriz (MMPs). Dessa forma, resolvemos estudar as MMPs 2 e 9 secretadas pelas células OSCC para o meio condicionado através da técnica de zimografia.

Para este experimento, células OSCC $\left(1 \times 10^{4}\right)$ foram cultivadas em placas de 6 poços cobertas com concentrações crescentes de AG73 $(25,100,250,500 \mu \mathrm{g} / \mathrm{ml})$ diluído em água MilliQ. Células cultivadas sobre peptídeo "scrambled" nas mesmas concentrações foram usadas como controle. Após 24 horas, células foram lavadas 
em PBS e tiveram seu meio de cultivo trocado por DMEM sem soro, sendo assim mantidas por mais 24 horas em estufa de $\mathrm{CO}_{2}$. Foram então coletados meios condicionados das células OSCC tratadas com AG73 e AG73SX, e a estes foi adicionado coquetel de inibidores de protease (contendo AEBSF, pepstatina, E-64, bestatina, leupeptina e aprotinina, Sigma). Em seguida, amostras foram centrifugadas a $10.000 \mathrm{~g}$ por 10 minutos a $4 \stackrel{\circ}{ } \mathrm{C}$. O sobrenadante foi concentrado $20 \mathrm{x}$ e dialisado em PBS (microconcentradores Microcom 3000D, Millipore Inc, Bedford, MA, USA). Quantificação de proteínas foi feita através do método BCA (Pierce Inc., Rockford, IL, USA). O volume de meio condicionado carregado em cada poço foi estandardizado com base na quantificação protéica realizada, com o intuito de controlar flutuações na secreção de MMPs decorrentes de proliferação celular eventualmente induzida pelo peptídeo.

Amostras de meio condicionado foram então ressuspendidas em tampão de amostra sem agente redutor, contendo $0.3 \mathrm{M}$ Tris- $\mathrm{HCl}, 5 \%$ SDS, $50 \%$ glicerol e corante (Pierce), e carregadas em gel de $10 \%$ de poliacrilamida contendo $0,2 \%$ gelatina. Foram carregados nos géis padrões de pesos moleculares e padrões de MMPs (Sigma), além de 0,10 $\mu \mathrm{g}$ de SFB (controle interno). Após eletroforese, o gel foi lavado em $10 \mathrm{mM}$ Tris ( $\mathrm{pH} 8.0$ ) com 2.5\% Triton $\mathrm{X}-100$ por 30 minutos para remoção de SDS e renaturação das proteínas. Em seguida, o gel foi incubado por 20 horas a $37^{\circ} \mathrm{C}$ em solução tampão revelador de gel (50 mM Tris pH 8.8, $150 \mathrm{mM}$ $\mathrm{NaCl}, 5 \mathrm{mM} \mathrm{CaCl}_{2}$ ). Os géis foram então corados com $0.2 \%$ Comassie blue (Amersham Co, Arlington Heights, IL, USA) e descorados em solução de $40 \%$ metanol e 10\% ácido acético glacial em água destilada. Após essa etapa, as metaloproteinases ativas foram identificadas no gel como bandas claras de lise em fundo azul.

As bandas de degradação enzimática obtidas na zimografia foram comparadas por densitometria do gel, utilizando-se o programa de domínio público ImageJ (http://rsb.info.nih.gov/ij/). Os dados densitométricos obtidos foram normalizados e expressos como porcentagem da densitometria das bandas de soro fetal bovino (controle interno). Os experimentos de zimografia foram realizados em triplicata e repetidos pelo menos duas vezes.

Controles negativos foram realizados para confirmar se bandas de lise eram resultado da ação de metaloproteinases da matriz. Dois outros géis, contendo as mesmas amostras descritas anteriormente, foram incubados com tampão revelador 
contendo $5 \mathrm{mM} \mathrm{1,10} \mathrm{fenantrolina} \mathrm{(quelante} \mathrm{de} \mathrm{metais} \mathrm{pesados)} \mathrm{ou} 10 \mathrm{mM}$ EDTA (quelante de cálcio). Os quelantes inibem a ação das MMPs e, consequentemente, bloqueiam a formação das bandas de lise descritas.

\subsection{Estudo de receptores envolvidos nas atividades mediadas por AG73 em células OSCC}

\subsubsection{Colocalização dos receptores sindecana-1 e integrina $\beta 1$}

Dados obtidos em nosso Laboratório demonstraram que sindecana-1 e integrinas podem estar relacionados à transdução de sinais gerados por peptídeos bioativos da laminina (FREITAS et al., 2007; GAMA-DE-SOUZA et al., 2008). Por tal motivo, resolvemos investigar a presença destes receptores nas células OSCC.

Para este estudo, células ressuspendidas em DMEM sem soro foram cultivadas por 6 horas sobre lamínulas de vidro cobertas com AG73 ou AG73SX diluídos em água MilliQ (100 $\mu \mathrm{g})$. Após este período, meio de cultura foi removido e células foram incubadas por 1 hora a $4 \stackrel{\circ}{\mathrm{C}} \mathrm{com}$ anticorpo monoclonal produzido em camundongo contra sindecana-1 (CBL 588, Chemicon Co, Temecula, CA, USA), diluído $1 / 100$ em solução de $5 \%$ leite desnatado, $0.1 \mathrm{M} \mathrm{NaCl}$, $0.02 \mathrm{M} \mathrm{Na}_{2} \mathrm{HPO}_{4}(\mathrm{pH}$ 7.4). Em seguida, células foram lavadas em solução de $0.15 \mathrm{M} \mathrm{NaCl}, 0.05 \mathrm{M}$ $\mathrm{Na}_{2} \mathrm{HPO}_{4}$ ( $\mathrm{pH}$ 7.4), e fixadas em $3 \%$ paraformaldeído por 20 minutos a temperatura ambiente. Anticorpo secundário anti-camundongo conjugado ao fluorocromo Alexa568 (Invitrogen), diluído 1/100 em solução de $0.15 \mathrm{M} \mathrm{NaCl}, 0.05 \mathrm{M} \mathrm{Na}_{2} \mathrm{HPO}_{4}(\mathrm{pH}$ 7.4), revelou o anticorpo primário contra sindecana-1. Células foram então permeabilizadas com $0.05 \%$ Triton X-100 (Sigma) por 2 minutos, e incubadas com anticorpo policlonal produzido em coelho contra integrina $\beta 1$ (AB1952, Chemicon), diluído $1 / 100$ em solução de $5 \%$ leite desnatado, $0.1 \mathrm{M} \mathrm{NaCl}, 0.02 \mathrm{M} \mathrm{Na}_{2} \mathrm{HPO}_{4}(\mathrm{pH}$ 7.4). Anticorpo secundário anti-coelho conjugado ao fluorocromo Alexa-488 (Invitrogen), diluído $1 / 100$ em solução de $0.15 \mathrm{M} \mathrm{NaCl}, 0.05 \mathrm{M} \mathrm{Na}_{2} \mathrm{HPO}_{4}$ (pH 7.4), revelou anticorpo primário contra integrina $\beta 1$. Todas as incubações de anticorpos, exceto contra sindecana-1, foram realizadas a temperatura ambiente, por 1 hora. $\mathrm{O}$ meio de montagem utilizado foi Prolong (Invitrogen). 
$\mathrm{Na}$ análise de colocalização, feita em microscópio de fluorescência convencional, um mínimo de 50 células foi observado, e os resultados repetiram-se consistentemente.

\subsubsection{RNA de Interferência}

Buscando uma maior compreensão sobre componentes envolvidos nos processos de sinalização mediados por AG73, realizamos ensaios com células silenciadas com RNA de interferência (RNAi). Para isso, obtivemos comercialmente RNAi para sindecana-1 e integrina $\beta 1$ (Santa Cruz Biotechnology Inc., Santa Cruz, CA, USA).

Células OSCC foram cultivadas em placas de 6 poços até atingirem $50 \%$ de confluência. A seguir, meio de transfecção (Optimen, Invitrogen), reagente de transfecção (Lipofectamina 2000, Invitrogen) e RNAi de interesse, na concentração de $50 \mathrm{nM}$, foram misturados e incubados a temperatura ambiente por 30 minutos, de acordo com instruções do fabricante. Esta solução foi adicionada às células OSCC, que foram assim mantidas por um período de 30 horas a $37^{\circ} \mathrm{C}$. Como controle, outro grupo de células foi transfectado com $50 \mathrm{nM}$ de RNAi de sequência "scrambled" (composição de propriedade da Santa Cruz), que não induz degradação de qualquer mensagem celular. Após o período de incubação, células transfectadas com RNAi para sindecana-1, integrina $\beta 1$ e "scrambled" (controle) foram colhidas das placas e submetidas a técnica de "immunoblot", e a ensaios de migração e invasão em câmaras bipartites na presença de AG73 e AG73SX.

\subsection{3 "Immunoblot"}

A técnica de "immunoblot" foi realizada para observar se tratamento com RNAi para sindecana-1 e integrina $\beta 1$ diminuiu a expressão desses dois receptores nas células OSCC. Para tanto, células transfectadas com RNAi para sindecana-1, integrina $\beta 1$ e controle foram lisadas em tampão RIPA (150mM NaCl, $1 \%$ NP-40, $0.5 \%$ deoxicolato, $0.1 \%$ SDS, $50 \mathrm{mM}$ Tris $\mathrm{pH} 8.0$ ) contendo inibidores de protease (pepstatina A, PMSF e E-64, Sigma). Amostras foram centrifugadas a $10.000 \mathrm{~g}$ por 10 minutos a $4{ }^{\circ} \mathrm{C}$, e o sobrenadante recolhido. Quantificação de proteínas foi feita através do método BCA (Pierce). 
Eletroforese foi realizada seguindo protocolo para SDS-PAGE. Amostras foram ressuspendidas em tampão de amostra (3\% dodecil sulfato de sódio, $150 \mathrm{mM}$ Tris $\mathrm{pH} 6.8,15 \%$ mercaptoetanol, 30\% glicerol, 0,01\% azul de bromofenol) e carregadas em gel de poliacrilamida 10\% (preparado com $1.5 \mathrm{M}$ Tris- $\mathrm{HCl}, 10 \%$ SDS, $30 \%$ bis-acrilamida, 10\% persulfato de amônia e TEMED). Após eletroforese, proteínas foram transferidas para membranas de nitrocelulose (Amersham), que posteriormente foram bloqueadas com $5 \%$ leite desnatado em $0.05 \%$ Tween-20 em TBS (TTBS), e incubadas com anticorpos contra sindecana-1 (policlonal gerado em coelho, sc-5632, Santa Cruz), integrina $\beta 1$ (policlonal gerado em coelho, AB1953, Chemicon) e $\beta$-actina (monoclonal gerado em camundongo, Sigma). Esses anticorpos primários foram detectados por anticorpos secundários conjugados com peroxidase (Amersham). Protocolo de quimioluminescência (ECL kit, Amersham) foi utilizado para revelar a reação em filmes radiográficos. Para possibilitar marcação com diferentes anticorpos, as membranas foram "stripped" com "Restore Western Blot Stripping Buffer" (Pierce) e submetidas a novas marcações.

Nas amostras controles e tratadas com RNAi, a eficiência da transfecção foi analisada pela diminuição na expressão dos receptores, quando comparada ao controle interno de $\beta$-actina.

\subsubsection{Ensaio de migração (células silenciadas para sindecana-1 e integrina $\beta 1$ )}

O efeito do silenciamento de receptores na migração de células OSCC induzidas por AG73 foi avaliado através de ensaio em sistema de câmaras bipartites de 10 poços (Neuro Probe). Para este ensaio, células OSCC tiveram os receptores sindecana-1 e integrina $\beta 1$ silenciados por RNAi conforme descrito anteriormente, não havendo dupla transfecção. Como controle foi utilizado RNAi de sequência "scrambled".

Após período de tratamento com RNAi, células foram tripsinizadas, contadas e cultivadas na presença de AG73 ou AG73SX (100 $\mu \mathrm{g} / \mathrm{ml})$. Células transfectadas com RNAi controle foram ainda cultivadas na presença de DMEM sem soro (controle negativo) e DMEM com 10\% SFB (controle positivo). O ensaio foi realizado conforme descrito anteriormente, e as câmaras foram incubadas por 20 horas a $37^{\circ} \mathrm{C}$ em estufa de $\mathrm{CO}_{2}$. A membrana foi então removida da câmara e sua porção superior, sobre a qual as células foram cultivadas, foi raspada para remoção de células que 
não migraram. Células que migraram, localizadas na face inferior da membrana foram fixadas em $4 \%$ paraformaldeído em PBS, e coradas com $0,2 \%$ violeta cristal em $20 \%$ metanol. Aquisição de imagens de 7 campos das membranas (aumento final de 500x), permitiu a determinação do número de células que migraram através de contagem. Estes ensaios foram realizados em triplicata.

\subsubsection{Ensaio de invasão (células silenciadas para sindecana-1 e integrina $\beta 1$ )}

Para analisar o efeito do silenciamento de receptores $\beta 1$ no fenótipo invasivo induzido por AG73, utilizamos sistema de câmaras bipartites de 10 poços (Neuro Probe), com membrana de policarbonato porosa coberta por $5 \mu$ de Matrigel (Trevigen). Neste experimento, células OSCC tiveram os receptores sindecana-1 ou integrina $\beta 1$ silenciados por RNAi conforme descrito anteriormente, não havendo dupla transfecção. Como controle foi utilizado RNAi de sequência "scrambled".

Após período de tratamento com RNAi, células foram tripsinizadas, contadas e cultivadas na presença de AG73 ou AG73SX (100 $\mu \mathrm{g} / \mathrm{ml})$. Células transfectadas com RNAi controle foram ainda cultivadas na presença de DMEM sem soro (controle negativo) e DMEM com 10\% SFB (controle positivo). O ensaio foi realizado conforme descrito anteriormente, e as câmaras foram incubadas por 40 horas a $37^{\circ} \mathrm{C}$ em estufa de $\mathrm{CO}_{2}$. Membrana foi então removida da câmara e sua porção superior, sobre a qual as células foram cultivadas, foi raspada para remoção de células que não invadiram e restos de Matrigel. Células invasivas, localizadas na face inferior da membrana, foram fixadas em $4 \%$ paraformaldeído em PBS, e coradas com 0,2\% violeta cristal em $20 \%$ metanol. Aquisição de imagens de 7 campos das membranas (aumento final de 500x), permitiu a determinação do número de células que invadiram através de contagem. Estes ensaios foram realizados em triplicata.

\subsection{Análise Estatística}

Dados obtidos a partir dos experimentos foram analisados usando o software GraphPad Prism 5 (GraphPad Software Inc., San Diego, CA, USA). Teste t de Student foi utilizado para avaliar diferenças entre dois grupos. Diferenças entre três ou mais grupos foram estimadas através de análise de variância (ANOVA), seguido por teste de comparações múltiplas de Bonferroni. 


\section{RESULTADOS}

\subsection{Carcinoma epidermóide oral expressam a cadeia $\alpha 1$ da laminina e MMP9 in vivo e in vitro}

O peptídeo AG73 está presente na cadeia $\alpha 1$ da laminina, e pode depender de proteólise mediada por MMPs para ser liberado e disponibilizado para as células (NOMIZU et al., 1995; GHOSH e STACK, 2000; FAISAL KHAN et al., 2002). Por tal motivo, resolvemos investigar a expressão da cadeia $\alpha 1$ da laminina e MMP9 no carcinoma epidermóide.

Em amostras de carcinoma epidermóide oral incluídas em parafina, células neoplásicas apresentaram proeminente expressão citoplasmática da cadeia $\alpha 1$ da laminina, principalmente em sítios e cordões de invasão (Fig. 1A). MMP9 foi observada tanto nas células neoplásicas quanto no estroma.(Fig. 1 B, C). Controle negativo não exibiu marcação (Fig. 1D).

Em linhagem celular derivada de carcinoma epidermóide (células OSCC), cadeia $\alpha 1$ da laminina foi expressa como pontos distribuídos sobre a membrana celular (Fig. 2A). Marcação para laminina representa distribuição desta proteína na membrana celular, uma vez que as amostras não foram permeabilizadas. Células OSSC exibiram marcação pontual intracelular para MMP9 (Fig. 2B). Controle negativo não exibiu marcação (dado não ilustrado).

\subsection{O peptídeo AG73 influencia atividade migratória de células OSCC}

Ensaios para análise de migração mostraram que AG73 promove aumento da atividade migratória de células OSCC. Ensaio de "ferida" em monocamada (Fig. 3A) mostrou que células OSCC tratadas com peptídeo AG73 apresentaram maior índice de migração, quando comparadas a células controles crescidas na presença do peptídeo "scrambled" AG73SX. Após 24 horas, células OSCC cultivadas na presença de AG73 exibiam $25 \%$ de área livre de células, enquanto células tratadas com AG73SX ainda apresentavam 75\% de área livre. Após 48 horas, apenas $8 \%$ de área livre de células foi observada no grupo tratado com AG73, comparada a $70 \%$ no controle (Fig. 3A, gráfico). 
Ensaios de migração realizados em câmaras bipartites por 20 horas confirmaram resultados obtidos no ensaio de "ferida" em monocamada. Células OSCC tratadas com AG73 tiveram aumento de 3x na taxa de migração celular, quando comparadas a células cultivadas na presença de AG73SX (Fig. 3B). Ensaios de "ferida" e de migração foram realizados pelo menos três vezes, apresentando resultados semelhantes.

\subsection{Peptídeo AG73 influencia atividade de invasão e secreção de MMPs em células OSCC}

Ensaios de invasão em câmaras bipartites com membrana porosa coberta por Matrigel mostraram que AG73 estimulou aumento da atividade invasiva de células OSCC, quando comparadas aos controles com peptídeo "scrambled" (Fig. 4A). Além do mais, o aumento da concentração de peptídeos promoveu aumento da taxa de invasão, evento que não foi observado em células tratadas com peptídeo scrambled.

Invasão de células tumorais para o tecido conjuntivo circunjacente envolve atividade de metaloproteinases da matriz (MMPs) (PAGE-MCCAW et al., 2007). Para verificar se invasão estimulada por AG73 estaria relacionada com proteases, amostras de meio condicionado de células OSCC cultivadas sobre AG73 e AG73SX foram submetidas à zimografia. Géis contendo essas amostras exibiram bandas gelatinolíticas com pesos moleculares correspondentes a MMPs 2 e 9. Controles positivos para estas MMPs corridos no mesmo gel confirmaram os resultados (Fig. 4B, gel). Obtivemos com este ensaio a resolução de bandas das MMPs 2 e 9. Células crescidas tanto na presença de AG73 como AG73SX secretaram MMPs. No entanto, observa-se que somente AG73 induziu aumento dose dependente de MMP9 ativa (Fig. 4B, gel). Densitometria das bandas gelatinolíticas, feita através do software ImageJ e expressa como porcentagem das bandas de MMPs de soro fetal bovino (controle interno), mostrou que AG73 promoveu aumento dose dependente de MMP9, quando comparado ao AG73SX (Fig. 4B, gráfico).

Para determinar se as bandas visualizadas no gel seriam resultado da atividade de MMPs, géis controles contendo meio condicionado de células tratadas com AG73 foram incubados na presença de quelantes de cálcio (EDTA) e metais pesados ( 1,10 fenantrolina). Ambos tratamentos resultaram em perda da atividade de gelatinases, demonstrando que bandas de lise observadas eram MMPs (dado 
não ilustrado). Ensaios de invasão e zimografia foram realizados pelo menos três vezes, com resultados semelhantes.

\subsection{Sindecana-1 e integrina $\beta 1$ participam dos processos de migração e invasão induzidos por AG73 em células OSCC}

Para compreender os mecanismos regulatórios que podem participar dos processos de migração e invasão induzidos por AG73, decidimos estudar possíveis receptores celulares para este peptídeo em células OSCC. Sindecana-1 já foi identificada como ligante de AG73 (HOFFMAN et al., 1998; HOZUMI et al., 2006). Além disso, sindecana-1 e integrina $\beta 1$ já foram caracterizadas em nosso laboratório como reguladores chave das atividades de migração, invasão e atividade de protease em células derivadas de neoplasias de glândulas salivares (GAMA-DESOUZA et al., 2008)

Com base nestes dados, resolvemos detectar a presença desses dois receptores na linhagem OSCC, através de imunofluorescência. Observamos expressão de sindecana-1 e integrina $\beta 1$ em células cultivadas tanto sobre lamínulas cobertas com AG73 (Fig. 5 A,B) quanto com AG73SX (Fig. 5 D,E). O peptídeo AG73 induziu ainda distribuição polarizada e colocalização de sindecana-1 e integrina $\beta 1$ (Fig. $5 \mathrm{C}$ ). Células tratadas com peptídeo controle AG73SX não exibiram colocalização destes receptores (Fig. 5 F).

Passamos a analisar então se sindecana-1 e integrina $\beta 1$ estariam relacionados a atividades induzidas por AG73. Para isso, esses dois receptores foram silenciados em células OSCC, através de transfecção com RNAi.

A eficácia de silenciamento dessas proteínas foi inicialmente confirmada através de "immunoblot", onde observamos que células tratadas com RNAi para sindecana-1 e integrina $\beta 1$ exibiram diminuição da expressão desses receptores, quando comparadas a células transfectadas com RNAi controle (Fig. 6C)

Células OSCC com reduzida expressão sindecana-1 e integrina $\beta 1$ foram submetidas a ensaios de migração e invasão, na presença de AG73 e AG73SX, por 20 e 40 horas respectivamente. Silenciamento dos receptores promoveu diminuição significante das atividades migratória (Fig. 6A) e invasiva (Fig. 6B) induzidas por AG73, quando comparadas com células tratadas com RNAi controle. Não houve diferença significativa entre grupos de células transfectadas com RNAi para 
sindecana-1, integrina $\beta 1$ e controle tratadas com AG73SX. Estes ensaios foram realizados pelo menos três vezes, com resultados semelhantes. 
Figura 5.1

=




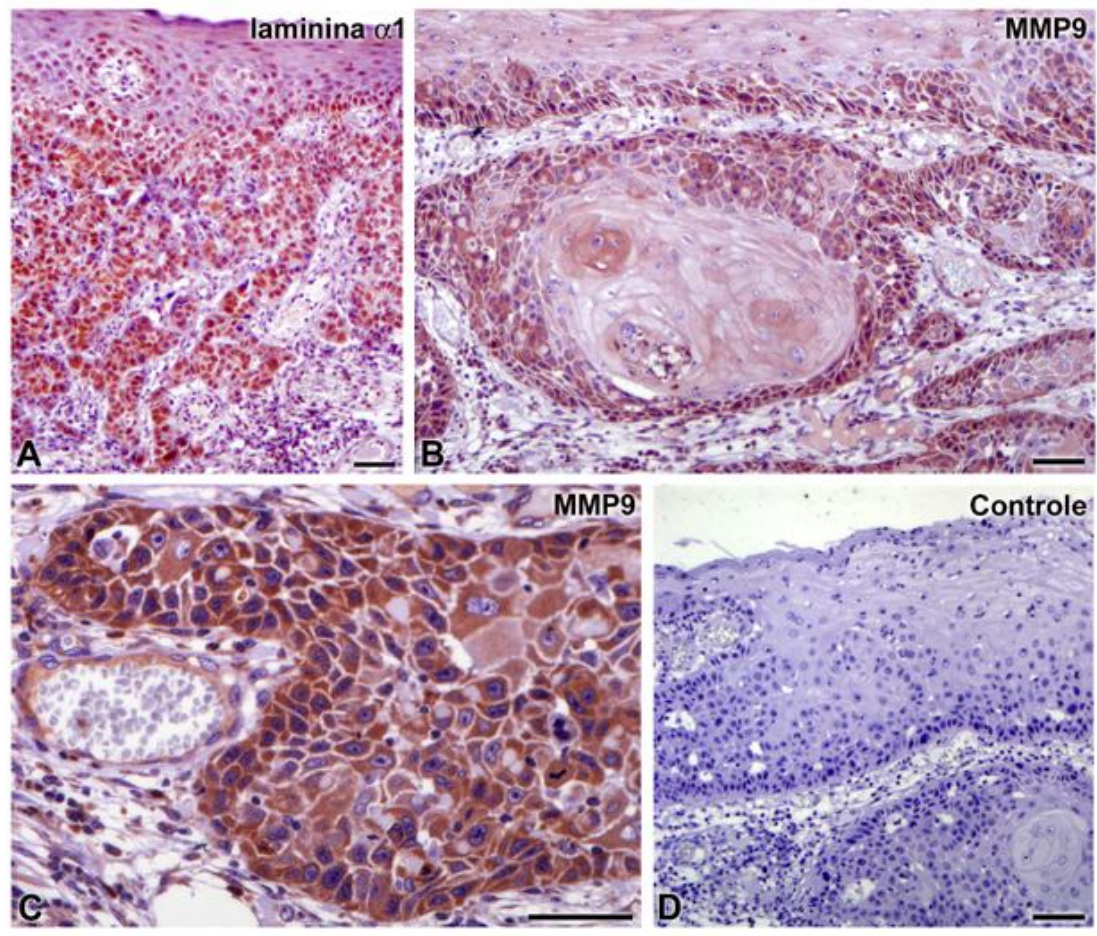

Fig. 1

Figura 1. Cadeia $\alpha 1$ da laminina-111 e MMP9 estão expressas em carcinoma epidermóide oral in vivo. Expressão da cadeia $\alpha 1$ da laminina é observada no citoplasma de células neoplásicas localizadas em cordões de invasão (A). MMP9 está imunolocalizada no citoplasma de células do carcinoma epidermóide e em algumas células do estroma ( $B$, C). Controles negativos não exibem marcação (D). Escala: $50 \mu \mathrm{m}$. 
Figura 5.2

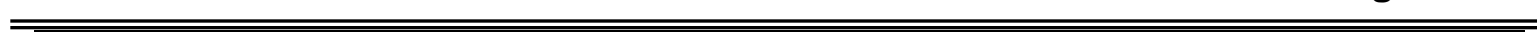



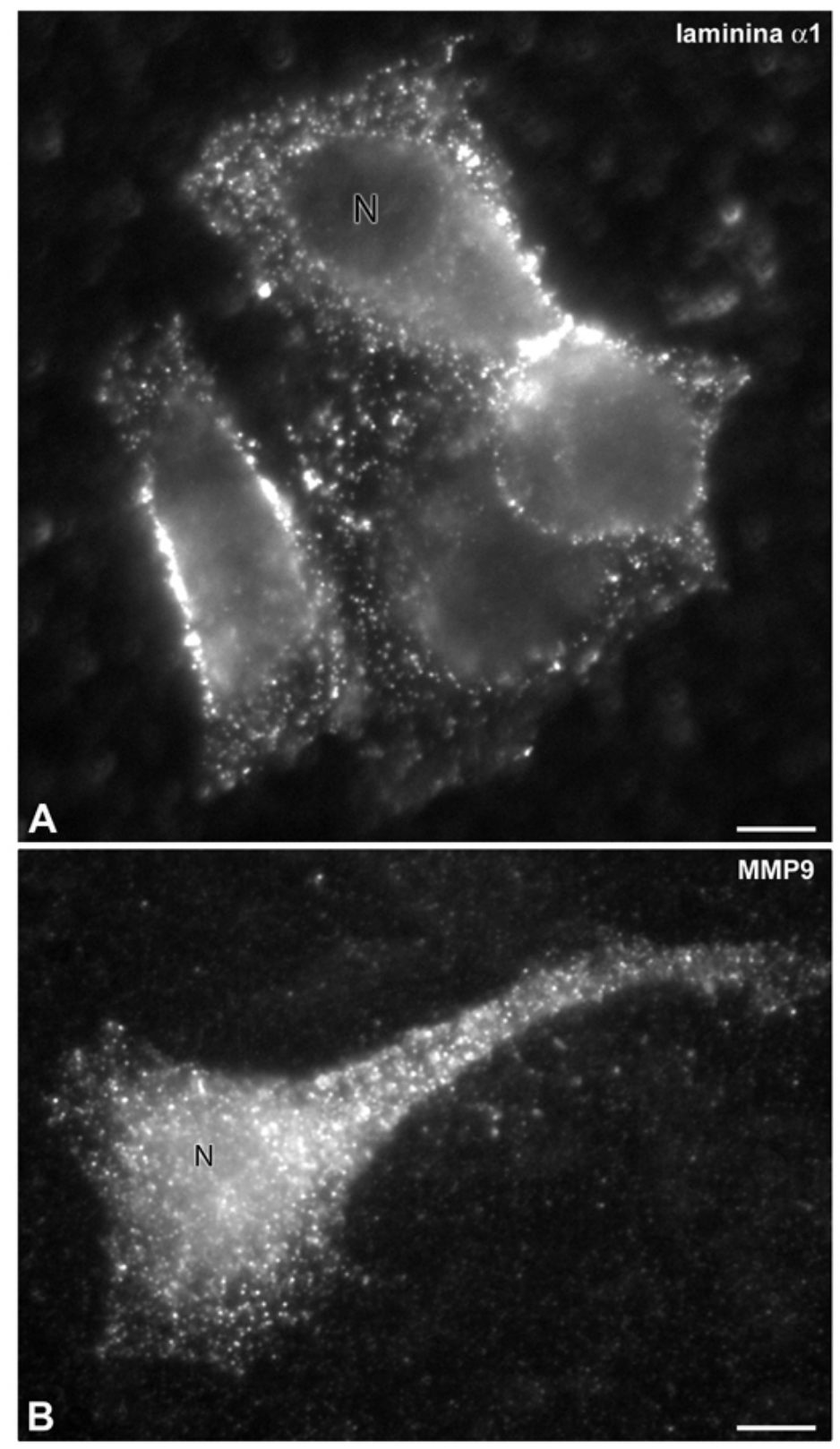

Fig. 2

Figura 2. Cadeia $\alpha 1$ da laminina-111 e MMP9 estão expressas em carcinoma epidermóide oral in vitro. Em linhagem celular derivada de carcinoma epidermóide oral (OSCC), cadeia $\alpha 1 \mathrm{da}$ laminina é observada como pontos distribuídos sobre a membrana celular (A). MMP9 é visualizada como marcação puntiforme no citoplasma de células OSCC (B). Marcação para MMP9 também é observada no espaço extracelular, o que pode representar secreção desta enzima. Escala: $20 \mu \mathrm{m}$. 
Figura 5.3

=




\section{A - Ensaio de "Ferida" em Monocamada}

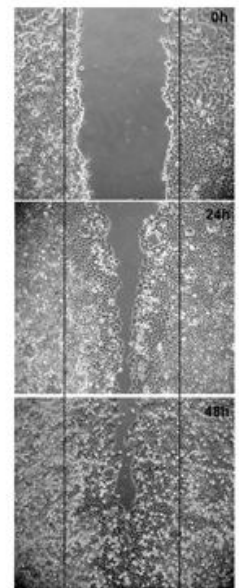

AG73

$(100 \mu \mathrm{g} / \mathrm{ml})$

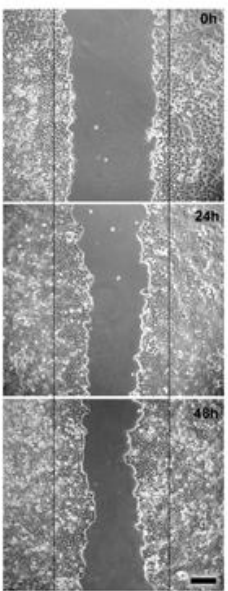

AG73SX

$(100 \mu \mathrm{g} / \mathrm{ml})$

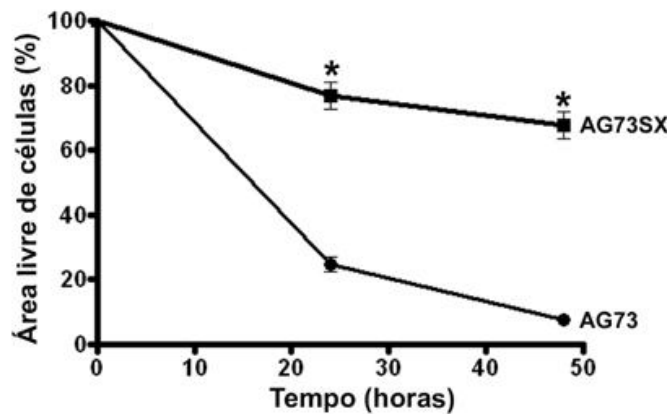

\section{B - Ensaio de Migração}

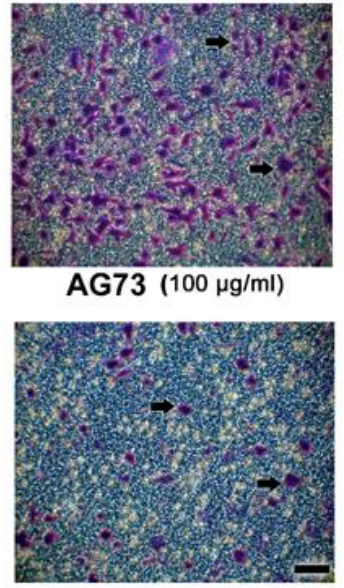

AG73SX $(100 \mu \mathrm{g} / \mathrm{ml})$

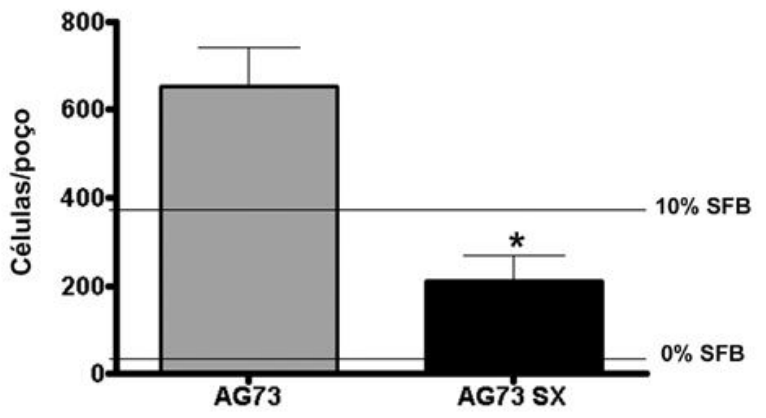

Fig. 3

Figura 3. AG73 induz migração em células OSCC. No ensaio de "ferida" (A), microscopia de contraste de fase mostra que área de descontinuidade em monocamada de células tratada com AG73 está quase totalmente fechada após 48h, enquanto no grupo controle esta área é de aproximadamente $70 \%$ (A, painel esquerdo). Resultados em A são confirmados por medições das áreas livres de células no decorrer do tempo ( $A$, gráfico). No ensaio de migração (B), fotomicrografias de campos da membrana mostram que mais células (setas) migraram no grupo tratado com AG73 que com AG73SX (B, painel esquerdo). Contagem de células revelou que taxa de migração na presença de AG73 é 3x maior que a de AG73SX (B, gráfico). Linhas horizontais em $B$ representam número de células/poço em grupos tratados com 10\% SBF (controle positivo) e 0\% SBF (controle negativo). Asteriscos indicam dados estatisticamente significantes $(\mathrm{P}<0.05)$. Resultados representam média \pm erro da média de três experimentos realizados pelo menos três vezes. Escala: $50 \mu \mathrm{m}$. 
Figura 5.4

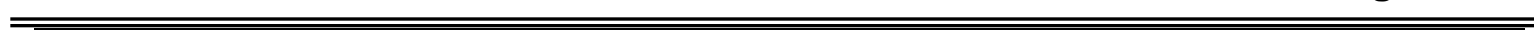


A - Ensaio de Invasão

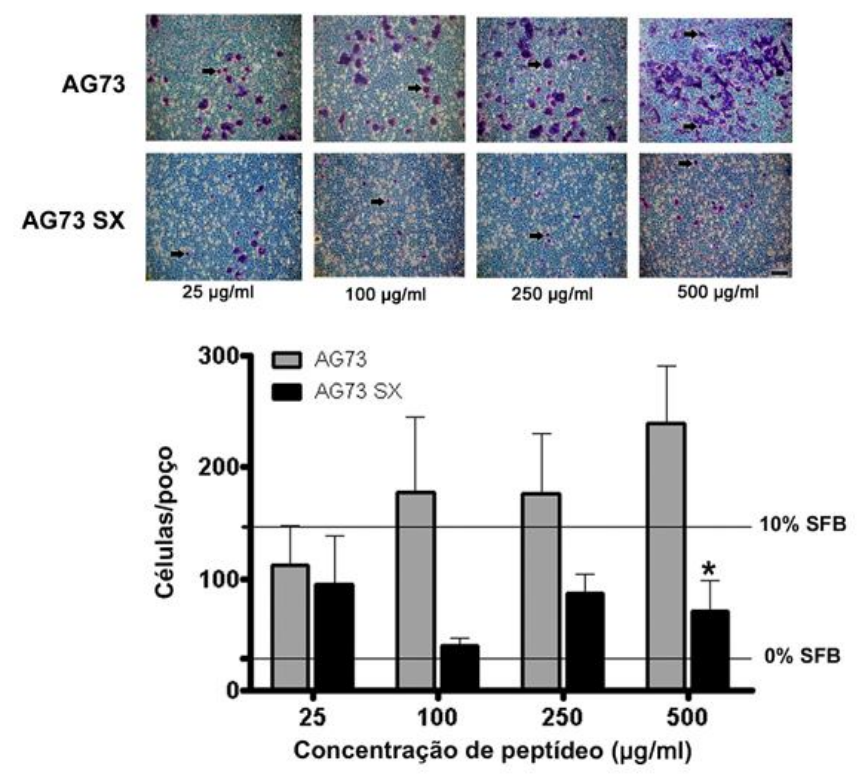

B - Zimografia
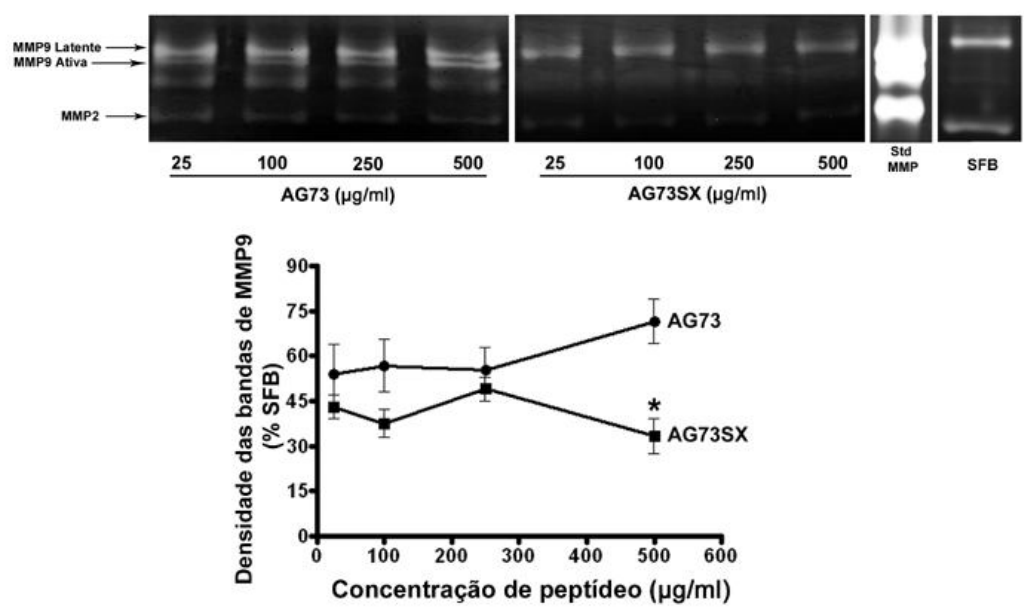

Fig. 4

Figura 4. AG73 aumenta invasão e atividade de MMP9 em células OSCC. No ensaio de invasão (A), fotomicrografias de campos da membrana mostram que mais células (setas) invadiram nos grupos tratados com AG73 que com AG73SX em todas as concentrações (A, painel superior). Contagem de células revelou que houve aumento dose-dependente na taxa de invasão na presença de AG73 (A, gráfico). Meio condicionado de células OSCC cultivadas sobre AG73 ou AG73SX foi analisado por zimografia (B). Bandas gelatinolíticas correspondentes às formas latente e ativa de MMP9 e à MMP2 foram observadas. Controles interno (SBF) e positivo para MMPs 2 e 9 (Std MMP) estão incluídos ( $B$, painel superior). Densitometria das bandas mostra que houve aumento dose-dependente de MMP9 ativa em células tratadas com AG73 (B, gráfico). Linhas horizontais em A representam número de células/poço em grupos tratados com 10\% SBF (controle positivo) e $0 \%$ SBF (controle negativo). Asteriscos indicam dados estatisticamente significantes $(P<0.05)$. Resultados representam média \pm erro da média de três experimentos realizados pelo menos três vezes. Escala: $50 \mu \mathrm{m}$. 
Figura 5.5

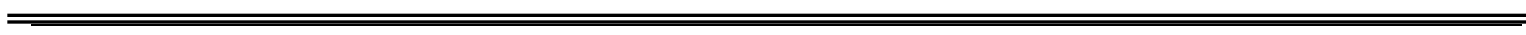



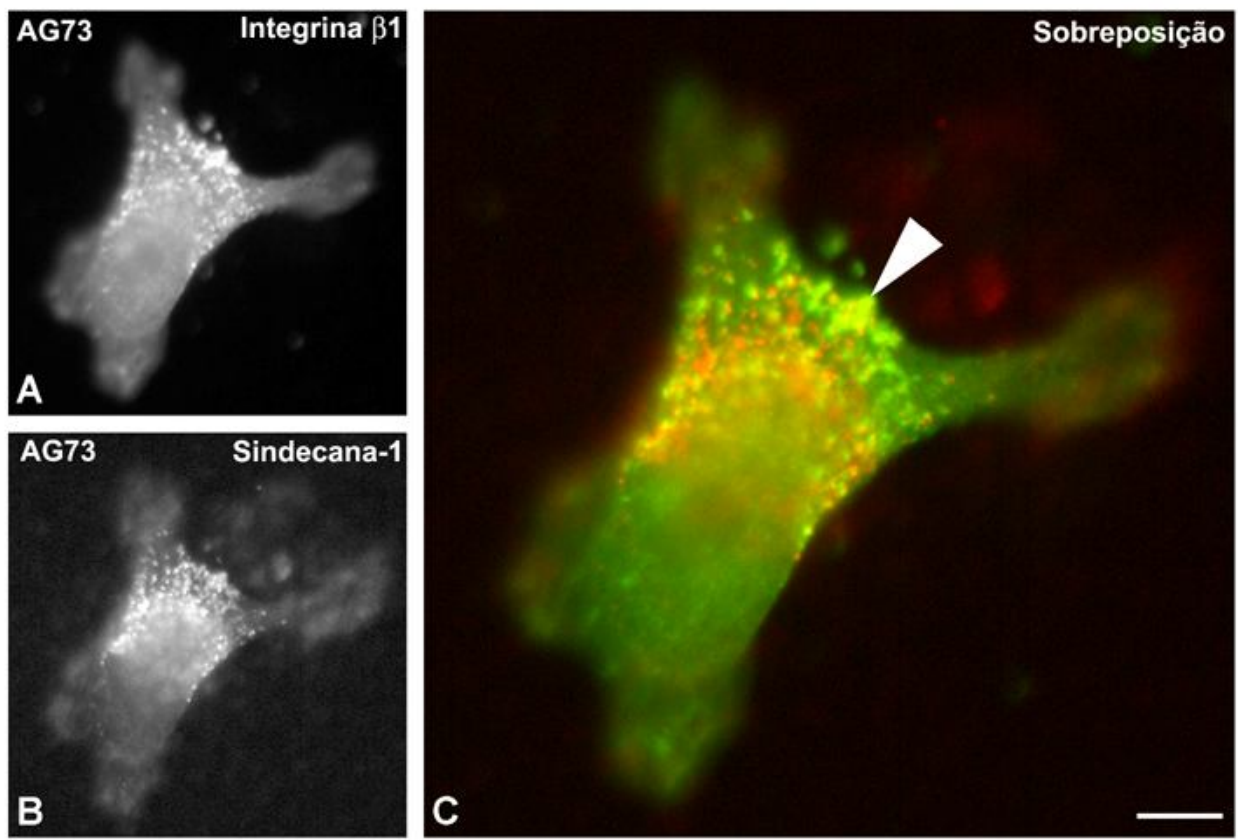

B

Sindecana-1

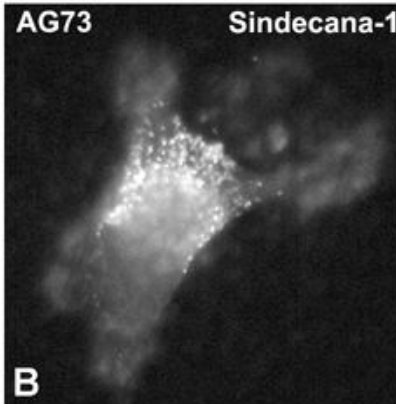

Sobreposição
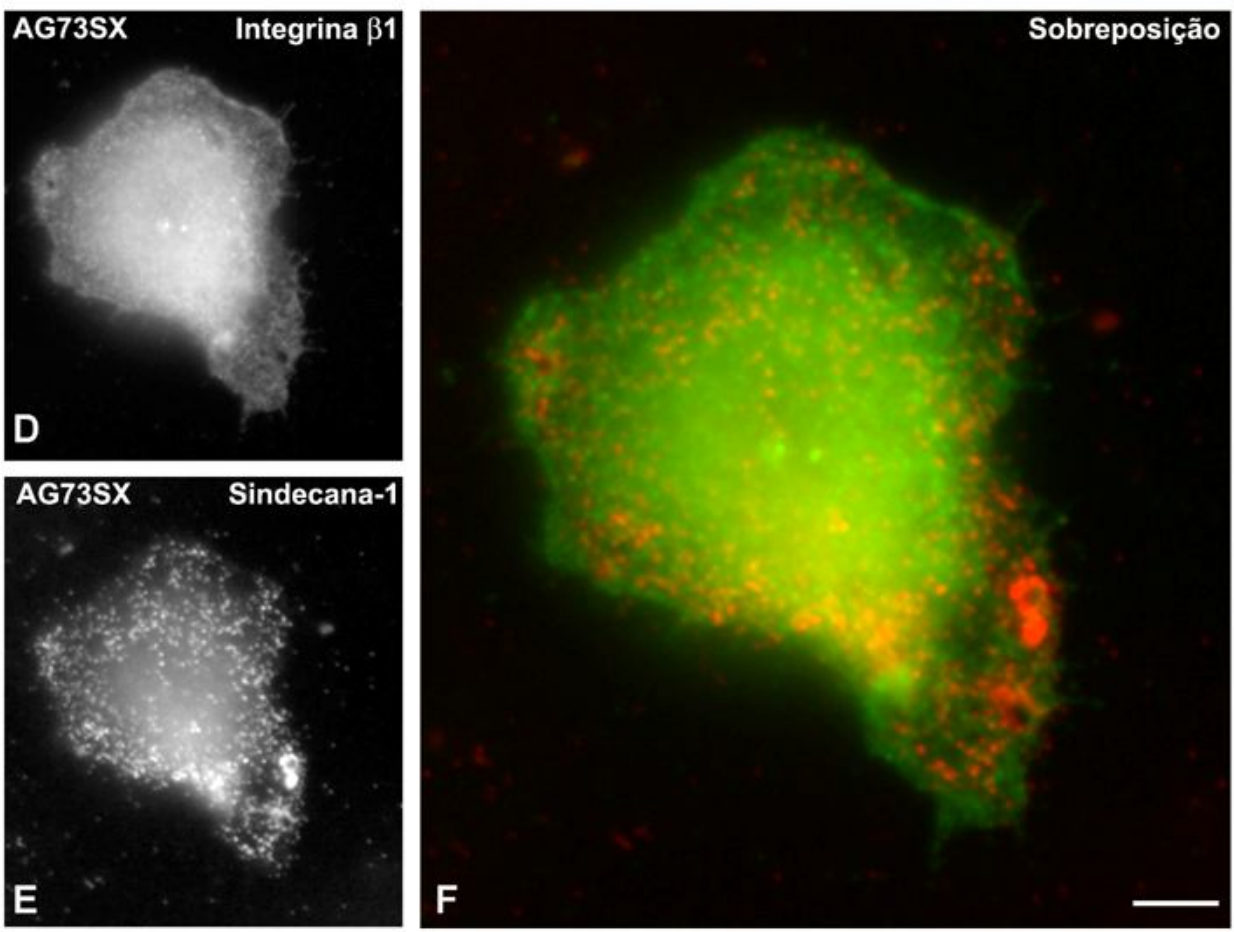

Fig. 5

Figura 5. Sindecana-1 e integrina $\beta 1$ estão colocalizadas em células OSCC na presença de AG73. Células cultivadas sobre AG73 ou AG73SX exibem marcação para integrina $\beta 1$ (A e D) e sindecana-1 ( $B$ e E). Sobreposições em $C$ e $F$ exibem pontos verdes (integrina $\beta 1$ ) e vermelhos (sindecana-1). AG73 induz colocalização e distribuição polarizada de integrina $\beta 1$ e sindecana-1 em células OSCC (C, amarelo, cabeça de seta). Células tratadas com peptídeo controle (AG73SX) não exibiram colocalização desses receptores (F). Escalas: $20 \mu \mathrm{m}$. 
Figura 5.6

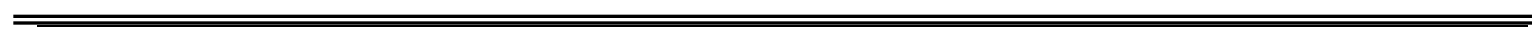




\section{A - Ensaio de Migração}

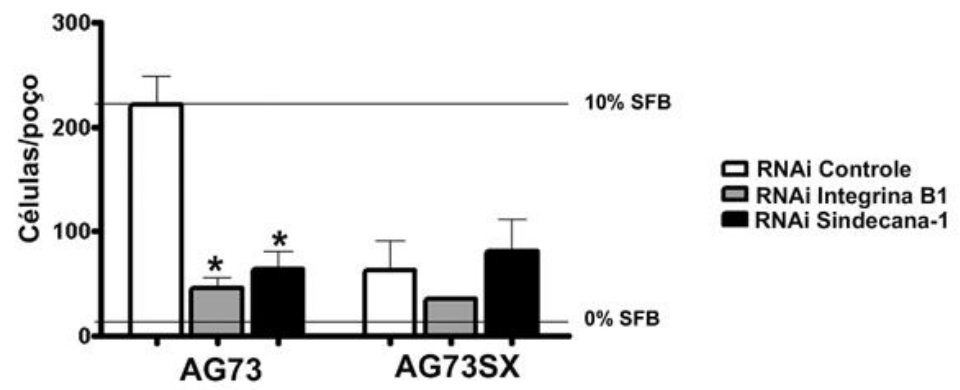

\section{B - Ensaio de Invasão}

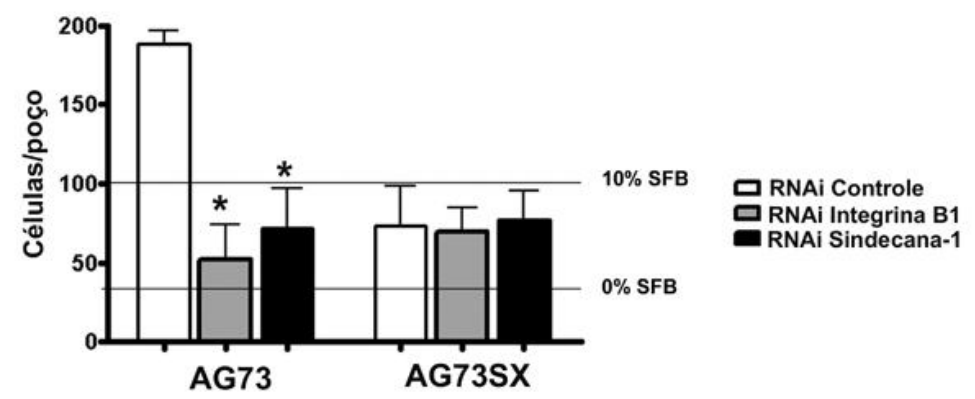

\section{C - "Immunoblot"}
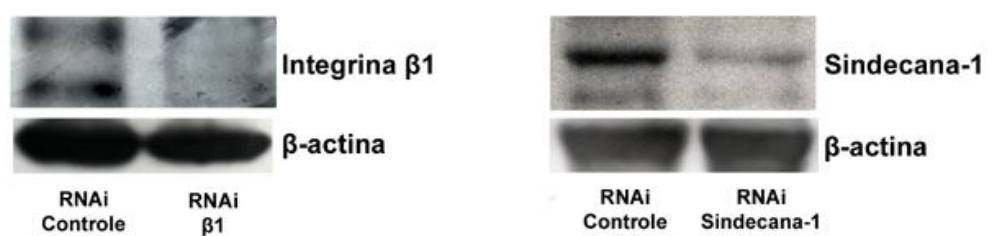

Fig. 6

Figura 6. Silenciamento de sindecana-1 e integrina $\beta 1$ em células OSCC mostra que esses receptores regulam migração e invasão induzidas por AG73. Como esperado, células transfectadas com RNAi controle e tratadas com AG73 exibem altas atividades migratória e invasiva (A e B, colunas brancas do grupo AG73). Por outro lado, células com sindecana-1 ou integrina $\beta 1$ silenciadas exibem decréscimo na migração e invasão ( $A$ e $B$, colunas cinzas e pretas do grupo AG73). Diferenças não foram encontradas nas atividades migratória e invasiva de células OSCC com receptores silenciados e crescidas em AG73SX (A e B, colunas do grupo AG73SX). "Immunoblot" confirma eficácia de transfecção do RNAi $(C)$. Linhas horizontais em $A$ e $B$ representam número de células/poço em grupos de células transfectadas com RNAi controle e tratadas com 10\% SBF (controle positivo) e 0\% SBF (controle negativo). Asteriscos indicam dados estatisticamente significantes $(P<0.05)$. Resultados representam média \pm erro da média de três experimentos realizados pelo menos três vezes. 


\section{DISCUSSÃO}

Os resultados deste trabalho mostram que a cadeia $\alpha 1$ da laminina-111 e MMP9 estão expressas no carcinoma epidermóide oral in vivo e in vitro. Essa cadeia contém o peptídeo AG73, localizado no domínio globular LG4. AG73 estimulou atividades de migração, além de invasão e secreção de MMP9 dose-dependentes em linhagem celular derivada de carcinoma epidermóide humano (células OSCC). Também analisamos possíveis receptores envolvidos nos eventos biológicos induzidos por AG73. Verificamos que células OSCC apresentaram colocalização de sindecana-1 e integrina $\beta 1$ quando crescidas sobre AG73. Silenciamento desses dois receptores por RNA de interferência promoveu redução na migração e invasão de células OSCC crescidas na presença de AG73. Esses resultados sugerem que sindecana-1 e integrina $\beta 1$ podem participar da transdução de sinais gerados por AG73 e participar da regulação de eventos relacionados a esse peptídeo em células OSCC. Analisando a literatura, esse é o primeiro relato em que se estabeleceu o papel de um peptídeo derivado da laminina em carcinoma epidermóide, prevalente tumor da cavidade oral.

Durante muito tempo, as células neoplásicas foram o alvo de muitos estudos relacionados ao câncer. Contudo, já foi estabelecido que o estroma que circunda as neoplasias está diretamente relacionado ao seu comportamento biológico (LIOTTA e KOHN, 2001; DECLERCK et al., 2004; PEREIRA et al., 2005). De fato, o estroma contém tanto elementos celulares quanto não celulares capazes de modificar processos proliferativos e invasivos em células tumorais (WERNERT, 1997; LIOTTA e KOHN, 2001).

A matriz extracelular (MEC) representa o compartimento não celular do estroma circunjacente de neoplasias. É um complexo conjunto composto por várias moléculas estruturais como colágenos, glicoproteínas e proteoglicanas, que forma 0 arcabouço necessário para organização celular apropriada em estruturas tridimensionais. Além disso, a MEC funciona como um reservatório de proteínas ligantes e fatores de crescimento que podem influenciar o destino celular, afetando crescimento, diferenciação, motilidade e viabilidade (DECLERCK et al., 2004; COMOGLIO e TRUSOLINO, 2005; TANZER, 2006).

A lâmina basal, uma fina camada de MEC especializada, é produzida por células na interface epitélio-tecido conjuntivo, e é muito importante em processos 
estruturais como suporte mecânico, polarização celular e compartimentalização de tecidos. Longe de ser uma estrutura inerte, a membrana basal também apresenta participação bastante ativa em funções celulares como morfogênese tecidual, adesão, migração, crescimento e diferenciação celulares (COLOGNATO e YURCHENCO, 2000; BOSMAN e STAMENKOVIC, 2003; YURCHENCO et al., 2004; SUZUKI et al., 2005).

Várias das moléculas que compõem a matriz extracelular e membrana basal apresentam em sua estrutura os chamados sítios matricrípticos ou matricriptinas. Esses sítios, dotados de funções biológicas, estão escondidos dentro da estrutura de proteínas da MEC, e normalmente são expostos através de proteólise, dando origem a fragmentos e peptídeos bioativos (FAISAL KHAN et al., 2002; SCHENK e QUARANTA, 2003; MOTT e WERB, 2004). Durante o processo de invasão, células neoplásicas são capazes de ultrapassar a membrana basal e estroma intersticial, e realizam esse procedimento com a ajuda de enzimas proteolíticas. Nesse momento, essas células tumorais podem ficar expostas a componentes da matriz extracelular, bem como a peptídeos bioativos, passíveis de regular funções celulares (WILSON et al., 1999).

As lamininas são glicoproteínas abundantemente expressas na membrana basal, formadas por três cadeias polipeptídicas $(\alpha, \beta, \gamma)$ (COLOGNATO e YURCHENCO, 2000; MINER e YURCHENCO, 2004; AUMAILLEY et al., 2005; SUZUKI et al., 2005). Essa molécula possui múltiplos sítios matricrípticos vinculados a diferentes atividades biológicas incluindo adesão, migração, diferenciação, angiogênese e secreção de proteases (MALINDA e KLEINMAN, 1996; HOFFMAN et al., 1998; FREITAS e JAEGER, 2002; FREITAS et al., 2004; MORAIS FREITAS et al., 2007; GAMA-DE-SOUZA et al., 2008). A laminina-111 (antiga laminina-1) é a isoforma que apresenta o maior número de sequências biologicamente ativas já identificadas (NOMIZU et al., 1997; NOMIZU et al., 1998). Nosso laboratório já demonstrou que tanto a laminina-111 quanto alguns de seus peptídeos bioativos, como YIGSR, SIKVAV, C16 e AG73 regulam fenótipo e atividades biológicas de linhagens celulares derivadas de carcinoma adenóide cístico (células CAC2) (FRANCA et al., 2001; FREITAS e JAEGER, 2002; CAPUANO e JAEGER, 2004; FREITAS et al., 2004; OLIVEIRA, 2004; FREITAS et al., 2007; MORAIS FREITAS et al., 2007; GAMA-DE-SOUZA, 2008; GAMA-DE-SOUZA et al., 2008). 
AG73, importante peptídeo bioativo da laminina-111, está localizado no domínio globular LG4 da cadeia a1 (NOMIZU et al., 1995; SUZUKI et al., 2005). Por tal motivo, resolvemos primeiramente analisar se carcinoma epidermóide oral expressava a cadeia $\alpha 1$ da laminina. Nossos resultados mostraram que a cadeia $\alpha 1$ está expressa tanto in vivo, em amostras fixadas de carcinoma epidermóide oral, quanto in vitro, em células OSCC. Tomando como base esses achados, tentamos estabelecer um sistema in vitro, reproduzindo os efeitos de AG73 em diferentes eventos do carcinoma epidermóide.

A cadeia $\alpha 1$ da laminina é proeminente expressa in vivo durante os estágios iniciais de embriogênese, mas exibe expressão limitada em tecidos adultos. (SOROKIN et al., 1997; VIRTANEN et al., 2000; SCHEELE et al., 2007). No entanto, células derivadas de carcinomas parecem ser capazes de sintetizar, depositar e utilizar diferentes isoformas de laminina, como a laminina-111 (PATARROYO et al., 2002; ZIOBER et al., 2006). Adicionalmente, células tumorais podem possuir características embrionárias (DIRKS, 2006; LIND et al., 2006). Dessa forma, podemos especular que uma molécula expressa durante a embriogênese, como a cadeia $\alpha 1$ da laminina, possa ser encontrada em diferentes neoplasias.

Estudo que analisou a expressão, através de imunohistoquímica, de cadeias da laminina em neoplasias malignas de várias partes do organismo demonstrou que a cadeia $\alpha 1$ é expressa em tumores de rim, próstata, mama, ovário e pulmão, mas não de língua (MAATTA et al., 2001). Entretanto, nossos achados positivos em relação a expressão da cadeia $\alpha 1$ em carcinomas epidermóides orais repetiram-se consistentemente. Consideramos portanto que este resultado representa uma descoberta interessante em relação ao comportamento de células de carcinoma epidermóide oral.

O padrão de imunolocalização da cadeia $\alpha 1$ da laminina em amostras de carcinoma epidermóide fixadas e incluídas em parafina foi caracterizado por marcação difusa distribuída no citoplasma de células neoplásicas, principalmente nas localizadas em cordões invasivos. Na maioria dos trabalhos que estudam a expressão da laminina-111 e cadeia $\alpha 1$, a marcação imunohistoquímica é mais proeminente na região da membrana basal (GIANNELLI et al., 2001; MAATTA et al., 2001). Todavia, em condições patológicas, como no caso de neoplasias, localização citoplasmática da laminina $\alpha 1$ pode representar síntese e acúmulo dessa molécula, 
que deverá ser posteriormente lançada na matriz extracelular (CHRISTIE et al., 2004).

Um dos fatores mais importantes para crescimento invasivo e metástases é a remodelação da arquitetura da matriz extracelular através de proteólise, mediada principalmente por metaloproteinases da matriz (MMPs) (LYNCH e MATRISIAN, 2002; BJORKLUND e KOIVUNEN, 2005; RUNDHAUG, 2005). Antes se acreditava que as MMPs participavam desse processo simplesmente através da degradação de matriz extracelular. Porém, hoje já se sabe que modificações proteolíticas promovidas por essas enzimas, em moléculas como a laminina, desempenham papel relevante em determinar a exposição de domínios e sítios crípticos presentes em sua estrutura íntegra (GHOSH e STACK, 2000; SCHENK e QUARANTA, 2003; MOTT e WERB, 2004). Como estes sítios não estão expostos na superfície das proteínas, sua ativação exige modificação estrutural, a qual pode ocorrer através de processamento proteolítico (SCHENK e QUARANTA, 2003).

Observarmos em amostras de carcinoma epidermóide fixadas e incluídas em parafina a expressão de MMP9. Essa proteína apresentou-se com marcação difusa distribuída no citoplasma de células neoplásicas, e também no estroma. A imunolocalização de MMP9 ocorreu em locais semelhantes aos da expressão da cadeia $\alpha 1$ da laminina. Desse modo, pode-se inferir que laminina secretada por células neoplásicas do carcinoma epidermóide pode ser processada por MMPs, resultando em formação de fragmentos contendo peptídeos bioativos que podem regular o comportamento biológico das células (DAVIS et al., 2000; FAISAL KHAN et al., 2002; SCHENK e QUARANTA, 2003; MOTT e WERB, 2004).

Verificamos ainda que a cadeia $\alpha 1$ da laminina e MMP9 estavam expressas em linhagem celular derivada de carcinoma epidermóide (células OSCC). A marcação para a cadeia $\alpha 1$ foi observada como pontos distribuídos sobre a membrana celular, uma vez que as amostras não foram permeabilizadas. Esse resultado mostra que a cadeia $\alpha 1$ pode ser produzida por células OSCC e posteriormente secretadas para o meio extracelular, ficando aderida à superfície celular.

Já marcação para MMP9 em células OSCC foi observada como pontos distribuídos no citoplasma das células. Essa molécula também foi observada no 
espaço extracelular, o que pode caracterizar a MMP9 como produto de secreção de células OSCC.

Peptídeos derivados da laminina-111 estão envolvidos em diferentes atividades biológicas, incluindo adesão celular, espraiamento, crescimento, metástase tumoral, crescimento de neuritos e secreção de MMPs (SUZUKI et al., 2005). A sequência YIGSR, localizada na cadeia $\beta 1$, promove adesão celular e migração, além de inibir angiogênese e metástase (GRAF et al., 1987; IWAMOTO et al., 1987; IWAMOTO et al., 1988) PDGSR e F-9 (RYVVLPR) são sequências localizadas na cadeia $\beta 1$ que também promovem adesão celular (CHARONIS et al., 1988; SKUBITZ et al., 1990). SIKVAV, da cadeia $\alpha 1$, está envolvido com adesão celular, proliferação, crescimento de neuritos e de metástases experimentais, formação de ácinos e atividade de protease (TASHIRO et al., 1989; GRANT et al., 1992; NOMIZU et al., 1992; HOFFMAN et al., 1998; FAISAL KHAN et al., 2002; FREITAS et al., 2004; FREITAS et al., 2007).

Em relação ao $A G 73$, estudos comprovaram que esse peptídeo promove adesão de vários tipos celulares, diferenciação acinar de glândulas salivares, crescimento de neuritos e secreção de MMPs (NOMIZU et al., 1995; RICHARD et al., 1996; WEEKS et al., 1998; HOSOKAWA et al., 1999; RIALAS et al., 2000). Esse peptídeo também está relacionado a angiogênese em diferentes sistemas, e pode ter aplicação terapêutica em injúrias isquêmicas (MOCHIZUKI et al., 2007) e em regeneração e engenharia tecidual (MOCHIZUKI et al., 2003; IKEMOTO et al., 2006; HOZUMI et al., 2009).

AG73 tem uma grande relevância em biologia tumoral, e já foi relacionado, entre outros, a metástases em fígado e de células de carcinoma de ovário, bem como a aumento de colonização pulmonar de células de melanoma (NOMIZU et al., 1997; SONG et al., 1997; KIM et al., 1998; NOMIZU et al., 1998; YOSHIDA et al., 2001).

Nossos resultados mostraram que AG73 promove funções biológicas em células derivadas de carcinoma epidermóide oral. Um conjunto de experimentos mostrou que esse peptídeo induziu migração de células OSCC. Dados publicados previamente na literatura mostraram que AG73 promove adesão celular, espraiamento e migração (HOZUMI et al., 2006; GAMA-DE-SOUZA et al., 2008). Migração ativa de células neoplásicas é um requisito para invasão tumoral, e pode 
ser influenciada por substâncias quimiotáticas e construção de vias adesivas (MALINDA e KLEINMAN, 1996; LIOTTA e KOHN, 2001).

Outro processo relevante na progressão tumoral é a degradação da matriz extracelular. Enzimas importantes nesse processo são as MMPs, uma família de mais de 24 endopeptidases frequentemente encontradas em níveis altos em tumores (MOTT e WERB, 2004; COMOGLIO e TRUSOLINO, 2005). A expressão de MMPs pode ser modulada por inúmeros fatores estimuladores ou supressores, os quais são regulados por sinais gerados por receptores, proteínas da matriz extracelular, estresse e mudanças na forma da célula (STERNLICHT e WERB, 2001).

Nossos resultados mostraram que AG73 estimulou atividade invasiva de células OSSC de maneira dose-dependente. Já que a invasão envolve degradação de matriz mediada por MMPs, decidimos explorar o papel de AG73 na regulação de MMPs. O peptídeo induziu aumento dose dependente de MMP9 ativa quando comparado aos controles. Em conjunto, esses resultados sugerem que AG73 regulam invasão de células OSCC através de degradação da matriz induzida por MMP9.

Entre as várias MMPs envolvidas na tumorigênese, estudos vêm mostrando que a MMP9 desempenha papel relevante na progressão tumoral. Expressão aumentada dessas MMPs já foi observada em carcinoma epidermóide (HEISSENBERG et al., 1998; IKEBE et al., 1999; OHASHI et al., 2000) e esse aumento quase sempre vem acompanhado de atividades invasiva e metastática maiores, que levam a uma diminuição da sobrevida do paciente (EGEBLAD e WERB, 2002). Além do mais, tanto as MMPs quanto seus inibidores se mostraram importantes reguladores de crescimento tumoral, participando da regulação sobre o acesso a fatores de crescimento da matriz extracelular, promovendo angiogênese e mantendo um ambiente favorável ao desenvolvimento tumoral (HEISSENBERG et al., 1998; IKEBE et al., 1999; NAGASE e WOESSNER, 1999; RIEDEL et al., 2000; STERNLICHT e WERB, 2001).

Diante dos resultados que mostraram papel funcional de AG73 na migração, invasão e secreção de proteases em células derivadas de carcinoma epidermóide oral humano, resolvemos explorar um pouco os mecanismos regulatórios envolvidos nesses processos. Para isso, analisamos possíveis receptores para este peptídeo em células OSCC. 
Sindecana-1 e integrina $\beta 1$ estão envolvidos nos efeitos mediados por AG73 em outros sistemas (HOFFMAN et al., 1998; YOSHIDA et al., 2001; ENGBRING et al., 2002; SUZUKI et al., 2003; HOZUMI et al., 2006; GAMA-DE-SOUZA et al., 2008). Por tal motivo resolvemos, em uma primeira etapa, verificar se células OSCC expressavam sindecana-1 e integrina $\beta 1$.

Observamos que células OSCC crescidas sobre AG73 exibiram colocalização de sindecana-1 e integrina $\beta 1$, evento que não foi observado em células crescidas sobre o peptídeo controle AG73SX. A partir desses resultados, concluímos que a ligação de AG73 a esses receptores poderia estar relacionada aos eventos induzidos por esse peptídeo em células OSCC.

Mesmo tendo a habilidade de sobreviver sem contato com substratos da matriz extracelular, as células neoplásicas ainda dependem de sinais gerados por integrinas no processo de desenvolvimento da doença (BISSELL e RADISKY, 2001). Além do mais, durante a progressão tumoral, a função das integrinas parece mudar de mediadoras de contatos adesivos estáveis dos hemidesmossomos para promotoras de migração (PATARROYO et al., 2002). Estes dados corroboram o importante papel das integrinas no processo de carcinogênese.

As integrinas desempenham importante papel mediando efeitos da laminina no comportamento celular, incluindo adesão, migração e diferenciação. São autênticos receptores que reconhecem principalmente as cadeias $\alpha$ da laminina e que modulam vias de sinalização intracelular em resposta à ligação com essa molécula (MERCURIO, 1995; PATARROYO et al., 2002). Aumento da expressão de integrinas contendo a subunidade $\beta 1$ em células de carcinoma epidermóide já foi relatado anteriormente na literatura (ZHANG et al., 1996; SHINOHARA et al., 1999), e esse fato pode ser responsável por um aumento de sítios celulares para ligação de laminina e também de seus peptídeos bioativos.

As integrinas podem associar-se a outras proteínas em processos de sinalização celular. Uma das classes de moléculas que cooperam com as integrinas em diversos mecanismos celulares são as sindecanas (CAREY, 1997; BASS et al., 2009). Já foi estabelecido que as sindecanas podem cooperar sinergicamente com integrinas na formação de complexos de adesão, espraiamento celular e migração direcional, e que podem ainda participar da ativação de integrinas (BEAUVAIS et al., 2004; STREULI e AKHTAR, 2009). 
As sindecanas também apresentam sítios de ligação para a molécula de laminina (OKAMOTO et al., 2003), e diversos trabalhos já demonstraram a correlação entre sindecanas, especialmente a sindecana-1, e o peptídeo AG73 (HOFFMAN et al., 1998; ENGBRING et al., 2002; SUZUKI et al., 2003; HOZUMI et al., 2006).

Em uma segunda etapa, para verificar se sindecana-1 e integrina $\beta 1$ estão realmente envolvidas na transdução de sinais gerados por AG73, células OSCC silenciadas para esses dois receptores foram submetidas a ensaios de migração e invasão na presença desse peptídeo. Os resultados mostraram que houve diminuição nos processos de migração e invasão relacionados a AG73 nessas células. A partir dessas observações, podemos sugerir que sindecana-1 e integrina $\beta 1$ podem cooperar com AG73 regulando migração, invasão e atividade de protease de células OSCC.

O conhecimento de efeitos biológicos de peptídeos derivados da laminina como AG73 ainda é fragmentado. Tentamos com este trabalho correlacionar esses efeitos para melhor entender o papel exercido por esse peptídeo no carcinoma epidermóide. Modificações proteolíticas em moléculas de laminina, mediadas por metaloproteinases da matriz, exercem papel relevante na clivagem e liberação de importantes domínios dessa molécula, como o peptídeo AG73 (GHOSH e STACK, 2000; FAISAL KHAN et al., 2002; SCHENK e QUARANTA, 2003; MOTT e WERB, 2004). Após sua liberação, AG73 poderia ligar-se a determinados receptores celulares, como sindecana-1 e integrina $\beta 1$, e estes receptores desencadeariam vias de transdução de sinais modulando motilidade e secreção de MMPs. As MMPs secretadas poderiam então participar da clivagem de laminina presente na matriz pericelular ou liberada pela própria célula, promovendo a liberação de mais fragmentos e peptídeos que estimulariam crescimento e invasividade tumorais.

Baseados em nossos achados experimentais, propomos que o peptídeo AG73 pode interagir com células do carcinoma epidermóide oral através de sindecana-1 e integrina $\beta 1$, promovendo a ativação de vias de sinalização capazes de promover aumento de motilidade, invasão e secreção de MMP9. 


\section{CONCLUSÃO}

Baseados nos resultados dos experimentos realizados, concluímos que:

1) A cadeia $\alpha 1$ da laminina-111 e MMP9 são expressas in vivo e in vitro no carcinoma epidermóide oral.

2) AG73 induz atividades de migração, invasão e secreção de MMP9 nas células OSCC.

3) O estímulo induzido por AG73 é dose-dependente.

4) Células OSCC exibem colocalização dos receptores integrina $\beta 1 \mathrm{e}$ sindecana-1 na presença de AG73.

5) As atividades de migração, invasão e secreção de proteases induzidas por AG73 envolvem participação de integrina $\beta 1$ e sindecana-1. 


\section{REFERÊNCIAS}

ALEXANDROVA, A. Y. Evolution of cell interactions with extracellular matrix during carcinogenesis. Biochemistry Mosc., v. 73, n. 7, p. 733-741, 2008.

ALEXOPOULOU, A. N. et al. Syndecans in wound healing, inflammation and vascular biology. Int. J. Biochem. Cell Biol., v. 39, n. 3, p. 505-528, 2007.

ANDRE, K. et al. Role of alcohol and tobacco in the aetiology of head and neck cancer: a case-control study in the Doubs region of France. Eur. J. Cancer. B. Oral Oncol., v. 31B, n. 5, p. 301-309, 1995.

AUMAILLEY, M. Structure and supramolecular organization of basement membranes. Kidney Int. Suppl., v. 49, p. S4-7, 1995.

AUMAILLEY, M. et al. A simplified laminin nomenclature. Matrix Biol., v. 24, n. 5, p. 326-332, 2005.

AUMAILLEY, M.; SMYTH, N. The role of laminins in basement membrane function. J. Anat., v. 193, p. 1-21, 1998. Pt. 1.

BARNARD, N. A. et al. Oral cancer development in patients with oral lichen planus. J. Oral Pathol. Med., v. 22, n. 9, p. 421-424, 1993.

BASS, M. D. et al. Syndecans shed their reputation as inert molecules. Sci. Signal, v. 2, n. 64, p. pe18, 2009.

BASS, M. D. et al. Syndecan-4-dependent Rac1 regulation determines directional migration in response to the extracellular matrix. J. Cell Biol., v. 177, n. 3, p. 527538, 2007.

BEAUVAIS, D. M. et al. The syndecan-1 ectodomain regulates alphavbeta3 integrin activity in human mammary carcinoma cells. J. Cell Biol., v. 167, n. 1, p. 171-181, 2004.

BEAUVAIS, D. M.; RAPRAEGER, A. C. Syndecan-1-mediated cell spreading requires signaling by alphavbeta3 integrins in human breast carcinoma cells. Exp. Cell Res., v. 286, n. 2, p. 219-232, 2003.

BERGERS, G. et al. Matrix metalloproteinase-9 triggers the angiogenic switch during carcinogenesis. Nat. Cell Biol., v. 2, n. 10, p. 737-744, 2000.

BERNFIELD, M. et al. Biology of the syndecans: a family of transmembrane heparan sulfate proteoglycans. Annu. Rev. Cell Biol., v. 8, p. 365-393, 1992.

${ }^{*}$ De acordo com:

ASSOCIAÇÃO BRASILEIRA DE NORMAS TÉCNICAS. NBR 6023: Informação e documentação: referências: elaboração. Rio de Janeiro, 2002. 
BISSELL, M. J.; RADISKY, D. Putting tumours in context. Nat. Rev. Cancer, v. 1, n. 1, p. 46-54, 2001.

BJORKLUND, M.; KOIVUNEN, E. Gelatinase-mediated migration and invasion of cancer cells. Biochim. Biophys. Acta, v. 1755, n. 1, p. 37-69, 2005.

BOSMAN, F. T. et al. Basement membranes in neoplasia. Prog. Histochem. Cytochem., v. 24, n. 4, p. 1-92, 1992.

BOSMAN, F. T.; STAMENKOVIC, I. Functional structure and composition of the extracellular matrix. J. Pathol., v. 200, n. 4, p. 423-428, 2003.

BOUCHARDY, C. et al. Role of alcohol dehydrogenase 3 and cytochrome P-4502E1 genotypes in susceptibility to cancers of the upper aerodigestive tract. Int. J. Cancer, v. 87, n. 5 , p. $734-740,2000$.

BOUQUOT, J. E.; MECKSTROTH, R. L. Oral cancer in a tobacco-chewing US population--no apparent increased incidence or mortality. Oral Surg. Oral Med. Oral Pathol. Oral Radiol. Endod., v. 86, n. 6, p. 697-706, 1998.

BOYLE, P. et al. Recent advances in the etiology and epidemiology of head and neck cancer. Curr. Opin. Oncol., v. 2, n. 3, p. 539-545, 1990.

BURGESON, R. E. et al. A new nomenclature for the laminins. Matrix Biol., v. 14, n. 3, p. 209-211, 1994.

CALAIS, G. et al. Randomized trial of radiation therapy versus concomitant chemotherapy and radiation therapy for advanced-stage oropharynx carcinoma. J. Natl. Cancer Inst., v. 91, n. 24, p. 2081-2086, 1999.

CALDERWOOD, D. A. et al. The Talin head domain binds to integrin beta subunit cytoplasmic tails and regulates integrin activation. J. Biol. Chem., v. 274, n. 40, p. 28071-28074, 1999.

CAPUANO, A. C.; JAEGER, R. G. The effect of laminin and its peptide SIKVAV on a human salivary gland myoepithelioma cell line. Oral Oncol., v. 40, n. 1, p. 36-42, 2004.

CAREY, D. J. Syndecans: multifunctional cell-surface co-receptors. Biochem. J., v. 327, p. 1-16, 1997. Pt. 1.

CAREY, D. J. et al. Molecular cloning and characterization of $\mathrm{N}$-syndecan, a novel transmembrane heparan sulfate proteoglycan. J. Cell Biol., v. 117, n. 1, p. 191-201, 1992.

CHAMBERS, A. F.; MATRISIAN, L. M. Changing views of the role of matrix metalloproteinases in metastasis. J. Natl. Cancer Inst., v. 89, n. 17, p. 1260-1270, 1997. 
CHARONIS, A. S. et al. A novel synthetic peptide from the B1 chain of laminin with heparin-binding and cell adhesion-promoting activities. J. Cell Biol., v. 107, n. 3, p. 1253-1260, 1988.

CHERESH, D. A. Structural and biologic properties of integrin-mediated cell adhesion. Clin. Lab. Med., v. 12, n. 2, p. 217-236, 1992.

CHERNOUSOV, M. A.; CAREY, D. J. N-syndecan (syndecan 3) from neonatal rat brain binds basic fibroblast growth factor. J. Biol. Chem., v. 268, n. 22, p. 1681016814, 1993.

CHRISTIE, P. E. et al. Increase in laminin expression in allergic airway remodelling and decrease by dexamethasone. Eur. Respir. J., v. 24, n. 1, p. 107-115, 2004.

CIZMECI-SMITH, G. et al. Syndecan-4 is a primary-response gene induced by basic fibroblast growth factor and arterial injury in vascular smooth muscle cells. Arterioscler. Thromb. Vasc. Biol., v. 17, n. 1, p. 172-180, 1997.

COLOGNATO, H.; YURCHENCO, P. D. Form and function: the laminin family of heterotrimers. Dev. Dyn., v. 218, n. 2, p. 213-234, 2000.

COMOGLIO, P. M.; TRUSOLINO, L. Cancer: the matrix is now in control. Nat. Med., v. 11, n. 11, p. 1156-1159, 2005.

COPPOLINO, M. G.; DEDHAR, S. Bi-directional signal transduction by integrin receptors. Int. J. Biochem. Cell Biol., v. 32, n. 2, p. 171-188, 2000.

COUCHMAN, J. R. et al. Syndecans and cell adhesion. Int. Rev. Cytol., v. 207, p. 113-150, 2001.

CURADO, M. P.; HASHIBE, M. Recent changes in the epidemiology of head and neck cancer. Curr. Opin. Oncol., v. 21, n. 3, p. 194-200, 2009.

DAVIS, G. E. et al. Regulation of tissue injury responses by the exposure of matricryptic sites within extracellular matrix molecules. Am. J. Pathol., v. 156, n. 5, p. 1489-1498, 2000.

DE ARCANGELIS, A. et al. Overexpression of laminin alpha1 chain in colonic cancer cells induces an increase in tumor growth. Int. J. Cancer, v. 94, n. 1, p. 44-53, 2001.

DE MELKER, A. A.; SONNENBERG, A. Integrins: alternative splicing as a mechanism to regulate ligand binding and integrin signaling events. Bioessays, $v$. 21, n. 6, p. 499-509, 1999.

DE OLIVEIRA, P. T. et al. The effect of a reconstituted basement membrane (matrigel) on a human salivary gland myoepithelioma cell line. Virchows Arch., v. 439, n. 4, p. 571-578, 2001. 
DE VISSCHER, J. G. et al. Squamous cell carcinoma of the lower lip in renaltransplant recipients. Report of six cases. Int. J. Oral Maxillofac. Surg., v. 26, n. 2, p. 120-123, 1997.

DECLERCK, Y. A. et al. Proteases, extracellular matrix, and cancer: a workshop of the path B study section. Am. J. Pathol., v. 164, n. 4, p. 1131-1139, 2004.

DIRKS, P. B. Cancer: stem cells and brain tumours. Nature, v. 444, n. 7120, p. 687688, 2006.

EGEBLAD, M.; WERB, Z. New functions for the matrix metalloproteinases in cancer progression. Nat. Rev. Cancer, v. 2, n. 3, p. 161-174, 2002.

EISENBERG, E. Oral lichen planus: a benign lesion. J. Oral Maxillofac. Surg., v. 58, n. 11, p. 1278-1285, 2000.

EKBLOM, M. et al. Laminin isoforms and epithelial development. Ann. N. Y. Acad. Sci., v. 857, p. 194-211, 1998.

EKBLOM, P. et al. Expression and biological role of laminin-1. Matrix Biol., v. 22, n. 1, p. 35-47, 2003.

ENGBRING, J. A. et al. The B16F10 cell receptor for a metastasis-promoting site on laminin-1 is a heparan sulfate/chondroitin sulfate-containing proteoglycan. Cancer Res., v. 62, n. 12, p. 3549-3554, 2002.

ENGBRING, J. A. et al. The laminin alpha-1 chain derived peptide, AG73, increases fibronectin levels in breast and melanoma cancer cells. Clin. Exp. Metastasis, v. 25, n. 3, p. 241-252, 2008.

EPSTEIN, J. B. Oral Cancer. In: GREENBERG, M.;GLICK, M. (Ed.). Burket's Oral Medicine. 10. ed. Hamilton: BC Decker Inc, 2003. p. 194-234.

FAISAL KHAN, K. M. et al. Exposure of cryptic domains in the alpha 1-chain of laminin-1 by elastase stimulates macrophages urokinase and matrix metalloproteinase-9 expression. J. Biol. Chem., v. 277, n. 16, p. 13778-13786, 2002.

FEARS, C. Y.; WOODS, A. The role of syndecans in disease and wound healing. Matrix Biol., v. 25, n. 7, p. 443-456, 2006.

FLAITZ, C. M. et al. Intraoral squamous cell carcinoma in human immunodeficiency virus infection. A clinicopathologic study. Oral Surg. Oral Med. Oral Pathol. Oral Radiol. Endod., v. 80, n. 1, p. 55-62, 1995.

FRANCA, C. M. et al. Effect of N-CAM on in vitro invasion of human adenoid cystic carcinoma cells. Oral Oncol., v. 37, n. 8, p. 638-642, 2001.

FRANCESCHI, S. et al. Alcohol and cancers of the upper aerodigestive tract in men and women. Cancer Epidemiol. Biomarkers Prev., v. 3, n. 4, p. 299-304, 1994. 
FREITAS, V. M.; JAEGER, R. G. The effect of laminin and its peptide SIKVAV on a human salivary gland adenoid cystic carcinoma cell line. Virchows Arch., v. 441, n. 6, p. 569-576, 2002.

FREITAS, V. M. et al. Laminin-1 and SIKVAV a laminin-1-derived peptide, regulate the morphology and protease activity of a human salivary gland adenoid cystic carcinoma cell line. Oral Oncol., v. 40, n. 5, p. 483-489, 2004.

FREITAS, V. M. et al. SIKVAV, a laminin alpha1-derived peptide, interacts with integrins and increases protease activity of a human salivary gland adenoid cystic carcinoma cell line through the ERK $1 / 2$ signaling pathway. Am. J. Pathol., v. 171, n. 1, p. 124-138, 2007.

FRISCH, S. M.; RUOSLAHTI, E. Integrins and anoikis. Curr. Opin. Cell Biol., v. 9, n. 5, p. 701-706, 1997.

GAMA-DE-SOUZA, L. N. Peptídeo C16 derivado da laminina regula migração, invasão e secreção de protease em linhagem celular derivada de carcinoma adenóide cístico humano através de integrinas e das vias de sinalização AKT e ERK. 123 f. Tese (Doutorado em Biologia Celular e Tecidual) - Instituto de Ciências Biomédicas, Universidade de São Paulo, São Paulo, 2008.

GAMA-DE-SOUZA, L. N. et al. Adhesion and protease activity in cell lines from human salivary gland tumors are regulated by the laminin-derived peptide AG73, syndecan-1 and beta1 integrin. Matrix Biol., v. 27, n. 5, p. 402-419, 2008.

GHOSH, S.; STACK, M. S. Proteolytic modification of laminins: functional consequences. Microsc. Res. Tech., v. 51, n. 3, p. 238-246, 2000.

GIANCOTTI, F. G.; TARONE, G. Positional control of cell fate through joint integrin/receptor protein kinase signaling. Annu. Rev. Cell Dev. Biol., v. 19, p. 173206, 2003.

GIANNELLI, G. et al. Altered expression of integrins and basement membrane proteins in malignant and pre-malignant lesions of oral mucosa. J. Biol. Regul. Homeost. Agents, v. 15, n. 4, p. 375-380, 2001.

GILLISON, M. L.; SHAH, K. V. Human papillomavirus-associated head and neck squamous cell carcinoma: mounting evidence for an etiologic role for human papillomavirus in a subset of head and neck cancers. Curr. Opin. Oncol., v. 13, n. 3, p. 183-188, 2001.

GINSBERG, M. H. et al. Ligand binding to integrins: common and ligand specific recognition mechanisms. Cell Differ. Dev., v. 32, n. 3, p. 203-213, 1990.

GRAF, J. et al. A pentapeptide from the laminin B1 chain mediates cell adhesion and binds the 67,000 laminin receptor. Biochemistry, v. 26, n. 22, p. 6896-6900, 1987. 
GRANT, D. S. et al. Interaction of endothelial cells with a laminin A chain peptide (SIKVAV) in vitro and induction of angiogenic behavior in vivo. J. Cell. Physiol., v. 153, n. 3, p. 614-625, 1992.

HANDSLEY, M. M.; EDWARDS, D. R. Metalloproteinases and their inhibitors in tumor angiogenesis. Int. J. Cancer, v. 115, n. 6, p. 849-860, 2005.

HARDISSON, D. Molecular pathogenesis of head and neck squamous cell carcinoma. Eur. Arch. Otorhinolaryngol., v. 260, n. 9, p. 502-508, 2003.

HEISSENBERG, M. C. et al. Metalloproteinases and their inhibitors in squamous cell carcinoma of the hypopharynx: indicators of individual tumor aggressiveness. Otolaryngol. Pol., v. 52, n. 5, p. 521-526, 1998.

HOFFMAN, M. P. et al. Cell type-specific differences in glycosaminoglycans modulate the biological activity of a heparin-binding peptide (RKRLQVQLSIRT) from the $\mathrm{G}$ domain of the laminin alpha1 chain. J. Biol. Chem., v. 276, n. 25, p. $22077-$ 22085, 2001.

HOFFMAN, M. P. et al. Laminin-1 and laminin-2 G-domain synthetic peptides bind syndecan-1 and are involved in acinar formation of a human submandibular gland cell line. J. Biol. Chem., v. 273, n. 44, p. 28633-28641, 1998.

HOHENESTER, E.; ENGEL, J. Domain structure and organisation in extracellular matrix proteins. Matrix Biol., v. 21, n. 2, p. 115-128, 2002.

HOSOKAWA, Y. et al. Significant role of laminin-1 in branching morphogenesis of mouse salivary epithelium cultured in basement membrane matrix. Dev. Growth Differ., v. 41, n. 2, p. 207-216, 1999.

HOZUMI, K. et al. Laminin alpha1 chain LG4 module promotes cell attachment through syndecans and cell spreading through integrin alpha2beta1. J. Biol. Chem., v. 281, n. 43, p. 32929-32940, 2006.

HOZUMI, K. et al. Mixed peptide-chitosan membranes to mimic the biological activities of a multifunctional laminin alpha1 chain LG4 module. Biomaterials, v. 30, n. 8, p. 1596-1603, 2009.

HYNES, R. O. Integrins: a family of cell surface receptors. Cell, v. 48, n. 4, p. 549554, 1987.

HYNES, R. O. Integrins: versatility, modulation, and signaling in cell adhesion. Cell, v. 69 , n. 1, p. 11-25, 1992.

HYNES, R. O. Structural biology. Changing partners. Science, v. 300, n. 5620, p. 755-756, 2003.

HYNES, R. O. et al. The diverse roles of integrins and their ligands in angiogenesis. Cold Spring Harb. Symp. Quant. Biol., v. 67, p. 143-153, 2002. 
IKEBE, T. et al. Gelatinolytic activity of matrix metalloproteinase in tumor tissues correlates with the invasiveness of oral cancer. Clin. Exp. Metastasis, v. 17, n. 4, p. 315-323, 1999.

IKEMOTO, S. et al. Laminin peptide-conjugated chitosan membrane: Application for keratinocyte delivery in wounded skin. J. Biomed. Mater. Res. A., v. 79, n. 3, p. 716722, 2006.

INAGAKI, S. et al. Analysis of DNA adducts of acetaldehyde by liquid chromatography-mass spectrometry. J. Chromatogr. A, v. 987, n. 1-2, p. 341-347, 2003.

INSTITUTO NACIONAL DO CÂNCER. Estimativa 2008: Incidência de Câncer no Brasil. Rio de Janeiro: Ministério da Saúde, 2007. 94 p.

IWAMOTO, Y. et al. Synthetic pentapeptide from the B1 chain of laminin promotes B16F10 melanoma cell migration. J. Cell. Physiol., v. 134, n. 2, p. 287-291, 1988.

IWAMOTO, Y. et al. YIGSR, a synthetic laminin pentapeptide, inhibits experimental metastasis formation. Science, v. 238, n. 4830, p. 1132-1134, 1987.

JAEGER, M. M. et al. Effect of spatial arrangement of the basement membrane on cultured pleomorphic adenoma cells. Study by immunocytochemistry and electron and confocal microscopy. Virchows Arch., v. 430, n. 6, p. 467-477, 1997.

JOVANOVIC, A. et al. Tobacco and alcohol related to the anatomical site of oral squamous cell carcinoma. J. Oral Pathol. Med., v. 22, n. 10, p. 459-462, 1993.

KADLER, K. E. et al. Collagen fibril formation. Biochem. J., v. 316, p. 1-11, 1996. Pt. 1.

KADOYA, Y. et al. Laminin alpha1 chain G domain peptide, RKRLQVQLSIRT, inhibits epithelial branching morphogenesis of cultured embryonic mouse submandibular gland. Dev. Dyn., v. 212, n. 3, p. 394-402, 1998.

KADOYA, Y.; YAMASHINA, S. Salivary gland morphogenesis and basement membranes. Anat. Sci. Int., v. 80, n. 2, p. 71-79, 2005.

KANEMOTO, T. et al. Identification of an amino acid sequence from the laminin $A$ chain that stimulates metastasis and collagenase IV production. Proc. Natl. Acad. Sci. U. S. A., v. 87, n. 6, p. 2279-2283, 1990.

KANTAK, S. S.; KRAMER, R. H. E-cadherin regulates anchorage-independent growth and survival in oral squamous cell carcinoma cells. J. Biol. Chem., v. 273, n. 27, p. 16953-16961, 1998.

KATO, M. et al. Cell surface syndecan-1 on distinct cell types differs in fine structure and ligand binding of its heparan sulfate chains. J. Biol. Chem., v. 269, n. 29, p. 18881-18890, 1994. 
$\mathrm{KIM}, \mathrm{C} . \mathrm{W}$. et al. Members of the syndecan family of heparan sulfate proteoglycans are expressed in distinct cell-, tissue-, and development-specific patterns. Mol. Biol. Cell, v. 5, n. 7, p. 797-805, 1994.

$\mathrm{KIM}$, W. H. et al. Laminin-alpha1-chain sequence Leu-GIn-Val-GIn-Leu-Ser-Ile-Arg (LQVQLSIR) enhances murine melanoma cell metastases. Int. J. Cancer, v. 77, n. 4, p. 632-639, 1998.

KURATOMI, Y. et al. Laminin gamma 1 chain peptide, C-16 (KAFDITYVRLKF), promotes migration, MMP-9 secretion, and pulmonary metastasis of B16-F10 mouse melanoma cells. Br. J. Cancer, v. 86, n. 7, p. 1169-1173, 2002.

KUTLESA, S. et al. Developmentally regulated interactions of human thymocytes with different laminin isoforms. Immunology, v. 105, n. 4, p. 407-418, 2002.

LANDIS, S. H. et al. Cancer statistics, 1999. C.A. Cancer J. Clin., v. 49, n. 1, p. 831, 31, 1999.

LEBAKKEN, C. S.; RAPRAEGER, A. C. Syndecan-1 mediates cell spreading in transfected human lymphoblastoid (Raji) cells. J. Cell Biol., v. 132, n. 6, p. 1209$1221,1996$.

LEE, E. J. et al. Characterization of newly established oral cancer cell lines derived from six squamous cell carcinoma and two mucoepidermoid carcinoma cells. Exp. Mol. Med., v. 37, n. 5, p. 379-390, 2005.

LEE, G. et al. Characterization of novel cell lines established from three human oral squamous cell carcinomas. Int. J. Oncol., v. 20, n. 6, p. 1151-1159, 2002.

LEE, M. H.; MURPHY, G. Matrix metalloproteinases at a glance. J. Cell Sci., v. 117, n. 18, p. 4015-4016, 2004.

LEWIN, F. et al. Smoking tobacco, oral snuff, and alcohol in the etiology of squamous cell carcinoma of the head and neck: a population-based case-referent study in Sweden. Cancer, v. 82, n. 7, p. 1367-1375, 1998.

LI, H. et al. Tumor microenvironment: the role of the tumor stroma in cancer. J. Cell. Biochem., v. 101, n. 4, p. 805-815, 2007.

LIND, G. E. et al. Novel epigenetically deregulated genes in testicular cancer include homeobox genes and SCGB3A1 (HIN-1). J. Pathol., v. 210, n. 4, p. 441-449, 2006.

LIOTTA, L. A.; KOHN, E. C. The microenvironment of the tumour-host interface. Nature, v. 411, n. 6835, p. 375-379, 2001.

LYNCH, C. C.; MATRISIAN, L. M. Matrix metalloproteinases in tumor-host cell communication. Differentiation, v. 70, n. 9-10, p. 561-573, 2002.

MAATTA, M. et al. Comparative analysis of the distribution of laminin chains in the basement membranes in some malignant epithelial tumors: the alpha1 chain of 
laminin shows a selected expression pattern in human carcinomas. J. Histochem. Cytochem., v. 49, n. 6, p. 711-726, 2001.

MADSEN, D. H. et al. Extracellular collagenases and the endocytic receptor, urokinase plasminogen activator receptor-associated protein/Endo180, cooperate in fibroblast-mediated collagen degradation. J. Biol. Chem., v. 282, n. 37, p. 2703727045, 2007.

MALI, M. et al. Inhibition of basic fibroblast growth factor-induced growth promotion by overexpression of syndecan-1. J. Biol. Chem., v. 268, n. 32, p. 24215-24222, 1993.

MALI, M. et al. Sequence of human syndecan indicates a novel gene family of integral membrane proteoglycans. J. Biol. Chem., v. 265, n. 12, p. 6884-6889, 1990.

MALINDA, K. M.; KLEINMAN, H. K. The laminins. Int. J. Biochem. Cell Biol., v. 28, n. 9, p. 957-959, 1996.

MAO, Y.; SCHWARZBAUER, J. E. Fibronectin fibrillogenesis, a cell-mediated matrix assembly process. Matrix Biol., v. 24, n. 6, p. 389-399, 2005.

MARASTONI, S. et al. Extracellular matrix: a matter of life and death. Connect. Tissue Res., v. 49, n. 3, p. 203-206, 2008.

MARTIN, G. R.; TIMPL, R. Laminin and other basement membrane components. Annu. Rev. Cell Biol., v. 3, p. 57-85, 1987.

MASHBERG, A. et al. Tobacco smoking, alcohol drinking, and cancer of the oral cavity and oropharynx among U.S. veterans. Cancer, v. 72, n. 4, p. 1369-1375, 1993.

MASHBERG, A. et al. Alcohol as a primary risk factor in oral squamous carcinoma. C.A. Cancer. J. Clin., v. 31, n. 3, p. 146-155, 1981.

MASHBERG, A.; SAMIT, A. M. Early detection, diagnosis, and management of oral and oropharyngeal cancer. C.A. Cancer J. Clin., v. 39, n. 2, p. 67-88, 1989.

MCCAWLEY, L. J.; MATRISIAN, L. M. Matrix metalloproteinases: they're not just for matrix anymore! Curr. Opin. Cell Biol., v. 13, n. 5, p. 534-540, 2001.

MEHROTRA, R.; YADAV, S. Oral squamous cell carcinoma: etiology, pathogenesis and prognostic value of genomic alterations. Indian J. Cancer, v. 43, n. 2, p. 60-66, 2006.

MERCURIO, A. M. Laminin receptors: achieving specificity through cooperation. Trends Cell Biol., v. 5, n. 11, p. 419-423, 1995.

MINER, J. H.; YURCHENCO, P. D. Laminin functions in tissue morphogenesis. Annu. Rev. Cell Dev. Biol., v. 20, p. 255-284, 2004. 
MIRA, E. et al. Secreted MMP9 promotes angiogenesis more efficiently than constitutive active MMP9 bound to the tumor cell surface. J. Cell Sci., v. 117, n. Pt 9, p. 1847-1857, 2004.

MIRANTI, C. K.; BRUGGE, J. S. Sensing the environment: a historical perspective on integrin signal transduction. Nat. Cell Biol., v. 4, n. 4, p. E83-90, 2002.

MOCHIZUKI, M. et al. Laminin-1 peptide-conjugated chitosan membranes as a novel approach for cell engineering. FASEB J., v. 17, n. 8, p. 875-877, 2003.

MOCHIZUKI, M. et al. Angiogenic activity of syndecan-binding laminin peptide AG73 (RKRLQVQLSIRT). Arch. Biochem. Biophys., v. 459, n. 2, p. 249-255, 2007.

MORAIS FREITAS, V. et al. Malignancy-related 67kDa laminin receptor in adenoid cystic carcinoma. Effect on migration and beta-catenin expression. Oral Oncol., v. 43, n. 10, p. 987-998, 2007.

MORK, J. et al. Human papillomavirus infection as a risk factor for squamous-cell carcinoma of the head and neck. N. Engl. J. Med., v. 344, n. 15, p. 1125-1131, 2001.

MOSCATELLI, D. et al. Multiple forms of an angiogenesis factor: basic fibroblast growth factor. Biochimie, v. 70, n. 1, p. 83-87, 1988.

MOTT, J. D.; WERB, Z. Regulation of matrix biology by matrix metalloproteinases. Curr. Opin. Cell Biol., v. 16, n. 5, p. 558-564, 2004.

MOULD, A. P.; HUMPHRIES, M. J. Regulation of integrin function through conformational complexity: not simply a knee-jerk reaction? Curr. Opin. Cell Biol., v. 16, n. 5, p. 544-551, 2004.

NAGASE, H.; WOESSNER, J. F., JR. Matrix metalloproteinases. J. Biol. Chem., v. 274, n. 31, p. 21491-21494, 1999.

NEVILLE, B. W. et al. Patologia Epitelial. In: NEVILLE, B. W., et al (Ed.). Patologia Oral \& Maxilofacial. 2. ed. Rio de Janeiro: Guanabara Koogan, 2004. p. 302-372.

NEVILLE, B. W.; DAY, T. A. Oral cancer and precancerous lesions. C.A. Cancer J. Clin., v. 52, n. 4, p. 195-215, 2002.

NOMIZU, M. et al. Identification of cell binding sites in the laminin alpha 1 chain carboxyl-terminal globular domain by systematic screening of synthetic peptides. J. Biol. Chem., v. 270, n. 35, p. 20583-20590, 1995.

NOMIZU, M. et al. Cell binding sequences in mouse laminin alpha1 chain. J. Biol. Chem., v. 273, n. 49, p. 32491-32499, 1998.

NOMIZU, M. et al. Cell adhesive sequences in mouse laminin beta1 chain. Arch. Biochem. Biophys., v. 378, n. 2, p. 311-320, 2000. 
NOMIZU, M. et al. Identification of cell binding sequences in mouse laminin gamma1 chain by systematic peptide screening. J. Biol. Chem., v. 272, n. 51, p. 3219832205, 1997.

NOMIZU, M. et al. The all-D-configuration segment containing the IKVAV sequence of laminin A chain has similar activities to the all-L-peptide in vitro and in vivo. J. Biol. Chem., v. 267, n. 20, p. 14118-14121, 1992.

NOMIZU, M. et al. Identification of homologous biologically active sites on the Nterminal domain of laminin alpha chains. Biochemistry, v. 40, n. 50, p. 15310-15317, 2001.

OHASHI, K. et al. Increased expression of matrix metalloproteinase 7 and 9 and membrane type 1-matrix metalloproteinase in esophageal squamous cell carcinomas. Cancer, v. 88, n. 10, p. 2201-2209, 2000.

OKAMOTO, O. et al. Normal human keratinocytes bind to the alpha3LG4/5 domain of unprocessed laminin-5 through the receptor syndecan-1. J. Biol. Chem., v. 278, n. 45, p. 44168-44177, 2003.

OLIVEIRA, E. C. Laminina-1 e seu peptídeo AG73 regulando a morfologia e atividade proteolítica de linhagem celular derivada de mioepitelioma humano. 78 f. Dissertação (Mestrado em Biologia Celular e Tecidual) - Instituto de Ciências Biomédicas, Universidade de São Paulo, São Paulo, 2004.

ORGANIZAÇÃO MUNDIAL DE SAÚDE. The Global Burden of Disease: 2004 update. Geneva: WHO Press, 2008. 146 p.

OVERALL, C. M.; LOPEZ-OTIN, C. Strategies for MMP inhibition in cancer: innovations for the post-trial era. Nat. Rev. Cancer., v. 2, n. 9, p. 657-672, 2002.

PAGE-MCCAW, A. et al. Matrix metalloproteinases and the regulation of tissue remodelling. Nat. Rev. Mol. Cell Biol., v. 8, n. 3, p. 221-233, 2007.

PATARROYO, M. et al. Laminin isoforms in tumor invasion, angiogenesis and metastasis. Semin. Cancer Biol., v. 12, n. 3, p. 197-207, 2002.

PELUCCHI, C. et al. Alcohol and tobacco use, and cancer risk for upper aerodigestive tract and liver. Eur. J. Cancer Prev., v. 17, n. 4, p. 340-344, 2008.

PEREIRA, A. L. et al. The role of matrix extracellular proteins and metalloproteinases in head and neck carcinomas: an updated review. Braz. J. Otorhinolaryngol., v. 71, n. 1, p. 81-86, 2005.

PEREIRA, M. C. et al. Histologic subtypes of oral squamous cell carcinoma: prognostic relevance. J. Can. Dent. Assoc., v. 73, n. 4, p. 339-344, 2007.

PIERCE, A. et al. Molecular cloning of the major cell surface heparan sulfate proteoglycan from rat liver. J. Biol. Chem., v. 267, n. 6, p. 3894-3900, 1992. 
PONCE, M. L. et al. Identification of a potent peptide antagonist to an active laminin1 sequence that blocks angiogenesis and tumor growth. Cancer Res., v. 63, n. 16, p. 5060-5064, 2003.

PONCE, M. L.; KLEINMAN, H. K. Identification of redundant angiogenic sites in laminin alpha1 and gamma1 chains. Exp. Cell Res., v. 285, n. 2, p. 189-195, 2003.

PONCE, M. L. et al. An angiogenic laminin site and its antagonist bind through the alpha(v)beta3 and alpha5beta1 integrins. FASEB J., v. 15, n. 8, p. 1389-1397, 2001.

POWELL, S. K.; KLEINMAN, H. K. Neuronal laminins and their cellular receptors. Int. J. Biochem. Cell Biol., v. 29, n. 3, p. 401-414, 1997.

RAPRAEGER, A. et al. The cell surface proteoglycan from mouse mammary epithelial cells bears chondroitin sulfate and heparan sulfate glycosaminoglycans. J. Biol. Chem., v. 260, n. 20, p. 11046-11052, 1985.

RHEINWALD, J. G.; BECKETT, M. A. Defective terminal differentiation in culture as a consistent and selectable character of malignant human keratinocytes. Cell, v. 22, n. 2 Pt 2, p. 629-632, 1980.

RIALAS, C. M. et al. Nitric oxide mediates laminin-induced neurite outgrowth in PC12 cells. Exp. Cell Res., v. 260, n. 2, p. 268-276, 2000.

RICHARD, B. L. et al. Identification of synthetic peptides derived from laminin alpha1 and alpha2 chains with cell type specificity for neurite outgrowth. Exp. Cell Res., v. 228, n. 1, p. 98-105, 1996.

RICHARDSON, A.; PARSONS, J. T. Signal transduction through integrins: a central role for focal adhesion kinase? Bioessays, v. 17, n. 3, p. 229-236, 1995.

RIEDEL, F. et al. Expression of 92-kDa type IV collagenase correlates with angiogenic markers and poor survival in head and neck squamous cell carcinoma. Int. J. Oncol., v. 17, n. 6, p. 1099-1105, 2000.

RUNDHAUG, J. E. Matrix metalloproteinases and angiogenesis. J. Cell Mol. Med., v. 9, n. 2, p. 267-285, 2005.

SALASPURO, V.; SALASPURO, M. Synergistic effect of alcohol drinking and smoking on in vivo acetaldehyde concentration in saliva. Int. J. Cancer, v. 111, n. 4, p. 480-483, 2004.

SANDERSON, R. D.; BERNFIELD, M. Molecular polymorphism of a cell surface proteoglycan: distinct structures on simple and stratified epithelia. Proc. Natl. Acad. Sci. U. S. A., v. 85, n. 24, p. 9562-9566, 1988.

SANDERSON, R. D. et al. Fine structure of heparan sulfate regulates syndecan-1 function and cell behavior. J. Biol. Chem., v. 269, n. 18, p. 13100-13106, 1994. 
SANDERSON, R. D. et al. Enzymatic remodeling of heparan sulfate proteoglycans within the tumor microenvironment: growth regulation and the prospect of new cancer therapies. J. Cell. Biochem., v. 96, n. 5, p. 897-905, 2005.

SASAKI, T. et al. Laminin: the crux of basement membrane assembly. J. Cell Biol., v. 164, n. 7, p. 959-963, 2004.

SAUNDERS, S. et al. Molecular cloning of syndecan, an integral membrane proteoglycan. J. Cell Biol., v. 108, n. 4, p. 1547-1556, 1989.

SCHEELE, S. et al. Laminin isoforms in development and disease. J. Mol. Med., v. 85, n. 8, p. 825-836, 2007.

SCHENK, S.; QUARANTA, V. Tales from the crypt[ic] sites of the extracellular matrix. Trends Cell Biol., v. 13, n. 7, p. 366-375, 2003.

SCHWARTZ, M. A. Integrins, oncogenes, and anchorage independence. J. Cell Biol., v. 139, n. 3, p. 575-578, 1997.

SCULLY, C. et al. Genetic aberrations in oral or head and neck squamous cell carcinoma 3: clinico-pathological applications. Oral Oncol., v. 36, n. 5, p. 404-413, 2000.

SHINOHARA, M. et al. Expression of integrins in squamous cell carcinoma of the oral cavity. Correlations with tumor invasion and metastasis. Am. J. Clin. Pathol., v. 111, n. 1, p. 75-88, 1999.

SHWORAK, N. W. et al. Characterization of ryudocan glycosaminoglycan acceptor sites. J. Biol. Chem., v. 269, n. 33, p. 21204-21214, 1994.

SILVERMAN, S. J. et al. Diagnosis. In: SILVERMAN, S. J. (Ed.). Oral cancer. 4. ed. Hamilton: BC Decker, 1998. p. 41-66.

SILVERMAN, S. J. et al. Tobacco usage in patients with head and neck carcinomas: a follow-up study on habit changes and second primary oral/oropharyngeal cancers. J. Am. Dent. Assoc., v. 106, n. 1, p. 33-35, 1983.

SILVERMAN, S. J.; SHILLITOE, E. F. Etiology and predisposing factors. In: SILVERMAN, S. J. (Ed.). Oral Cancer. 4. ed. Hamilton: BC Decker, 1998. p. 7-24.

SKUBITZ, A. P. et al. Definition of a sequence, RYVVLPR, within laminin peptide F-9 that mediates metastatic fibrosarcoma cell adhesion and spreading. Cancer Res, v. 50, n. 23, p. 7612-7622, 1990.

SONG, S. Y. et al. Liver metastasis formation by laminin-1 peptide (LQVQLSIR)adhesion selected B16-F10 melanoma cells. Int. J. Cancer, v. 71, n. 3, p. 436-441, 1997.

SOROKIN, L. M. et al. Differential expression of five laminin alpha (1-5) chains in developing and adult mouse kidney. Dev. Dyn., v. 210, n. 4, p. 446-462, 1997. 
SQUIER, C. A. The nature of smokeless tobacco and patterns of use. C.A. Cancer J. Clin., v. 38, n. 4, p. 226-229, 1988.

STAMENKOVIC, I. Extracellular matrix remodelling: the role of matrix metalloproteinases. J. Pathol., v. 200, n. 4, p. 448-464, 2003.

STERNLICHT, M. D.; WERB, Z. How matrix metalloproteinases regulate cell behavior. Annu. Rev. Cell Dev. Biol., v. 17, p. 463-516, 2001.

STREULI, C. H.; AKHTAR, N. Signal co-operation between integrins and other receptor systems. Biochem. J., v. 418, n. 3, p. 491-506, 2009.

SUBRAMANIAN, S. V. et al. Regulated shedding of syndecan-1 and -4 ectodomains by thrombin and growth factor receptor activation. J. Biol. Chem., v. 272, n. 23, p. 14713-14720, 1997.

SUGERMAN, P. B.; SHILLITOE, E. J. The high risk human papillomaviruses and oral cancer: evidence for and against a causal relationship. Oral Dis., v. 3, n. 3, p. 130$147,1997$.

SUZUKI, N. et al. Biological activities of homologous loop regions in the laminin alpha chain G domains. J. Biol. Chem., v. 278, n. 46, p. 45697-45705, 2003.

SUZUKI, N. et al. Functional sites in the laminin alpha chains. Connect. Tissue Res., v. 46, n. 3, p. 142-152, 2005.

TAMKUN, J. W. et al. Structure of integrin, a glycoprotein involved in the transmembrane linkage between fibronectin and actin. Cell, v. 46, n. 2, p. 271-282, 1986.

TANZER, M. L. Current concepts of extracellular matrix. J. Orthop. Sci., v. 11, n. 3, p. 326-331, 2006.

TASHIRO, K. et al. A synthetic peptide containing the IKVAV sequence from the A chain of laminin mediates cell attachment, migration, and neurite outgrowth. J. Biol. Chem., v. 264, n. 27, p. 16174-16182, 1989.

TERRANOVA, V. P. et al. Modulation of the metastatic activity of melanoma cells by laminin and fibronectin. Science, v. 226, n. 4677, p. 982-985, 1984.

THOMAS, G. T. et al. Matrix metalloproteinases and oral cancer. Oral Oncol., v. 35, n. 3, p. 227-233, 1999.

THORUP, A. K. et al. Can alterations in integrin and laminin- 5 expression be used as markers of malignancy? APMIS, v. 106, n. 12, p. 1170-1180, 1998.

TIMPL, R.; BROWN, J. C. The laminins. Matrix Biol., v. 14, n. 4, p. 275-281, 1994. 
TIMPL, R. et al. Laminin--a glycoprotein from basement membranes. J. Biol. Chem., v. 254 , n. 19 , p. $9933-9937,1979$.

VIRTANEN, I. et al. Laminin alpha1-chain shows a restricted distribution in epithelial basement membranes of fetal and adult human tissues. Exp. Cell Res., v. 257, n. 2, p. 298-309, 2000.

WEEKS, B. S. et al. Laminin-1 and the RKRLQVQLSIRT laminin-1 alpha1 globular domain peptide stimulate matrix metalloproteinase secretion by PC12 cells. Exp. Cell Res., v. 243, n. 2, p. 375-382, 1998.

WEEKS, B. S. et al. The role of protein kinase $C$ in laminin-mediated neurite outgrowth. Biochem. Biophys. Res. Commun., v. 256, n. 1, p. 98-103, 1999.

WERNER, J. A. et al. The role of matrix metalloproteinases in squamous cell carcinomas of the head and neck. Clin. Exp. Metastasis, v. 19, n. 4, p. 275-282, 2002.

WERNERT, N. The multiple roles of tumour stroma. Virchows Arch., v. 430, n. 6, p. 433-443, 1997.

WILSON, D. F. et al. Oral cancer: role of the basement membrane in invasion. Aust. Dent. J., v. 44, n. 2, p. 93-97, 1999.

WINN, D. M. Smokeless tobacco and cancer: the epidemiologic evidence. C.A. Cancer J. Clin., v. 38, n. 4, p. 236-243, 1988.

WINN, D. M. Diet and nutrition in the etiology of oral cancer. Am. J. Clin. Nutr., v. 61, n. 2, p. 437S-445S, 1995.

WINN, D. M. et al. Snuff dipping and oral cancer among women in the southern United States. N. Engl. J. Med., v. 304, n. 13, p. 745-749, 1981.

WOESSNER, J. F., JR. Matrix metalloproteinases and their inhibitors in connective tissue remodeling. FASEB J., v. 5, n. 8, p. 2145-2154, 1991.

WOESSNER, J. F., JR. MMPs and TIMPs. An historical perspective. Methods Mol. Biol., v. 151, n., p. 1-23, 2001.

WOLF, K. et al. Compensation mechanism in tumor cell migration: mesenchymalamoeboid transition after blocking of pericellular proteolysis. J. Cell Biol., v. 160, n. 2, p. 267-277, 2003.

WOODS, A.; COUCHMAN, J. R. Syndecan 4 heparan sulfate proteoglycan is a selectively enriched and widespread focal adhesion component. Mol. Biol. Cell, v. 5, n. 2, p. 183-192, 1994.

YAMAZAKI, D. et al. Regulation of cancer cell motility through actin reorganization. Cancer Sci., v. 96, n. 7, p. 379-386, 2005. 
YOKOYAMA, F. et al. Bifunctional peptides derived from homologous loop regions in the laminin alpha chain LG4 modules interact with both alpha 2 beta 1 integrin and syndecan-2. Biochemistry, v. 44, n. 28, p. 9581-9589, 2005.

YONEDA, A.; COUCHMAN, J. R. Regulation of cytoskeletal organization by syndecan transmembrane proteoglycans. Matrix Biol., v. 22, n. 1, p. 25-33, 2003.

YOSHIDA, Y. et al. Role of laminin in ovarian cancer tumor growth and metastasis via regulation of Mdm2 and Bcl-2 expression. Int. J. Oncol., v. 18, n. 5, p. 913-921, 2001.

YURCHENCO, P. D. et al. Basement membrane assembly, stability and activities observed through a developmental lens. Matrix Biol., v. 22, n. 7, p. 521-538, 2004.

YURCHENCO, P. D.; WADSWORTH, W. G. Assembly and tissue functions of early embryonic laminins and netrins. Curr. Opin. Cell Biol., v. 16, n. 5, p. 572-579, 2004.

ZHANG, K. et al. Restricted expression and function of laminin 1-binding integrins in normal and malignant oral mucosal keratinocytes. Cell Adhes. Commun., v. 4, n. 3, p. 159-174, 1996.

ZIOBER, A. F. et al. The extracellular matrix in oral squamous cell carcinoma: friend or foe? Head Neck, v. 28, n. 8, p. 740-749, 2006.

ZIOBER, B. L. et al. Adhesive mechanisms regulating invasion and metastasis in oral cancer. Crit. Rev. Oral Biol. Med., v. 12, n. 6, p. 499-510, 2001. 